Investigations

\title{
Chronic Lyme Disease: A Working Case Definition
}

\author{
Raphael B. Stricker and Melissa C. Fesler \\ Union Square Medical Associates, San Francisco, CA, USA
}

\author{
Article history \\ Received: 10-01-2018 \\ Revised: 26-03-2018 \\ Accepted: 26-03-2018 \\ Corresponding Author: \\ Raphael B. Stricker \\ Union Square Medical \\ Associates, San Francisco, CA, \\ USA \\ Email: rstricker@usmamed.com
}

\begin{abstract}
Although Lyme disease is the most common tickborne illness in the USA and Eurasia, the pathophysiology and clinical course of chronic Lyme disease (CLD) have not been formally defined. The purpose of this paper is to present a working case definition of CLD based on analysis of more than 700 peer-reviewed publications. According to this definition, CLD is a multisystem illness with diverse musculoskeletal, neuropsychiatric and/or cardiovascular manifestations that result from ongoing infection with pathogenic members of the Borrelia spirochete complex often associated with other tickborne disease (TBD) pathogens. To qualify for the diagnosis of CLD, patients must have Lyme-compatible symptoms and signs that are either consistently or variably present for six or more months. Two subcategories of CLD include untreated chronic Lyme disease (CLD-U) and chronic Lyme disease following a limited course of antibiotic treatment (CLD-T). The symptom patterns and optimal therapy of CLD require further study.
\end{abstract}

Keywords: Lyme Disease, Borrelia burgdorferi, Tickborne Disease, Chronic Infection

\section{Introduction}

Lyme disease caused by the spirochete Borrelia burgdorferi $(\mathrm{Bb})$ is the most common tickborne illness in the USA and Eurasia (Bacon et al., 2008; CDC, 2017; Sykes and Makiello, 2017; Wormser et al., 2006; Cameron et al., 2014). The Centers for Disease Control and Prevention (CDC) estimates that at least 300,000 new cases of Lyme disease are diagnosed each year in the USA and a recent study projects that at least 232,000 new Lyme disease cases occur annually in Western Europe (CDC, 2017; Sykes and Makiello, 2017). Although $\mathrm{Bb}$ is the best known Borrelia genospecies that causes Lyme disease, other Borrelia genospecies and associated TBD pathogens may cause similar symptoms due to dissemination of the infectious agents (Cameron et al., 2014). Bb and associated pathogens have the capacity to invade a variety of eukaryotic cells and tissues including fibroblasts, synovium, skin, ligaments, cardiac tissue, glial and neuronal cells, endothelial cells, lymph nodes and tonsillar lymphoid tissue (Klempner et al., 1993; Georgilis et al., 1992; Snydman et al., 1986; Häupl et al., 1993; Girschick et al., 1996; Valesova et al., 1989; Nanagara et al., 1996; Aberer et al., 1996; Stanek et al., 1990; de Koning et al.,
1989; Livengood and Gilmore, 2006; Ma et al., 1991; Dorward et al., 1997).

We propose a working case definition of chronic Lyme disease (CLD) based on evidence that $\mathrm{Bb}$ and associated pathogens may cause persistent infection that correlates clinically with invasion of the diverse cells and tissues described above (Cameron et al., 2014; Szer et al., 1991; Borgermans et al., 2014; Oksi et al., 1999; Fallon et al., 2018; Miklossy et al., 2012; Donta, 2003; 1997). The resultant chronic illness may be found in patients with undiagnosed Lyme disease or in patients with an inadequate response to TBD treatment, as outlined below.

\section{Components of CLD}

\section{Length of Infection}

In order to define the chronic form of Lyme disease, it is first necessary to define the minimum duration of the medical condition. Goodman et al. (2013) describe the lack of standardization for the definition of chronic medical diseases. The required duration of chronic illness has ranged from more than three months to more than twelve months (USDHHS, 2010a; Hwang et al., 
2001; Warshaw, 2006; Friedman and Jiang, 2008; Anderson, 2017; USDHHS, 2010b) and some researchers have suggested that the medical condition needs to be permanent to qualify (Bernstein et al., 2003; McKenna and Collins, 2010). In the setting of infectious disease in general, the term "chronic" often implies a minimum duration of six months, and with chronic Pseudomonas and Mycobacterial infections the chronically infecting pathogens may be capable of "evading or subverting the immune response" to "establish chronic infection with a time course of years to decades, often resulting in persistent inflammation and disease" (Pressler et al., 2011; Behar et al., 2014). In the case of TBDs, this process often becomes established and persists after 3-6 months of untreated or inadequately treated infection (Cameron et al., 2014; Donta, 2003; 1997). Therefore we define CLD as persistent TBD infection of at least six months' duration, although we emphasize that treatment should not be withheld for individuals presenting with all the criteria discussed in this study except for the duration. In addition, we recognize other challenges including the often uncertain nature of symptom onset and the variability of musculoskeletal, neuropsychiatric and cardiovascular symptoms and signs induced by TBDs (see section on Clinical Manifestations below).

\section{Vector Exposure}

The primary vectors of Lyme disease are members of the Ixodes genus of ticks. In the USA, Ixodes scapularis transmits disease in the Eastern and Midwestern states and Ixodes pacificus in the West (Wormser et al., 2006; Cameron et al., 2014). The European vector of Lyme disease is $I$. ricinus and the Eurasian vector is $I$. persulcatus (Sykes and Makiello, 2017; Wormser et al., 2006; Cameron et al., 2014). Ixodes ticks have a complex life cycle extending over two to three years. Ticks feed as larvae, nymphs and female adults. Each feeding is an opportunity to acquire TBD pathogens and the nymphal and adult feedings allow for disease transmission. Nymphal ticks transmit disease more often than adults, presumably because their small size increases the likelihood that they will go undetected during feeding (MDH, 2017; Kilpatrick et al., 2017). Ixodes ticks live in wooded, brushy areas and tick exposure may be greatest along trails in the woods and at the fringe area where the woods end (MDH, 2017; Kilpatrick et al., 2017). Ticks may also be found in backyard gardens and on wooden structures (Eisen et al., 2009). Reservoir hosts vary by region and may include mice, chipmunks, shrews, squirrels and other small mammals; humans and domesticated animals are incidental hosts (Rudenko et al., 2011; Oliver et al., 2006). Deer play an important role in tick reproduction and dispersal and migratory birds may transport ticks to regions previously thought to be non-endemic for Lyme disease (Bouchard et al., 2013; Elias et al., 2011; Hubálek, 2004; Scott et al., 2014).

\section{Microbiology}

CLD may be caused by any of the known pathogenic Borrelia genospecies and associated TBD pathogens including Babesia, Anaplasma, Ehrlichia, Rickettsia, Powassan virus and possibly Bartonella. In the USA, Lyme disease is primarily associated with $B$. burgdorferi sensu stricto (Bbss), while in Europe, B. afzelii, $B$. garinii and Bbss are found in the majority of cases (Sykes and Makiello, 2017; Wormser et al., 2006; Cameron et al., 2014). The worldwide distribution and pathogenicity of novel Borrelia genospecies such as $B$. miyamotoi, B. mayonii, B. bissettii, B. kurtenbachii, $B$. andersoni, $B$. americana and others remain to be fully characterized (Sudhindra et al., 2016; Cutler et al., 2017; Golovchenko et al., 2016; Margos et al., 2014; Mattila et al., 2007; Rudenko et al., 2009). Genospecies of Borrelia and strains within a given genospecies differ in their clinical presentations, antigenic profiles and response to host immunity (Tijsse-Klasen et al., 2013; Wang et al., 1999). These differences may limit a clinician's ability to recognize the infection, render some diagnostic tests insensitive and possibly increase the risk of developing CLD ((Tijsse-Klasen et al., 2013; Wang et al., 1999)). The role of associated TBD pathogens in patients with CLD is discussed below.

\section{Laboratory Testing for Lyme Disease}

As the CDC acknowledges, "The Lyme disease surveillance case definition was developed to standardize national public health surveillance and reporting of Lyme disease cases; it is not meant to be used as absolute criteria for clinical diagnosis" (Bacon et al., 2008). Criteria generated for epidemiologic surveillance purposes are often inadequate for the diagnosis of Lyme disease. In fact, the two-tiered testing paradigm of Enzyme-Linked Immunosorbent Assay (ELISA) or Immunofluorescent Assay (IFA) screen and Western blot confirmation is positive in less than $30 \%$ of patients with early Lyme disease and in only $46 \%$ of patients with Lyme disease for more than six weeks (Coulter et al., 2005; Wormser et al., 2008; Engstrom et al., 1995; Ledue et al., 1996; Bacon et al., 2003; Bakken et al., 1997; Trevejo et al., 1999; Nowakowski et al., 2001; Wojciechowska-Koszko et al., 2011; ChmielewskaBadora et al., 2006). Factors contributing to the insensitivity of Lyme disease testing include use of a single laboratory strain of $\mathrm{Bb}$ and omission of significant Borrelia antigens on the Western blot, emphasis on commercial test specificity rather than sensitivity, gender bias in Western blot interpretation and the presence of other TBDs (Dressler et al., 1993; Hilton et al., 1996; 
Cook and Puri, 2016; Stricker and Johnson, 2009). The allegedly high sensitivity of two-tiered testing in late Lyme disease is based on circular reasoning, as discussed in detail elsewhere (Stricker and Johnson, 2016).

Seronegativity is well documented in late Lyme disease (Lawrence et al., 1995; Oksi et al., 1995; Chmielewski et al., 2003). In a study of 41 patients with active $\mathrm{Bb}$ infection shown by positive culture and/or PCR, 63.5\% did not have reactive Lyme serologies despite the fact that $54 \%$ had been symptomatic for over a year (Oksi et al., 1995). The authors concluded that "antibodies to B. burgdorferi often are present in only low levels or are even absent in culture- or PCR-positive patients" who have been suffering for years from symptoms of Lyme disease. In a second study of 32 patients hospitalized for late Lyme disease whose disease activity was confirmed by positive PCR, 56.3\% were seronegative (Chmielewski et al., 2003).

A further serological complication relates to interpretation of IgM seropositivity in the setting of CLD. Animal models and human studies support the presence of an $\mathrm{IgM}$ response in chronic as well as acute $\mathrm{Bb}$ infection (Hastey et al., 2012; Steere et al., 1979; Ma et al., 1992; Craft et al., 1986; Kalish et al., 2001). In the murine model, $\mathrm{Bb}$ has been shown to infect lymph nodes and induce sustained proliferation of B-cells that secrete Bb-specific IgM (Chmielewski et al., 2003). Hastey et al. (2012) describe a "B-cell response that is dominated by IgM secreting cells, both induced early in the lymph nodes and also found later in the bone marrow." Not only do their findings support persistence of an IgM response in chronic disease, but their data "provide strong evidence for the diversion and delay of $\mathrm{B}$-cell responses by $\mathrm{Bb}$, which might help $\mathrm{Bb}$ to establish and maintain persistence." Likewise in humans, according to Steere and colleagues, "The amount of IgM generally rose during exacerbations and fell during remissions. Thus, IgM was an important correlate of clinical disease activity" (Steere et al., 1979). Persistent IgM seroreactivity has been described in other infectious diseases (Racine et al., 2011) and appears to be a significant marker of CLD.

Companion diagnostic testing may be useful for the detection and clinical monitoring of CLD. Examples of TBD-related companion diagnostics include CD57 natural killer cell levels, complement $\mathrm{C} 4 \mathrm{a}$ changes and cytokine/chemokine alterations (Stricker and Winger, 2001; Stricker et al., 2009; Soloski et al., 2014). The utility of this testing in CLD requires further study.

\section{Categories of CLD}

\section{Untreated Chronic Lyme Disease (CLD-U)}

Patients whose exposure was not clearly identified and thus have prolonged untreated infection.
CLD may be the consequence of diagnostic delays, and early recognition of the infection is frequently hindered by the failure to recognize or report a tick bite. For example, one study found that only $14 \%$ of patients recalled a tick bite at the site of an EM rash (Berger, 1989). Thus, while a history of potential exposure to Ixodes ticks is an important element in the definition of CLD, documentation of a known tick bite is not required.

Many patients may also be unaware of their exposure risks and clinicians will need to carefully inquire about potential exposures based on a patient's residential, occupational, recreational and travel history. As stated above, Ixodes ticks prefer wooded or brushy areas and exposure risk is correspondingly high in these areas (Kilpatrick et al., 2017; Eisen et al., 2009). Tick exposure may also occur through contact with reservoir animals or with other incidental tick hosts including deer, birds and pets.

Another problem is the variable incidence of the EM rash, which ranges from 27 to $70 \%$ in Lyme disease studies (Bingham et al., 1995; Stricker and Phillips, 2003). The CDC found that patients lacked an EM rash in $30 \%$ of cases that were diagnosed using the surveillance case definition (Bacon et al., 2008). The recognition of early Lyme disease may be delayed when the hallmark EM rash is absent or misidentified.

\section{Chronic Lyme Disease Following Limited Antibiotic Treatment (CLD-T)}

Patients who were diagnosed with Lyme disease and completed a limited course of antibiotic therapy, but whose symptoms persist.

This category differs from "Post-Treatment Lyme Disease Syndrome" (PTLDS), a research case definition proposed by the Infectious Diseases Society of America (IDSA) that excludes ongoing TBD infection as the cause of persistent CLD symptoms. In contrast, CLD-T requires that patients had been diagnosed with Lyme disease and treated with a limited course of antibiotic therapy (generally $<$ four weeks), but that the treatment regimen was inadequate to resolve the infection and that the symptoms persisted or recurred within six months after completion of treatment without a new tick exposure. Clinicians and researchers have recognized that a substantial portion of patients remain ill following a limited course of antibiotic treatment for Lyme disease (Klempner et al., 2001; Stricker, 2007; Cairns and Godwin, 2005; Aucott et al., 2013a; 2013b).

While a relatively short course of appropriately directed antimicrobials may be adequate for individuals who are treated early in the Lyme disease process, treatment is frequently not curative, raising the possibility of TBD pathogen survival (Fallon et al., 2010; Embers et al., 2004; Cabello et al., 2007; 
Szczpanski and Benach, 1991; Hodzic et al., 2003; Mahmoud, 2012; Sapi et al., 2012; Zhang et al., 1997; Coutte et al., 2009). Persistent TBD infection in animals and humans involves potential roles for multiple mechanisms: (1) Immune evasion via physical seclusion of pathogens within immunologically protected tissue sites such as the central nervous system, joints, eyes, connective tissue and genital tract (Fallon et al., 2010; Embers et al., 2004; Cabello et al., 2007; Szczpanski and Benach, 1991; Hodzic et al., 2003; Mahmoud, 2012; Sapi et al., 2012; Zhang et al., 1997; Coutte et al., 2009); (2) alterations in outer surface protein (Osp) profiles of pathogens through antigenic variation (Zhang et al., 1997; Coutte et al., 2009; Liang et al., 2002; Barbour and Restrepo, 2000; Schwan and Piesman, 2000) and alteration in pathogen morphology (including cell-wall deficient forms, spherocytes, round bodies and biofilm aggregates) (Brorson and Brorson, 1997; Brorson and Brorson, 1998; Miklossy et al., 2008; Mursic et al., 1996; Al-Robaiy et al., 2010; Duray et al., 2005; Kersten et al., 1995; Alban et al., 2000); (3) immune modulation via complement interference, neutrophil and dendritic cell dysfunction and cytokine/chemokine alterations (Kraiczy et al., 2004; Pausa et al., 2003; Kraiczy et al., 2002; Hartiala et al., 2008; Hartiala et al., 2007; Meriläinen et al., 2016; Lazarus et al., 2008; Giambarrolemei et al., 1998); and (4) generation of antibiotic-tolerant "persister cells" in some pathogen populations (Sharma et al., 2015; Feng et al., 2015; 2014).

\section{Clinical Manifestations of CLD}

Lyme disease is a multisystem illness that is often referred to as the "new great imitator" due to the diversity of its clinical manifestations that are reminiscent of syphilis (Cruz et al., 2015; Kursawe, 2002; Fallon et al., 1992; Liegner, 2015; Binalsheikh et al., 2012). The wide spectrum of clinical features can range from an EM rash to severe arthritis, carditis or neuropsychiatric symptoms (Wormser et al., 2006; Cameron et al., 2014). Another clinical feature often associated with this condition is the Jarisch-Herxheimer reaction whereby symptoms increase after exposure to antimicrobials (Bryceson et al., 1972; Vaughan et al., 1994; Zifko et al., 1994; See et al., 2005; Pound and May, 2005; Maloy et al., 1998; Fekade et al., 1996; Butler, 2017). This is a phenomenon associated with the treatment of spirochetal diseases such as syphilis, louse-borne relapsing fever, leptospirosis and Lyme disease (Bryceson et al., 1972; Vaughan et al., 1994; Zifko et al., 1994; See et al., 2005; Pound and May, 2005; Maloy et al., 1998; Fekade et al., 1996; Butler, 2017). Recent studies suggest that the Jarisch-Herxheimer reaction is triggered by rapid uptake of damaged spirochetes by neutrophils and mononuclear cells with release of lipoproteins and pyrogens that increase inflammatory cytokines (Butler, 2017). To date, the complete mechanism of this phenomenon remains undefined.

Since clinical features of Lyme disease may change following exposure to antimicrobials, we have proposed two categories for this working case definition of CLD, as outlined above. For CLD-U, the natural course without antimicrobial intervention has been described by Steere and colleagues in the USA (Steere et al., 1987; Szer et al., 1991). Prior to recognition of the importance of antimicrobial therapy, untreated patients with EM rash displayed the following clinical characteristics over six years of follow-up: $62 \%$ developed intermittent or persistent arthritis; $18 \%$ developed arthralgias; $11 \%$ developed neurologic abnormalities; $4 \%$ developed cardiac complications; 33\% developed fatigue; and 33\% developed other symptoms and signs including headache, stiff neck, morning stiffness, myalgias and abdominal pain (Steere et al., 1987). Further characteristics of CLD-U patients have been described by Wormser et al. (2006) in the IDSA Lyme guidelines. Based on clinical diagnosis with serological confirmation using CDC surveillance criteria, later stages of Lyme disease may feature prominent multisystem symptoms and signs as described above (Bacon et al., 2008 Wormser et al., 2006; Cameron et al., 2014).

In contrast to CLD-U, CLD-T is a term used to describe individuals who have been treated for TBDs with a limited course of antibiotics (generally $<$ four weeks) and within six months develop persistent or recurrent and functionally significant fatigue, musculoskeletal pain, cardiovascular disease and/or neuropsychiatric dysfunction that persists for six months or more (Phillips et al., 2005; Stricker and Johnson, 2012). CLD-T acknowledges the extensive published evidence for persistent TBD infection despite a limited course of antibiotic therapy. In contrast, the research case definition for PTLDS proposed by IDSA includes the following statement: "There is no convincing biologic evidence for the existence of symptomatic chronic B. burgdorferi infection among patients after receipt of recommended treatment regimens for Lyme disease" (Wormser et al., 2006). Based on animal models and human studies, however, we propose that treatment with limited antibiotic regimens may not consistently clear the infection, and we have provided evidence to support potential mechanisms by which this persistent infection occurs (see above). Thus Lyme patients who remain symptomatic following a limited course of antibiotic therapy likely have an ongoing, active TBD infection similar to CLD-U patients. We characterize this group as having CLD-T.

Other conditions that can mimic the clinical presentation of CLD must be ruled out. However, the diagnosis of "idiopathic" conditions such as multiple 
sclerosis, motor neuron disease, fibromyalgia or chronic fatigue syndrome is insufficient to rule out the presence of CLD. We analyzed more than 700 peerreviewed publications featuring symptoms and signs associated with both forms of CLD from a MEDLINE search (Appendix A). From this list, we chose 16 studies that describe symptoms and signs in patients with CLD-U and 13 studies that describe symptoms and signs in patients with CLD-T (Appendix B). In these 29 studies, persistent $\mathrm{Bb}$ infection was documented by culture, PCR and/or microscopy, while other studies without this stringent documentation were excluded.

Table 1: Untreated Chronic Lyme Disease (CLD-U)

\begin{tabular}{|c|c|c|}
\hline Symptom/sign & No. of patients & Category \\
\hline Chest Pain & 1 & Cardiac \\
\hline Fibrillation & 1 & Cardiac \\
\hline Flutter & 1 & Cardiac \\
\hline Murmur & 1 & Cardiac \\
\hline Myocardial Infarction & 1 & Cardiac \\
\hline Myocarditis & 1 & Cardiac \\
\hline Myopericarditis & 1 & Cardiac \\
\hline Muscle Atrophy & 1 & Musculoskelatal \\
\hline Synovitis & 3 & Musculoskelatal \\
\hline Tenosynovitis & 1 & Musculoskelatal \\
\hline Arthralgia (joint pain) & 6 & Musculoskelatal \\
\hline Arthritis & 6 & Musculoskelatal \\
\hline Dactylitis & 1 & Musculoskelatal \\
\hline Joint Warmth & 1 & Musculoskelatal \\
\hline Muscle Weakness & 2 & Musculoskelatal \\
\hline Musculoskeletal Pain & 1 & Musculoskelatal \\
\hline Periorbital Edema & 1 & Musculoskelatal \\
\hline Encephalomyelitis & 1 & Neurologic \\
\hline Paraparesis & 1 & Neurologic \\
\hline Encephalopathy & 1 & Neurologic \\
\hline Neuropathy & 2 & Neurologic \\
\hline Optic Neuritis & 2 & Neurologic \\
\hline Transient Ischemic Attack & 1 & Neurologic \\
\hline Blurred Vision & 2 & Neurologic \\
\hline Eye Pain & 1 & Neurologic \\
\hline Facial Pain & 1 & Neurologic \\
\hline Fatigue & 2 & Neurologic \\
\hline Headaches & 3 & Neurologic \\
\hline Hypesthesia & 1 & Neurologic \\
\hline Memory Difficulties & 1 & Neurologic \\
\hline Photophobia & 1 & Neurologic \\
\hline Progressive Visual Loss & 2 & Neurologic \\
\hline Ptosis & 1 & Neurologic \\
\hline Radicular Pain & 3 & Neurologic \\
\hline Restriction of Visual Field & 1 & Neurologic \\
\hline Tinnitus & 1 & Neurologic \\
\hline Vertigo & 1 & Neurologic \\
\hline Total: 37 & Total: 59 & (16 Studies) \\
\hline \multicolumn{3}{|l|}{ Symptom/Sign Category } \\
\hline Musculoskeletal (\%) & $23 / 59(39)$ & \\
\hline Neuropsychiatric (\%) & $29 / 59$ (49) & \\
\hline Cardiovascular (\%) & $7 / 59(12)$ & \\
\hline
\end{tabular}

Table 2: Chronic Lyme Disease Following Limited Antibiotic Treatment (CLD-T)

\begin{tabular}{|c|c|c|}
\hline Symptom/sign & $\begin{array}{l}\text { No. of } \\
\text { patients }\end{array}$ & Category \\
\hline Muscle Atrophy & 1 & Musculoskelatal \\
\hline Fibromyalgia & 1 & Musculoskelatal \\
\hline Meningismus & 1 & Musculoskelatal \\
\hline Synovitis & 1 & Musculoskelatal \\
\hline Tenosynovitis & 1 & Musculoskelatal \\
\hline Arthralgia (joint pain) & 7 & Musculoskelatal \\
\hline Arthritis & 3 & Musculoskelatal \\
\hline Migratory Pain & 1 & Musculoskelatal \\
\hline Muscle Stiffness & 1 & Musculoskelatal \\
\hline Muscle Weakness & 1 & Musculoskelatal \\
\hline Musculoskeletal Pain & 1 & Musculoskelatal \\
\hline Myalgia & 3 & Musculoskelatal \\
\hline Torticollis & 1 & Musculoskelatal \\
\hline Trigger Finger & 1 & Musculoskelatal \\
\hline Dementia & 1 & Neurologic \\
\hline Parkinsonism & 1 & Neurologic \\
\hline Depressed Corneal Reflexes & 1 & Neurologic \\
\hline Hemiparesis & 1 & Neurologic \\
\hline $\begin{array}{l}\text { Recurrent } \\
\text { encephalomyeloradiculopathy }\end{array}$ & 1 & Neurologic \\
\hline Trigeminal Sensory Neuropathy & 1 & Neurologic \\
\hline Blunted Affect & 1 & Neurologic \\
\hline Cognitive Dysfunction & 3 & Neurologic \\
\hline Cogwheel Rigidity & 1 & Neurologic \\
\hline Confusion & 1 & Neurologic \\
\hline Decreased Central Vision & 1 & Neurologic \\
\hline Decreased Verbal Fluency & 1 & Neurologic \\
\hline Depression & 1 & Neurologic \\
\hline Difficulty Naming Objects & 1 & Neurologic \\
\hline Disorientation & 2 & Neurologic \\
\hline Drooling & 1 & Neurologic \\
\hline Fatigue & 4 & Neurologic \\
\hline Fullness in head & 1 & Neurologic \\
\hline Headaches & 3 & Neurologic \\
\hline Hypalgesia & 1 & Neurologic \\
\hline Hypesthesia & 2 & Neurologic \\
\hline Impaired Judgment & 1 & Neurologic \\
\hline Impaired Swallowing & 1 & Neurologic \\
\hline Memory Difficulties & 3 & Neurologic \\
\hline Numbness & 2 & Neurologic \\
\hline Paresthesias & 3 & Neurologic \\
\hline Perseveration & 1 & Neurologic \\
\hline Poor Concentration & 2 & Neurologic \\
\hline Poor Initiation & 1 & Neurologic \\
\hline Radicular Pain & 1 & Neurologic \\
\hline Tinnitus & 2 & Neurologic \\
\hline Tremors & 1 & Neurologic \\
\hline Vertigo & 1 & Neurologic \\
\hline Total: 47 & Total: 73 & (13 Studies) \\
\hline \multicolumn{3}{|l|}{ Symptom/Sign Category } \\
\hline \multicolumn{3}{|c|}{$24 / 73(33)$} \\
\hline Neuropsychiatric (\%) & \multicolumn{2}{|c|}{$49 / 73(67)$} \\
\hline Cardiovascular (\%) & \multicolumn{2}{|c|}{$0 / 73(0)$} \\
\hline
\end{tabular}


The symptom profiles in patients with persistent $\mathrm{Bb}$ infection are indicative of the protean manifestations of CLD. In our representative sample, patients with CLD-U appeared to have relatively more musculoskeletal and cardiovascular symptoms and signs, while patients with CLD-T appeared to have relatively more neuropsychiatric symptoms and signs (Table 1 and 2). The broader pathology in untreated patients versus more restricted pathology following limited treatment is reminiscent of the immunopathology patterns in untreated versus initially-treated syphilis (Gschnait et al., 1982). However the number of studies with stringent documentation of persistent $\mathrm{Bb}$ infection was too small to draw definitive conclusions about patterns of symptoms and signs in CLD patients. Further comparison of symptom profiles associated with the two forms of CLD is warranted.

\section{Co-Infections}

In both categories of persistent $\mathrm{Bb}$ infection, the presence of other TBD pathogens may complicate the diagnosis and treatment of Lyme disease. Ixodes ticks are known to carry more than 237 types of bacteria and at least 26 viruses (Zhang et al., 2014; Tokarz et al., 2014). Some of these organisms, frequently referred to as co-infections, may alter the manifestations of Lyme disease and make it more difficult to eradicate the spirochete. Known co-infecting organisms include Babesia, Ehrlichia/Anaplasma, Rickettsia and Powassan virus (Hunfeld et al., 2008; Curcio et al., 2016; Thompson et al., 2001; Biggs et al., 2016; Dantas-Torres et al., 2012). Additionally, the evidence supporting tickborne Bartonella infection is growing (Maggi et al., 2012; Podsiad et al., 2003). The interplay of other infectious agents with $\mathrm{Bb}$ may complicate the clinical presentation of Lyme disease and prolong the duration of infection, as noted in animal models (Thomas et al., 2001; Zeidner et al., 2000; Moro et al., 2002). The effect of co-infecting TBD pathogens on the evolution of CLD merits further study in humans.

\section{Functional Impact of CLD}

A community-based study of CLD patients found that the Quality of Life (QoL) of these patients was the same or worse compared to that of individuals with depression, diabetes, heart disease, osteoarthritis and rheumatoid arthritis (Cameron, 2008). Using a CDC metric of health-related QoL, a second survey of more than 5,000 respondents with CLD supported this analysis, revealing that $71.6 \%$ rated their health as fair or poor. The functionality scores of CLD patients were worse than those of other chronic diseases including congestive heart failure, fibromyalgia, post-stroke syndrome, post-myocardial infarction, diabetes and multiple sclerosis (Johnson et al., 2014).
Further support for the adverse health impact of CLD was recently provided by Adrion et al. (2015) Based on retrospective data from medical claims over five years in the USA, 52,795 individuals treated for Lyme disease were compared to 263,975 matched controls with no evidence of TBDs. The study found that as many as $63 \%$ of treated Lyme disease patients had persistent symptoms of CLD and that Lyme disease was associated with $\$ 2,968$ higher total health care costs $(95 \% \mathrm{CI}$ : $\$ 2,807-\$ 3,128, \quad \mathrm{p}<0.001)$ and $87 \%$ more outpatient doctor visits $(95 \%$ CI: $86-89 \%, \mathrm{p}<0.001)$ over a 12 month period compared to TBD-negative controls (Stricker and Johnson, 2016; van den Wijngaard et al., 2017). A more recent study from the Netherlands found that the annual cost of treatment for CLD was $€ 5700$ (about \$6300) per patient or a total of $€ 19.3$ million (\$21 million) per year in that country (Cassarino et al., 2003).

We recognize that there may be other contributing and at times independent causes for persistent symptoms in CLD patients. In essence, not all patients who remain symptomatic after being treated for Lyme disease suffer from an active, ongoing infection. Proposed mechanisms of persistent symptoms include immune dysregulation of various types, tissue injury, infection-induced secondary conditions and unrelated diseases (Cassarino et al., 2003; Middelveen and Stricker, 2016). Based on the clinical evidence, however, we assert that a potentially large number of individuals with CLD are adversely impacted by persistent TBD infection associated with significant functional limitations and financial burdens (Cameron, 2008; Johnson et al., 2014; Adrion et al., 2015; Stricker and Johnson, 2016; van den Wijngaard et al., 2017). We hope that technological advances in the characterization of ongoing TBD infection will improve our ability to deal with this condition.

\section{Clinical Judgment}

Until technological advances provide reliably sensitive and specific diagnostics, some patients will continue to have a diagnosis that remains unclear. Under these circumstances, the value of clinical judgment will remain an important component in treating these individuals. According to the American Medical Association Code of Medical Ethics, the primary responsibilities of clinical medicine are to alleviate patient suffering and prevent disease (AMA, 2017). As previously described by Johnson et al. (2014) and Cameron $(2009 ; 2007)$ patients with CLD are often quite ill and physicians are charged with finding balanced and effective management strategies for such patients.

Uncertainty about a CLD diagnosis may confound clinical decision making, but clinical uncertainty should not exclude that diagnosis. This process 
involves both inclusionary and exclusionary criteria. Patient care is dynamic and clinical judgment requires vigilance in assessing clinical outcomes. As described by Kienle and Kiene, "Clinical judgment is a central element of the medical profession, essential for the performance of the doctor" (Kienle and Kiene, 2011). Thus given the current absence of a "gold standard" test for Lyme disease, it is essential that healthcare providers should consider this condition if symptoms and/or clinical signs occur in patients with a history consistent with CLD, as summarized in the guidelines of the International Lyme and Associated Diseases Society (ILADS) (Cameron et al., 2014).

\section{Proposed Diagnostic Criteria for CLD}

The proposed diagnostic criteria for CLD are shown in Table 3.

Table 3. Proposed Diagnostic Criteria for CLD

The four levels of diagnostic criteria are as follows:

1. Required criteria

2. Strongly supportive criteria (but not required)

3. Supportive criteria

4. Additional criteria

\section{Required criteria}

1. Presence of clinical symptoms and/or signs consistent with Bb infection and/or associated TBDs, as described in Table 1 and 2, that adversely impact patient quality of life.

2. Symptom duration greater than six months, either without antibiotic treatment (CLD-U)* or following a limited course of antibiotic treatment for Lyme disease (CLD-T)**.

3. Exclusion of other medical conditions that can completely account for the clinical presentation. Note that unless another disorder can fully explain the entire spectrum of the clinical presentation, the comorbid condition cannot independently rule out CLD.

II. Strongly supportive criteria

1. Positive culture, molecular testing, or some other technology that directly identifies the presence of Bb spirochetes and/or associated TBD pathogens. $\dagger$

2. Positive serological testing. $\dagger$

a. Fulfills CDC surveillance criteria for Bb-related Western blot testing (Bacon et al., 2008).

b. Fulfills $\mathrm{Ma}$ /Engstrom criteria for seroreactivity with at least $2 / 6$ highly specific Bb-related bands on Western blot (23-25, 31, 34, 39, 41, 83-93) (Cook and Puri, 2016; Stricker and Johnson, 2009; Stricker and Johnson, 2016; Lawrence et al., 1995; Oksi et al., 1995; Chmielewski et al., 2003). Note that this could be either IgG or IgM seroreactivity (Hastey et al., 2012; Steere et al., 1979; Ma et al., 1992; Craft et al., 1986; Kalish et al., 2001).

c. Seropositivity for Bb-associated TBD pathogens.

III. Supportive criteria

1. History of EM rash. Although this clinical sign is diagnostic of Lyme disease, absence of the rash does not rule out $\mathrm{Bb}$ infection.

2. Known or possible tick bite

a. Bite from a disease-carrying tick (often not recognized).

b. Risk of tick exposure

1. Individuals residing in a Lyme-endemic area may be exposed through:

Work, recreation and daily activities

2. Individuals not residing in a Lyme-endemic area may be exposed through:

Travel to endemic areas or expansion of the tick range into previously non-endemic areas

IV. Additional criteria

Response to antibiotic intervention

a. Positive and sustained clinical response to appropriately directed antimicrobials

b. Development of a Jarisch-Herxheimer reaction (Bryceson et al., 1972; Vaughan et al., 1994; Zifko et al., 1994;

See et al., 2005; Pound and May, 2005; Maloy et al., 1998; Fekade et al., 1996; Butler, 2017).

*This diagnosis relies on clinical judgment. The more supportive clinical criteria are met, the greater the likelihood of the diagnosis. This cumulative approach emphasizes the limitations of reliable Lyme disease diagnostic testing at the time of publication, as outlined in the ILADS Lyme guidelines (Cameron et al., 2014)

**This diagnosis requires a history of limited antibiotic treatment for Lyme disease (generally $<$ four weeks) within the previous six months, as outlined in the IDSA Lyme guidelines (Wormser et al., 2006).

$\uparrow$ Testing should be performed by a Clinical Laboratory Improvement Amendments (CLIA)- certified laboratory, but the tests do not need Food and Drug Administration (FDA) approval. 


\section{Conclusion}

This is the first study that provides a working case definition of chronic Lyme disease (CLD) and its subcategories. We propose that CLD is the result of persistent, active infection by pathogenic members of the Borrelia spirochete complex often associated with other TBD pathogens. Infection with these organisms produces a wide array of symptoms and signs that may be expressed in a given individual during the course of the chronic illness (Cameron et al., 2014; Liegner, 2015). Whether due to delayed diagnosis (CLD-U) or as a result of persistence after a limited course of antibiotic treatment (CLD-T), these symptoms and signs may fluctuate but are required to have cumulatively persisted for at least six months.

At this time, clinically available diagnostic testing does not consistently allow for identification of the pathogen(s) affecting individuals with CLD. As such, a hallmark feature of our working case definition is reliance on clinical judgment. This process includes the use of supportive diagnostics, but it does not require laboratory confirmation in light of present technological limitations of TBD testing. We recognize that as diagnostic testing evolves, the ability to define this entity should improve.

We also recognize that other diagnoses may be responsible for symptoms and signs that are similar to CLD and need to be considered in CLD patients. We hope that this outline will provide the clinician with a framework to weigh management options for these often significantly debilitated patients. We also hope to provide additional impetus for public policy to recognize the growing risk of the Lyme disease epidemic. Lastly, we encourage researchers to use the proposed definition of CLD to improve laboratory methodology for identifying patients with this condition and to facilitate the development of new treatment options for CLD patients.

\section{Acknowledgment}

The authors thank Bob Bransfield, Joe Burrascano, Dan Cameron, Jeff Fesler, Bernt-Dieter Huismans, Lorraine Johnson, Marianne Middelveen, Steve Phillips and John Scott for helpful discussion.

\section{Disclosures}

The authors have no financial conflicts to declare. There was no funding source for the study.

\section{Author's Contributions}

Raphael B. Stricker: Conceived the study, researched the data, reviewed the tables and wrote the manuscript.
Melissa C. Fesler: Researched the data, constructed the tables and edited the manuscript.

\section{Ethics}

This article is original and contains unpublished material. The corresponding author confirms that all of the other authors have read and approved the manuscript and there are no ethical issues involved.

\section{References}

Aberer, E., A. Kersten, H. Klade, C. Poitschek and W. Jurecka, 1996. Heterogeneity of Borrelia burgdorferi in the skin. Am. J. Dermatopathol., 18: 571-579.

Adrion, E.R., J.N. Aucott, K.W. Lemke and J.P. Weiner, 2015. Health care costs, utilization and patterns of care following Lyme disease. PLoS ONE, 10: e0116767-e0116767. DOI: 10.1371/journal.pone. 0116767

Alban, P.S., P.W. Johnson and D.R. Nelson, 2000. Serum-starvation-induced changes in protein synthesis and morphology of Borrelia burgdorferi. Microbiology, 146: 119-127.

DOI: 10.1099/00221287-146-1-119

Al-Robaiy, S., H. Dihazi, J.E. Kacza, J. Seeger and J. Schiller et al., 2010. Metamorphosis of Borrelia burgdorferi organsims-RNA, lipid and protein composition in context with the spirochetes' shape. J. Basic Microbiol., 50: S5-S17. DOI: $10.1002 /$ jobm.201000074

AMA, 2017. Code of medical ethics. American Medical Association.

Anderson, G., 2017. Chronic care: making the case for ongoing care. Robert Wood Johnson Foundation, Princeton (NJ).

Aucott, J.N., L.A. Crowder and K.B. Kortte, 2013a. Development of a foundation for a case definition of post-treatment Lyme disease syndrome. Int. J. Infect. Dis., 17: e443-e449.

DOI: 10.1016/j.ijid.2013.01.008

Aucott, J.N., A.W. Rebman, L.A. Crowder and K.B. Kortte, 2013b. Post-treatment Lyme disease syndrome symptomatology and the impact on life functioning: Is there something here? Qual. Life Res., 22: 75-84. DOI: 10.1007/s11136-012-0126-6

Bacon, R.M., B.J. Biggerstaff, M.E. Schriefer, R.D. Gilmore Jr and M.T. Philipp et al., 2003. Serodiagnosis of Lyme disease by kinetic enzymelinked immunosorbent assay using recombinant VlsE1 or peptide antigens of Borrelia burgdorferi compared with 2-tiered testing using whole-cell lysates. J. Infect. Dis., 187: 1187-1187.

DOI: $10.1086 / 374395$ 
Bacon, RM., K.J. Kugeler and P.S. Mead, 2008. Surveillance for lyme disease - United States.

Bakken, L.L., S.M. Callister, P.J. Wand and R.F. Schell, 1997. Interlaboratory comparison of test results for detection of Lyme disease by 516 participants in the Wisconsin State Laboratory of Hygiene/College of American Pathologists Proficiency Testing Program. J. Clin. Microbiol., 35: 537-543.

Barbour, A.G. and B.I. Restrepo, 2000. Antigenic variation in vector-borne pathogens. Emerg. Infect. Dis., 6: 449-457. DOI: 10.3201/eid0605.000502

Behar, S.M., S.M. Carpenter, M.G. Booty, D.L. Barber and P. Jayaraman, 2014. Orchestration of pulmonary $\mathrm{T}$ cell immunity during Mycobacterium tuberculosis infection: immunity interruptus. Semin. Immunol., 26: 559-577.

DOI: $10.1016 /$ j.smim.2014.09.003

Berger, B.W., 1989. Dermatologic manifestations of Lyme disease. Rev. Infect. Dis., 11: S1475-S1481. DOI: 10.1093/clinids/11.Supplement_6.S1475

Bernstein, A.B., E. Hing, A.J. Moss, K.F. Allen and A.B. Siller, 2003. Health care in America: Trends in utilization. Hyattsville (MD): National Center for Health Statistics.

Biggs, H.M., C.B. Behravesh, K.K. Bradley, F.S. Dahlgren and N.A. Drexler et al., 2016. Diagnosis and management of tickborne rickettsial diseases: Rocky Mountain Spotted Fever and other spotted fever group Rickettsioses, Ehrlichioses and Anaplasmosis - United States. MMWR Recomm. Rep., 65: 1-44. DOI: 10.15585/mmwr.rr6502al

Binalsheikh, I.M., D. Griesemer, S. Wang and R. AlvarezAltalef, 2012. Lyme neuroborreliosis presenting as Alice in Wonderland syndrome. Pediatr. Neurol., 46: 185-186. DOI: 10.1016/j.pediatrneurol.2012.01.001

Bingham, P.M., S.L. Galetta, B. Athreya and J. Sladky, 1995. Neurologic manifestations in children with Lyme disease. Pediatrics, 96: 1053-1056.

Borgermans, L., G. Goderis, J. Vandevoorde and D. Devroey, 2014. Relevance of chronic Lyme disease to family medicine as a complex multidimensional chronic disease construct: A systematic review. Int. J. Family Med., 2014: 1-10. DOI: 10.1155/2014/138016

Bouchard, C., P.A. Leighton, G. Beauchamp, S. Nguon and L. Trudel, 2013. Harvested white-tailed deer as sentinel hosts for early establishing Ixodes scapularis populations and risk from vector-borne zoonoses in southeastern Canada. J. Med. Entomol., 50: 384-393. DOI: 10.1603/ME12093

Brorson, O. and S.H. Brorson, 1997. Transformation of cystic forms of Borrelia burgdorferi to normal mobile spirochetes. Infection, 25: 240-246.

DOI: $10.1007 / \mathrm{BF} 01713153$
Brorson, O. and S.H. Brorson, 1998. In vitro conversion of Borrelia burgdorferi to cystic forms in spinal fluid and transformation to mobile spirochetes by incubation in BSK-H medium. Infection, 26: 144-150. DOI: $10.1007 / \mathrm{BF} 02771839$

Bryceson, A.D., K.E. Cooper, D.A. Warrell, P.L. Perine and E.H. Parry, 1972. Studies of the mechanism of the Jarisch-Herxheimer reaction in louse-borne relapsing fever: Evidence for the presence of circulating borrelia endotoxin. Clin. Sci., 43: 343-354. DOI: $10.1042 / \operatorname{cs} 0430343$

Butler, T., 2017. The Jarisch-Herxheimer reaction after antibiotic treatment of spirochetal infections: A review of recent cases and our understanding of pathogenesis. Am. J. Trop. Med. Hyg., 96: 46-52. DOI: 10.4269 /ajtmh.16-0434

Cabello, F.C., H.P. Godfrey and S.A. Newman, 2007. Hidden in plain sight: Borrelia burgdorferi and the extracellular matrix. Trends Microbiol., 15: 350-354. DOI: $10.1016 /$ j.tim.2007.06.003

Cairns, V. and J. Godwin, 2005. Post-Lyme borreliosis syndrome: A meta-analysis of reported symptoms. Int. J. Epidemiol., 34: 1340-1345.

DOI: $10.1093 / \mathrm{ije} /$ dyi129

Cameron, D., 2008. Severity of Lyme disease with persistent symptoms. Insights from a double-blind placebo-controlled clincal trial. Minerva Med., 99: 489-496.

Cameron, D.J., 2007. Consequences of treatment delay in Lyme disease. J. Eval. Clin. Pract., 13: 470-472. DOI: $10.1111 / \mathrm{j} .1365-2753.2006 .00734 . \mathrm{x}$

Cameron, D.J., 2009. Clinical trials validate the severity of persistent Lyme disease symptoms. Med. Hypotheses, 72: 153-156.

DOI: 10.1016/j.mehy.2008.09.030

Cameron, D.J., L.B. Johnson and E.L. Maloney, 2014. Evidence assessments and guideline recommendations in Lyme disease: The clinical management of known tick bites, erythema migrans rashes and persistent disease. Expert Rev. AntiInfect. Ther., 12: 1103-1135. DOI: $10.1586 / 14787210.2014 .940900$

Cassarino, D.S., M.M. Quezado, N.R. Ghatak and P.H. Duray, 2003. Lyme-associated parkinsonism: A neuropathologic case study and review of the literature. Arch Pathol. Lab. Med., 127: 1204-1206.

CDC, 2017. How many people get Lyme disease? Centers for Disease Control and Prevention. Accessed April 12, 2018 at: https://www.cdc.gov/lyme/stats/humancases.html

Chmielewska-Badora, J., E. Cisak, A. Wojcik-Fatla, J. Zwoliński and A. Buczek et al., 2006. Correlation of tests for detection of Borrelia burgdorferi sensu lato infection in patients with diagnosed borreliosis. Ann. Agric. Environ. Med., 13: 307-311. 
Chmielewski, T., J. Fiett, M. Gniadkowski and S. Tylewska-Wierzbanowska, 2003. Improvement in the laboratory recognition of Lyme borreliosis with the combination of culture and PCR methods. Mol. Diagn., 7: 155-162. DOI: 10.1007/BF03260032

Cook, M.J. and B.K. Puri, 2016. Commercial test kits for detection of Lyme borreliosis: A meta-analysis of test accuracy. Int. J. Gen. Med., 9: 427-440.

DOI: $10.2147 /$ IJGM.S122313

Coulter, P., C. Lema, D. Flayhart, A.S. Linhardt and J.N. Aucott et al., 2005. Two-year evaluation of Borrelia burgdorferi culture and supplemental tests for definitive diagnosis of Lyme disease. J. Clin. Microbiol., 43: 5080-5084.

DOI: 10.1128/JCM.43.10.5080-5084.2005

Coutte, L., D.J. Botkin, L. Gao and S.J. Norris, 2009. Detailed analysis of sequence changes occurring during VlsE antigenic variation in the mouse model of Borrelia burgdorferi infection. PLoS Pathog., 5: e1000293-e1000293.

DOI: 10.1371/journal.ppat.1000293

Craft., J., D.K. Fischer, G.T. Shimamoto, A.C. Steere, 1986. Antigens of Borrelia burgdorferi recognized during Lyme disease: appearance of a new immunoglobulin $M$ response and expansion of the immunoglobulin $\mathrm{G}$ response late in the illness. J. Clin. Invest., 78: 934-939.

Cruz, A.I., F.J. Aversano, M.A. Seeley, W.N. Sankar and K.D. Baldwin, 2015. Pediatric Lyme arthritis of the hip: The great imitator? J. Pediatr. Orthop.

Curcio, S.R., L.P. Tria and A.L. Gucwa, 2016. Seroprevalence of Babesia microti in individuals with Lyme disease. Vector Borne Zoonotic Dis., 16: 737-743. DOI: $10.1089 / \mathrm{vbz} .2016 .2020$

Cutler, S.J., E. Ruzic-Sabljic and A. Potkonjak, 2017. Emerging borreliae - expanding beyond lyme borreliosis. Mol. Cell. Probes.,

Dantas-Torres, F., B.B. Chomel and D. Otranto, 2012. Ticks and tick-borne diseases: A One Health perspective. Trends Parasitol., 28: 437-446.

DOI: 10.1016/j.pt.2012.07.003

de Koning, J., J.A. Hoogkamp-Korstanje, M.R. van der Linde and H.J.G.M. Crijns, 1989. Demonstration of spirochetes in cardiac biopsies of patients with Lyme disease. J. Infect. Dis., 160: 150-153. DOI: $10.1093 /$ infdis/160.1.150

Donta, S.T., 1997. Tetracycline therapy for chronic Lyme disease. Clin. Infect. Dis., 25: S52-S56. DOI: $10.1086 / 516171$

Donta, S.T., 2003. Macrolide therapy of chronic Lyme Disease. Med. Sci. Monit., 9: 136-142.

Dorward, D.W., E.R. Fischer and D.M. Brooks, 1997. Invasion and cytopathic killing of human lymphocytes by spirochetes causing Lyme disease. Clin. Infect. Dis., 25: S2-S8. DOI: 10.1086/516169
Dressler, F., J.A. Whalen, B.N. Reinhardt and A.C. Steere, 1993. Western blotting in the serodiagnosis of Lyme disease. J. Infect. Dis., 167: 392-400. DOI: 10.1093/infdis/167.2.392

Duray, P.H., S.R. Yin, Y. Ito, L. Bezrukov and C. Cox et al., 2005. Invasion of human tissue ex vivo by Borrelia burgdorferi. J. Infect. Dis., 191: 1747-1754. DOI: $10.1086 / 429632$

Eisen, L., R.J. Eisen, J. Mun, D.J. Salkeld and R.S. Lane, 2009. Transmission cycles of Borrelia burgdorferi and $B$. bissettii in relation to habitat type in northwestern California. J. Vector Ecol., 34: 81-91.

Elias, S.P., R.P. Smith Jr, S.R. Morris, P.W. Rand and C. Lubelczyk, 2011. Density of Ixodes scapularis ticks on Monhegan Island after complete deer removal: a question of avian importation? J. Vector. Ecol., 36: 11-23. DOI: 10.1111/j.1948-7134.2011.00136.x

Embers, M.E., R. Ramamoorthy and M.T. Philipp, 2004. Survival strategies of Borrelia burgdorferi, the etiologic agent of Lyme disease. Microbes Infect., 6 : 312-318. DOI: 10.1016/j.micinf.2003.11.014

Engstrom, S.M., E. Shoop and R.C. Johnson, 1995. Immunoblot interpretation criteria for serodiagnosis of early Lyme disease. J. Clin. Microbiol., 33: 419-427.

Fallon, B.A., E. Petkova, J.G. Keilp and C.B. Britton, 2018. A reappraisal of the U.S. clinical trials of post-treatment Lyme disease syndrome. Open Neurol. J., 6: 79-87. DOI: $10.2174 / 1874205 \times 01206010079$

Fallon, B.A., E.S. Levin and P.J. Schweitzer, 2010. Hardesty D. Inflammation and central nervous system Lyme disease. Neurobiol. Dis., 37: 534-541. DOI: $10.1016 /$ j.nbd.2009.11.016

Fallon, B.A., J.A. Nields, J.J. Burrascano, K. Liegner and D. DelBene et al., 1992. The neuropsychiatric manifestations of Lyme borreliosis. Psychiatr. Q., 63: 95-117. DOI: 10.1007/BF01064684

Fekade, D., K. Knox, K. Hussein, A. Melka and D.G. Lalloo et al., 1996. Prevention of JarischHerxheimer reaction by treatment with antibodies against tumor necrosis factor alpha. N Engl. J. Med., 335: 311-315. DOI: $10.1056 /$ NEJM199608013350503

Feng, J., P.G. Auwaerter and Y. Zhang, 2015. Drug combinations against Borrelia burgdorferi persisters in vitro: Eradication achieved by using daptomycin, cefoperazone and doxycycline. PLoS One, 10: e0117207-e0117207. DOI: 10.1371 /journal.pone.0117207

Feng, J., T. Wang, W. Shi, S. Zhang and D. Sullivan et al., 2014. Identification of novel activity against Borrelia burgdorferi persisters using an FDA approved drug library. Emerg. Microbes Infect., 3: e49-e49. DOI: 10.1038/emi.2014.53

Friedman, B. and H.J. Jiang, 2008. Elixhauser A. Costly hospital readmissions and complex chronic Illness, 45: 408-21. 
Georgilis, K., M. Peacocke and M.S. Klempner, 1992. Fibroblasts protect the Lyme disease spirochete, Borrelia burgdorferi, from ceftriaxone in vitro. J. Infect. Dis., 166: 440-444.

DOI: $10.1093 /$ infdis/166.2.440

Giambarrolemei, G.H., V.A. Dennis and M.T. Philipp, 1998. Borrelia burgdorferi stimulates the production of interleukin-10 in peripheral blood mononuclear cells from uninfected humans and rhesus monkeys. Infect. Immun., 66: 2691-1697.

Girschick, H.J., H.I. Huppertz, H. Rüssmann, V. Krenn and H. Karch, 1996. Intracellular persistence of Borrelia burgdorferi in human synovial cells. Rheumatol. Int., 16: 125-32.

DOI: $10.1007 / \mathrm{BF} 01409985$

Golovchenko, M., M. Vancová, K. Clark, J.H. Oliver Jr and L. Grubhoffer, 2016. A divergent spirochete strain isolated from a resident of the southeastern United States was identified by multilocus sequence typing as Borrelia bissettii. Parasit. Vectors,

Goodman, R.A., S.F. Posner, E.S. Huang, A.K. Parekh and H.K. Koh, 2013. Defining and measuring chronic conditions: Imperatives for research, policy, program and practice. Prev. Chronic. Dis., 10.

Gschnait, F., E. Schoenwald, B.L. Schmidt and A. Luger, 1982. Laboratory evidence for impaired cellular immunity in different stages of syphilis. J. Invest. Dermatol., 79: 40-41.

DOI: 10.1111/1523-1747.ep12510575

Hartiala, P., J. Hytonen, J. Pelkonen, K. Kimppa and A. West et al., 2007. Transcriptional response of human dendritic cells to Borrelia garnii-defective CD38 and CCR7 expression detected. J. Leukoc Biol., 82: 33-43. DOI: 10.1189/jlb.1106709

Hartiala, P., J. Hytonen, J. Suhonen, O. Leppäranta and H. Tuominen-Gustafsson et al., 2008. Borrelia burgdorferi inhibits human neutrophil functions. Microbes Infect., 10: 60-68.

DOI: $10.1016 /$ j.micinf.2007.10.004

Hastey, C.J., R.A. Elsner, S.W. Barthold and N. Baumgarth, 2012. Delays and diversions mark the development of $\mathrm{B}$ cell responses to Borrelia burgdorferi infection. J. Immunol., 188: 5612-5622. DOI: 10.4049/jimmunol.1103735

Häupl, T., G. Hahn, M. Rittig, A. Krause and C. Schoerner, 1993. Persistence of Borrelia burgdorferi in ligamentous tissue from a patient with chronic Lyme borreliosis. Arthritis Rheum., 36: 1621-1626. DOI: 10.1002/art.1780361118

Hilton, E., J. Devoti and S. Sood, 1996. Recommendation to include OspA and OspB in the new immunoblotting criteria for serodiagnosis of Lyme disease. J. Clin. Microbiol., 34: 1353-1354.
Hodzic, E., S. Feng, K.J. Freer and S.W. Barthold, 2003. Borrelia burgdorferi population dynamics and prototype gene expression during infection of immunocmpetent and immunodeficient mice. Infect. Immun., 71: 5042-5055. DOI: 10.1128/IAI.71.9.5042-5055.2003

Hubálek Z., 2004. An annotated checklist of pathogenic microorganisms associated with migratory birds. J. Wild. Dis., 40: 639-659. DOI: $10.7589 / 0090-3558-40.4 .639$

Hunfeld, K.P., A. Hildebrandt and J.S. Gray, 2008. Babesiosis: Recent insights into an ancient disease. Int. J. Parasitol., 38: 1219-1237. DOI: 10.1016/j.ijpara.2008.03.001

Hwang, W., W. Weller, H. Ireys and G. Anderson, 2001. Out-of-pocket medical spending for care of chronic conditions. Health Aff., 20.

Johnson, L., S. Wilcox, J. Mankoff and R.B. Stricker, 2014. Severity of chronic Lyme disease compared to other chronic conditions: A quality of life survey. Peer J., 2: e322-e322. DOI: 10.7717/peerj.322

Kalish, R.A., G. McHugh, J. Granquist, B. Shea and R. Ruthazer et al., 2001. Persistence of immunoglobulin $\mathrm{M}$ or immunoglobulin $\mathrm{G}$ antibody responses to Borrelia burgdorferi 10-20 years after active Lyme disease. Clin. Infect. Dis., 33: 780-785. DOI: $10.1086 / 322669$

Kersten, A., C. Poitschek, S. Rauch and E. Aberer, 1995. Effects of penicillin, ceftriaxone and doxycycline on morphology of Borrelia burgdorferi. Antimicrob. Agents Chemother., 39: 1127-1133. DOI: 10.1128/AAC.39.5.1127

Kienle, G.S. and H. Kiene, 2011. Clinical judgment and the medical profession. J. Eval. Clin. Pract., 17: 621-627. DOI: 10.1111/j.1365-2753.2010.01560.x

Kilpatrick, A.M., A.D.M. Dobson, T. Levi, D.J. Salkeld and A. Swei, 2017. Lyme disease ecology in a changing world: consensus, uncertainty and critical gaps for improving control. Philos. Trans. R. Soc. Lond B Biol. Sci. PMID: 28438910

Klempner, M.S., L.T. Hu, J. Evans, C.H. Schmid and G.M. Johnson et al., 2001. Two controlled trials of antibiotic treatment in patients with persistent symptoms and a history of Lyme disease. N Engl. J. Med., 345: 85-92. DOI: 10.1056/NEJM200107123450202

Klempner, M.S., R. Noring and R.A. Rogers, 1993. Invasion of human skin fibroblasts by the Lyme disease spirochete, Borrelia burgdorferi. J. Infect. Dis., 167: 1074-10 81. DOI: 10.1093/infdis/167.5.1074

Kraiczy, P., C. Skerka, M. Kirschfink, P.F. Zipfel and V. Brade, 2002. Immune evasion of Borrelia burgdorferi: insufficient killing of the pathogens by complement and antibody. Int. J. Med. Microbil., 291: 141-146. DOI: 10.1016/S1438-4221(02)80027-3 
Kraiczy, P., J. Hellwage, C. Skerka, H. Becker and M. Kirschfink et al., 2004. Complement resistance of Borrelia burgoorferi correlates with the expression of BbCRASP-1, a novel linear plasmid-encoded surface protein that interacts with human factor $\mathrm{H}$ and FHL-1 and is unrelated to Erp proteins. J. Biol. Chem., 279: 2421-2429. DOI: 10.1074/jbc.M308343200

Kursawe, H.K., 2002. Diagnosis and therapy of neuroborreliosis. On the hunt for the "great imitator". MMW Fortschr. Med., 144: 33-36.

Lawrence, C., R.B. Lipton, F.D. Lowy and P.K. Coyle, 1995. Seronegative chronic relapsing neuroborreliosis. Eur. Neurol., 35: 113-117. DOI: 10.1159/000117104

Lazarus, J.J., M.A. Kay, A.L. McCarter and R.M. Wooten, 2008. Viable Borrelia burgdorferi enhances interleukin-10 production and suppresses activation of murine macrophages. Infect. Immun., 76: 1153-1162. DOI: 10.1128/IAI.01404-07

Ledue, T.B., M.F. Collins and W.Y. Craig, 1996. New laboratory guidelines for serologic diagnosis of Lyme disease: evaluation of the two-test protocol. J. Clin. Microbiol., 34: 2343-2350.

Liang, F.T., M.B. Jacobs, L.C. Bowers and M.T. Philipp, 2002. An immune evasion mechanism for spirochetal persistence in Lyme borreliosis. J. Exp. Med., 195: 415-422. DOI: 10.1084/jem.20011870

Liegner, K.B., 2015. In the crucible of chronic lyme disease: Collected writings and associated materials. Xlibris, Library of Congress Control Number 2015911615.

Livengood, J.A. and R.D. Gilmore, 2006. Invasion of human neuronal and glial cells by an infectious strain of Borrelia burgdorferi. Microbes Infect., 8: 2832-2840. DOI: 10.1016/j.micinf.2006.08.014

Ma, B., B. Christen, D. Leung and C. Vigo-Pelfrey, 1992. Serodiagnosis of Lyme borreliosis by Western immunoblot: Reactivity of various significant antibodies against Borrelia burgdorferi. J. Clin. Microbiol., 30: 370-376.

Ma, Y., A. Sturrock and J.J. Weis, 1991. Intracellular localization of Borrelia burgdorferi within human endothelial cells. Infect. Immun., 59: 671-678.

Maggi, R.G., B.R. Mozayeni, E.L. Pultorak, B.C. Hegarty and J.M. Bradley et al., 2012. Bartonella spp. bacteremia and rheumatic symptoms in patients from Lyme disease-endemic region. Emerg. Infect. Dis., 18: 783-791. DOI: 10.3201/eid1805.111366

Mahmoud, A.A., 2012. The challenge of intracellular pathogens. N Engl. J. Med., 326: 761-762. DOI: 10.1056/NEJM199203123261109

Maloy, A.L., R.D. Black and R.J. Segurola, 1998. Lyme disease complicated by the Jarisch-Herxheimer reaction. Emerg. Med., 16: 437-438.

DOI: $10.1016 / \mathrm{S} 0736-4679(98) 00011-0$
Margos, G., J. Piesman, R.S Lane, N.H. Ogden and A. Sing, 2014. Borrelia kurtenbachii sp. nov., a widely distributed member of the Borrelia burgdorferi sensu lato species complex in North America. Int. J. Syst. Evol. Microbiol., 64: 128-130. DOI: $10.1099 /$ ijs.0.054593-0

Mattila, J.T., U.G. Munderloh and T.J. Kurtti, 2007. Phagocytosis of the Lyme disease spirochete, Borrelia burgdorferi, by cells from the ticks, Ixodes scapularis and Dermacentor andersoni, infected with an endosymbiont, Rickettsia peacockii. J. Insect. Sci., 7: 1-58. DOI: 10.1673/031.007.5801

McKenna, M. and J. Collins, 2010. Current Issues and Challenges in Chronic Disease Control. In: Chronic Disease Epidemiology and Control, Remington, P.L., R.C. Brownson and M.V. Wegner (Eds.), American Public Health Association, Washington (DC), pp: 1-24.

MDH, 2017. Blacklegged ticks (Deer Tick, Bear Tick). Minnesota Department of Health.

Meriläinen, L., H. Brander, A. Herranen, A. Schwarzbach and L. Gilbert, 2016. Pleomorphic forms of Borrelia burgdorferi induce distinct immune responses. Microbes Infect., 18: 484-495. DOI: 10.1016/j.micinf.2016.04.002

Middelveen, M.J. and R.B. Stricker, 2016. Morgellons disease: A filamentous borrelial dermatitis. Int. J. Gen. Med., 9: 349-354. DOI: 10.2147/IJGM.S116608

Miklossy, J., S. Donta, K. Mueller, O. Nolte and G. Perry, 2012. Chronic or late Lyme neuroborreliosis: Present and future. Open Neurol. J., 6: 78-78. DOI: $10.2174 / 1874205 \mathrm{X} 01206010078$

Miklossy, J., S. Kasas, A.D. Zurn, S. McCall and S. Yu et al., 2008. Persisting atypical and cystic forms of Borrelia burgdorferi and local inflammation in Lyme neuroborreliosis. J. Neuroinflam., 5: 1-18.

Moro, M.H., O.L. Zegarra-Moro, J. Bjornsson, E.K. Hofmeister and E. Bruinsma et al., 2002. Increased arthritis severity in mice coinfected with Borrelia burgdorferi and Babesia microti. J. Infect. Dis., 186: 428-431. DOI: 10.1086/341452

Mursic, V.P., G. Wanner, S. Reinhardt, B. Wilske and U. Busch et al., 1996. Formation and cultivation of Borrelia burgdorferi spheroplast-L-form variants. Infection, 24: 218-226. DOI: 10.1007/BF01781096

Nanagara, R., P.H. Duray and H.R. Schumacher, 1996. Ultrastructural demonstration of spirochetal antigens in synovial fluid and synovial membrane in chronic Lyme disease: Possible factors contributing to persistence of organisms. Hum. Pathol., 27: 10251034. DOI: 10.1016/S0046-8177(96)90279-8

Nowakowski, J., I. Schwartz, D. Liveris, G. Wang and M.E. Aguero-Rosenfeld et al., 2001. Laboratory diagnostic techniques for patients with early Lyme disease associated with erythema migrans: A comparison of different techniques. Clin. Infect. Dis., 33: 2023-2027. DOI: $10.1086 / 324490$ 
Oksi, J., J. Uksila, M. Marjamäki, J. Nikoskelainen and M.K. Viljanen, 1995. Antibodies against whole sonicated Borrelia burgdorferi spirochetes, 41kilodalton flagellin and P39 protein in patients with PCR- or culture-proven late Lyme borreliosis. J. Clin. Microbiol., 33: 2260-2264.

Oksi, J., M. Marjamaki, J. Nikoskelainen and M.K. Viljanen, 1999. Bowelia Burgorferi Detected by Culture and PCR in Clinical Relapse of Disseminated Lyme Borreliosi. Ann. Med., 31: 225-232. DOI: 10.3109/07853899909115982

Oliver, J., R.G. Means, S. Kogut, M. Prusinski and J.J. Howard, 2006. Prevalence of borrelia burgdorferi in small mammals in new york state. J. Med. Entomol., 43: 924-935. DOI: 10.1093/jmedent/43.5.924

Pausa, M., V. Pellis, M. Cinco, P.G. Giulianini and G. Presani et al., 2003. Serum-resistant strains of Borrelia burgdorferi evade complement-mediated killing by expressing a CD59-like complement inhibitory molecule. J. Immunol., 170: 3214-22. DOI: $10.4049 /$ jimmunol.170.6.3214

Phillips, S.E., J.J. Burrascano, N.S. Harris, L. Johnson and P.V. Smith et al., 2005. Chronic infection in 'post-Lyme borreliosis syndrome'. Int. J. Epidemiol., 34: 1439-1440. DOI: 10.1093/ije/dyi240

Podsiad, E., Y.T. Chmielewski and S. TylewskaWierzbanowska, 2003. Bartonella henselae and Borrelia burgdorferi infections of the central nervous system. Ann. NY Acad. Sci., 990: 404-406. DOI: 10.1111/j.1749-6632.2003.tb07400.x

Pound, M.W. and D.B. May, 2005. Proposed mechanisms and preventative options of JarischHerxheimer reactions. J. Clin. Pharm. Ther., 30: 291-295. DOI: 10.1111/j.1365-2710.2005.00631.x

Pressler, T., C. Bohmova, S. Conway, S. Dumcius and L. Hjelte, 2011. Chronic pseudomonas aeruginosa infection definition: Eurocarecf working group report. J Cystic Fibrosis, 10: S75-S78.

Racine, R., M. McLaughlin, D.D. Jones, S.T. Wittmer and K.C. MacNamara et al., 2011. IgM production by bone marrow plasmablasts contributes to longterm protection against intracellular bacterial infection. J. Immunol., 186: 1011-1021.

DOI: $10.4049 /$ jimmunol.1002836

Rudenko, N., M. Golovchenko, L. Grubhoffer and J.H. Oliver Jr., 2011. Updates on borrelia burgdorferi sensu lato complex with respect to public health. Ticks Tick Borne Dis., 2: 123-128.

DOI: $10.1016 /$ j.ttbdis.2011.04.002

Rudenko, N., M. Golovchenko, T. Lin, L. Gao and L. Grubhoffer et al., 2009. Delineation of a new species of the Borrelia burgdorferi sensu lato complex, Borrelia americana sp. nov. J. Clin. Microbiol., 47: 3875-3880.

DOI: 10.1128/JCM.01050-09
Sapi, E., S.L. Bastian, C.M. Mpoy, S. Scott and A. Rattelle et al., 2012. Characterization of biofilm formation by Borrelia burgdorferi in vitro. PLoS One, 7: e48277-e48277.

DOI: 10.1371 journal.pone.0048277

Schwan, T.G. and J. Piesman, 2000. Temporal changes in outer surface proteins $\mathrm{A}$ and $\mathrm{C}$ of the Lyme disease-associated spirochete, Borrelia burgdorferi, during the chain of infection in ticks and mice. J. Clin. Microbiol., 38: 382-388.

Scott, J.D., J.F. Anderson and L.A. Durden, 2012. Widespread dispersal of borrelia burgdorferi-infected ticks collected from songbirds across canada. J. Parasitol., 98: 49-59. DOI: 10.1645/GE-2874.1

See, S., E.K. Scott and M.W. Levin, 2005. Penicillininduced Jarisch-Herxheimer reaction. Ann. Pharmacother., 39: 2128-2130.

DOI: 10.1345/aph.1G308

Sharma, B., A.V. Brown, N.E. Matluck, L.T. Hu and K. Lewis, 2015. Borrelia burgdorferi, the causative agent of Lyme disease, forms drug-tolerant persister cells. Antimicrob. Agents Chemother., 59: 4616-4624. DOI: 10.1128/AAC.00864-15

Snydman, D.R., D.P. Schenkein, V.P. Berardi, C.C. Lastavica and K.M. Pariser, 1986. Borrelia burgdorferi in joint fluid in chronic Lyme arthritis. Ann. Intern. Med., 104: 798-800.

DOI: 10.7326/0003-4819-104-6-798

Soloski, M.J., L.A. Crowder, L.J. Lahey, C.A. Wagner and W.H. Robinson et al., 2014. Serum inflammatory mediators as markers of human Lyme disease activity. PLoS One, 9: e93243-e93243. DOI: 10.1371/journal.pone.0093243

Stanek, G., J. Klein, R. Bittner and D. Glogar, 1990. Isolation of Borrelia burgdorferi from the myocardium of a patient with long-standing cardiomyopathy. N. Engl. J. Med., 322: 249-252. DOI: 10.1056/NEJM199001253220407

Steere, A.C., J.A. Hardin, S. Ruddy, J.G. Mummaw and S.E. Malawista, 1979. Lyme arthritis: Correlation of serum and cryoglobulin IgM with activity and serum IgG with remission. Arthritis Rheum., 22: 471-483. DOI: 10.1002/art.1780220506

Steere, A.C., R.T. Schoen and E. Taylor, 1987. The clinical evolution of Lyme arthritis. Ann. Intern. Med., 107: 725-731. DOI: 10.7326/0003-4819-107-5-725

Stricker, R.B. and E.E. Winger, 2001. Decreased CD57 lymphocyte subset in patients with chronic Lyme disease. Immunol. Lett., 76: 43-48. DOI: $10.1016 / \mathrm{S} 0165-2478(00) 00316-3$

Stricker, R.B. and L. Johnson, 2009. Gender bias in chronic Lyme disease. J. Womens Health, 18: 1717-1718. DOI: 10.1089/jwh.2009.1657 
Stricker, R.B. and L. Johnson, 2012. Spirochetal 'debris' versus persistent infection in chronic Lyme disease: from semantics to science. Future Microbiol., 7: 1243-1246. DOI: $10.2217 / \mathrm{fmb} .12 .92$

Stricker, R.B. and L. Johnson, 2016. Circular reasoning in CDC Lyme disease test review. Pubmed Commons comment on: Moore A, Nelson C, Molins C, Mead P, Schriefer M. Current guidelines, common clinical pitfalls and future directions for laboratory diagnosis of Lyme disease, United States. Emerg. Infect. Dis., 22: 1169-1177.

Stricker, R.B. and L. Johnson, 2016. Lyme disease: The promise of Big Data, companion diagnostics and precision medicine. Infect. Drug Resist., 9: 215-219. DOI: $10.2147 /$ IDR.S114770

Stricker, R.B. and S.E. Phillips, 2003. Lyme disease without erythema migrans: Cause for concern? Am. J. Med., 115: 72-72. DOI: 10.1016/S0002-9343(03)00244-4

Stricker, R.B., 2007. Counterpoint: Long-term antibiotic therapy improves persistent symptoms associated with Lyme disease. Clin. Infect. Dis., 45: 149-157. DOI: $10.1086 / 518853$

Stricker, R.B., V.R. Savely, N.C. Motanya and P.C. Giclas, 2009. Complement split products $\mathrm{C} 3 \mathrm{a}$ and C4a in chronic Lyme disease. Scand. J. Immunol., 69: 64-69. DOI: 10.1111/j.1365-3083.2008.02191.x

Sudhindra, P., G. Wang, M.E. Schriefer, D. McKenna and J. Zhuge, 2016. Insights into Borrelia miyamotoi infection from an untreated case demonstrating relapsing fever, monocytosis and a positive C6 Lyme serology. Diagn. Microbiol. Infect. Dis., 86: 93-96. DOI: $10.1016 /$ j.diagmicrobio.2016.06.015

Sykes, R.A. and P. Makiello, 2017. An estimate of Lyme borreliosis incidence in Western Europe. J. Public Health, 39: 74-81.

Szczpanski, A. and J.L. Benach, 1991. Lyme borreliosis: Host responses to Borrelia burgdorferi. Microbiol. Rev., 55: 21-34.

Szer, I.S., E. Taylor and A.C. Steere, 1991. The longterm course of Lyme arthritis in children. N. Engl. J. Med., 325: 159-163. DOI: $10.1056 /$ NEJM199107183250304

Thomas, V., J. Anguita, S.W. Barthold and E. Fikrig, 2001. Coinfection with Borrelia burgdorferi and the agent of human granulocytic ehrlichiosis alters murine immune responses, pathogen burden and severity of Lyme arthritis. Infect. Immun., 69: 3359-3371. DOI: 10.1128/IAI.69.5.3359-3371.2001

Thompson, C., A. Spiellman and P. Krause, 2001. Coinfecting deer-associated zoonoses: Lyme disease, babesiosis and ehrlichiosis. Clin. Infect. Dis., 33: 676-685. DOI: 10.1086/322681
Tijsse-Klasen, E., N. Pandak, P. Hengeveld, K. Takumi and M.P. Koopmans et al., 2013. Ability to cause erythema migrans differs between Borrelia burgdorferi sensu lato isolates. Parasite Vectors, 22: 23-23. DOI: 10.1186/1756-3305-6-23

Tokarz, R., S.H. Williams, S. Sameroff, M. Sanchez Leon and K. Jain et al., 2014. Virome analysis of Amblyomma americanum, Dermacentor variabilis and Ixodes scapularis ticks reveals novel highly divergent vertebrate and invertebrate viruses. J. Virol., 88: 11480-11492. DOI: $10.1128 / J V I .01858-14$

Trevejo, R.T., P.J. Krause, V.K. Sikand, M.E. Schriefer and R. Ryan et al., 1999. Evaluation of two-test serodiagnostic method for early Lyme disease in clinical practice. J. Infect. Dis., 179: 931-938. DOI: $10.1086 / 314663$

USDHHS, 2010a. Health, United States, 2010, with special feature on death and dying. Hyattsville (MD): Centers for Disease Control and Prevention, National Center for Health Statistics. US Department of Health and Human Services.

USDHHS, 2010b. Multiple chronic conditions - a strategic framework: Optimum health and quality of life for individuals with multiple chronic conditions. Washington (DC): 2010. US Department of Health and Human Services.

Valesova, M., K. Trnavský, D. Hulínská, S. Alusík and J. Janousek, 1989. Detection of borrelia in the synovial tissue from a patient with lyme borreliosis by electron microscopy. J. Rheumatol., 16: 1502-1505.

van den Wijngaard, C.C., A. Hofhuis, A. Wong, M.G. Harms and G.A. de Wit et al., 2017. The cost of Lyme borreliosis. Eur. J. Public Health, 27: 538-547.

Vaughan, C., C.C. Cronin, E.K. Walsh and M. Whelton, 1994. The Jarisch-Herxheimer reaction in leptospirosis. Postgrad. Med. J., 70: 118-121. DOI: $10.1136 /$ pgmj. 70.820 .118

Wang, G., A.P. van Dam, I. Schwartz and J. Dankert, 1999. Molecular typing of Borrelia burgdorferi sensu lato: Taxonomic, epidemiological and clinical implications. Clin. Microbiol. Rev., 2: 633-653.

Warshaw, G., 2006. Introduction: advances and challenges in care of older people with chronic illness. Generations.

Wojciechowska-Koszko, I., I. Mączyńska, Z. Szych and S. Giedrys-Kalemba, 2011. Serodiagnosis of Borreliosis: Indirect immunofluorescence assay, enzyme-linked immunosorbent assay and immunoblotting. Arch. Immunol. Ther. Exp., 59: 69-77. DOI: $10.1007 / \mathrm{s} 00005-010-0111-0$ 
Wormser, G.P., J. Nowakowski, R.B. Nadelman, P. Visinainer and A. Levin et al., 2008. Impact of clinical variables on Borrelia burgdorferi-specific antibody seropositivity in acute-phase sera from patients in North America with culture-confirmed early Lyme disease. Clin. Vaccine Immunol., 15: 1519-1522. DOI: 10.1128/CVI.00109-08

Wormser, G.P., R.J. Dattwy Ler, E.D. Shapiro, J.J. Halperin and A.C. Steere, 2006. The clinical assessment, treatment and prevention of Lyme disease, human granulocytic Anaplasmosis and Babesiosis: Clinical practice guidelines by the Infectious Diseases Society of America. Clin. Infect. Dis., 43: 1089-1134. DOI: 10.1086/508667

Zeidner, N.S., M.C. Dolan, R. Massung, J. Piesman and D. Fish, 2000. Coinfection with Borrelia burgdorferi and the agent of human granulocytic ehrlichiosis suppresses IL-2 and IFN gamma production and promotes an IL-4 response in $\mathrm{C} 3 \mathrm{H} / \mathrm{HeJ}$ mice. Parasite Immunol., 22: 581-588. DOI: $10.1046 /$ j.1365-3024.2000.00339.x

Zhang, J.R., J.M. Hardham, A.G. Barbour and S.J. Norris, 1997. Antigenic variation in Lyme disease borreliae by promiscuous recombination of VMPlike sequence cassettes. Cell, 89: 275-285. DOI: 10.1016/S0092-8674(00)80206-8

Zhang, X.C., Z.N. Yang, B. Lu, X.F. Ma and C.X. Zhang et al., 2014. The composition and transmission of microbiome in hard tick, Ixodes persulcatus, during blood meal. Ticks Tick Borne Dis., 5: 864-870. DOI: /10.1016/j.ttbdis.2014.07.009

Zifko, U., K. Lindner, D. Wimberger, B. Volc and W. Grisold, 1994. Jarisch-Herxheimer reaction in a patient with neurosyphilis. J. Neurol. Neurosurg. Psychiatry, 57: 865-867.

DOI: $10.1136 /$ jnnp.57.7.865

\section{Appendix A}

\section{Peer-Reviewed Evidence of Persistence of Lyme Disease Spirochete Borrelia burgdorferi and Other Tickborne Diseases}

The following is a list of over 700 peer-reviewed articles that support the evidence for persistence of Lyme and other tickborne diseases. It is organized into different categories-general, neuropsychiatric, dementia and congenital/sexual transmission.

\section{General: Persistence of Borrelia burgdorferi and Other Tickborne Diseases}

1. Abele DC, Anders KH. The many faces and phases of borreliosis. J Am Acad Dermotol 1990; 23:401-410. [chronic Lyme borreliosis].

2. Aberer E, Klade H. Cutaneous manifestations of Lyme borreliosis. Infection 1991; 19: 284-286. [chronic Lyme borreliosis].

3. Aberer E, Breier F, Stanek G, and Schmidt B. Success and failure in the treatment of acrodermatitis chronica atrophicans skin rash. Infection 1996; 24: 85-87.

4. Aberer E, Kersten A, Klade H, Poitschek C, Jurecka W. Heterogeneity of Borrelia burgdorferi in the skin. Am J Dermatopathol 1996; 18(6): 571-519.

5. Aguirre JD, Clark HM, McIlvin M, Vazquez C, Palmere SL, Grab DJ, et al. A manganese-rich environment supports superoxide dismutase activity in a Lyme disease pathogen, Borrelia burgdorferi. J Biol Chem. 2013 Mar 22;288(12):8468-78.

6. Akin E, McHugh Gl, Flavell RA, Fikrig E, Steere AC. The immunoglobulin G (IgG) antibody response to OspA and OspB correlates with severe and prolonged Lyme arthritis and the IgG response to P35 with mild and brief arthritis. Infect Immun 1999; 67: 173-181.

7. Albert S, Schulze J, Riegel H, Brade V. Lyme arthritis in a 12-year-old patient after a latency period of 5 years. Infection 1999; 27(4-5): 286-288.

8. Allred DR. Babesiosis: persistence in the face of adversity. Trends Parasitol. 2003;19:51-55.

9. Al-Robaiy S, Dihazi H, Kacza J, Seeger J, Schiller J, Huster D, et al. Metamorphosis of Borrelia burgdorferi organisms-RNA, lipid and protein composition in context with the spirochete's shape. J Basic Microbiol 2010; 50 (Suppl 1): S5-17.

10. Appel MJG, Allan S, Jacobson RH, Lauderdale TL, Chang YF, Shin SJ, Thomford JW, Todhunter RJ, Summers BA. Experimental Lyme disease in dogs produces arthritis and persistent infection. J Infect Dis 1993; 167: 651-664.

11. Åsbrink E, Hovmark A. Successful cultivation of spirochetes from skin lesions of patients with erythema chronicum migrans, Afzelius and acrodermatis chronica atrophicans. Acta Pathol Microbiol Immunol Sect B 1985; 93: 161-163. 
12. Åsbrink E, Hovmark A, and Olsson I. Clinical manifestations of acrodermatitis chronica atrophicans in 50 Swedish patients. Zentralbl Bakteriol Mikrobiol Hyg A 1986; 26: 253-261.

13. Asch ES, Bujak DI, Weiss M, Peterson MGE, Weinstein A. Lyme Disease: an infectious and postinfectious syndrome. J Rheumatol 1994; 21 (3): 451-461.

14. Bankhead T, Chaconas G. The role of VlsE antigenic variation in the Lyme disease spirochete: persistence through a mechanism that differs from other pathogens. Molecular Microbiology 2007; 65: 1547-1558.

15. Barthold SW, Persing DH, Armstrong AL, Peeples RA. Kinetics of Borrelia burgdorferi dissemination and evolution of disease following intradermal inoculation of mice. Am J Pathol 1991; 139: 263-273.

16. Barthold SW, deSouza MS, Janotka JL, Smith AL, Persing DH. Chronic Lyme borreliosis in the laboratory mouse. Am J Pathol 1993; 143: 951-971.

17. Barthold SW, Hodzic E, Imai DM, Feng S, Yang X, Luft BJ. Ineffectiveness of tigecycline against persistent Borrelia burgdorferi. Antimicrob Agents Chemother 2010; 54(2): 643-651.

18. Barthold SW. Global challenges in diagnosing and managing Lyme disease - closing knowledge gaps. Testimony before House Committee on Foreign Affairs, United States Congress, 17 July 2012. Transcript available at: http://archives.republicans.foreignaffairs.house.gov/112/75161.pdf

19. Battafarano DF, Combs JA, Enzenauer RJ, Fitzpatrick JE. Chronic septic arthritis caused by Borrelia burgdorferi. Clin Orthop 1993;297: 238-241.

20. Baum E, Hue F, Barbour AG. Experimental infections of the reservoir species Peromyscus leuopus with diverse strains of Borrelia burgdorferi, a Lyme disease agent. Mbio. 2012;3: e00434-12.

21. Bayer ME, Zhang L, Bayer MH. Borrelia burgdorferi DNA in the urine of treated patients with chronic Lyme disease symptoms. A PCR study of 97 cases. Infection. 1996; 24: 347-353.

22. Bentas W, Karch H, Huppertz HI. Lyme arthritis in children and adolescents: outcome 12 months after initiation of antibiotic therapy. J Rheumatol. 2000 Aug;27(8):2025-30.

23. Berger TG, Schoerner C, Schell H, Simon M, Schuler G, Röllinghoff M, Gessner A. Two unusual cases of diffuse acrodermatitis chronica atrophicans seronegative for Lyme borreliosis. Eur J Clin Microbiol Infect Dis. 2003 Jun;22(6):392-5.

24. Bergler-Klein J, Ullrich R, Glogar D, Stanek G. [Lyme borreliosis and cardiomyopathy]. Wien Med Wochenschr. 1995;145(7-8):196-8.

25. Berglund J, Stjernberg L, Ornstein K, Tykesson-Joelsson K, Walter H. 5-y follow-up study of patients with neuroborreliosis. Scand. J. Infect. Dis. 2002; 34(6): 421-425.

26. Berndtson K. Review of evidence for immune evasion and persistent infection in Lyme disease. Int J Gen Med 2013; 6: 291-306.

27. Bloom BJ, Wyckoff PM, Meissner HC, Steere AC. Neurocognitive abnormalities in children after classic manifestations of Lyme disease. Pediatric Infect. Dis. J. 1998; 17(3): 189-196.

28. Bradley JF, Johnson RC, Goodman JL. The persistence of spirochetal nucleic acids in active Lyme arthritis. Ann Intern Med 1994;120: 487-489.

29. Bransfield R, Brand S, and Sherr V. Treatment of patients with persistent symptoms and a history of Lyme disease. N Engl Med 2001; 345: 1424-5.

30. Breier F, Khanakah G, Stanek G, Aberer E, Schmidt B, and Tappeiner G. Isolation and polymerase chain reaction typing of Borrelia afzelii from a skin lesion in a seronegative patient with generalized ulcerating bullous lichen sclerosus et atrophicus. Br J Dermatol 2001; 144: 387-392.

31. Bockenstedt LK, Mao J, Hodzic E, Barthold SW, Fish D. Detection of attenuated, non-infectious spirochetes in Borrelia burgdorferi-infected mice after antibiotic treatment. J Infect Dis 2002; 186: 1430-1437.

32. Bockenstedt LK, Gonzalez DG, Hamberman AM, Belperron A. Spirochete antigens persist near cartilage after murine Lyme borreliosis therapy. J Clin Invest 2012;122: 2652-2660.

33. Borgermans L, Goderis G, Vandevoorde J, Devroey D. Relevance of chronic Lyme disease to family medicine as a complex multidimensional chronic disease construct: A systematic review. Int J Family Med. 2014;2014:138016.

34. Bransfield R, Brand S, Sherr V. Treatment of patients with persistent symptoms and a history of Lyme disease. N Engl J Med. 2001 Nov 8;345(19):1424-5.

35. Breier F, Kkhkanakah G, Stanek G, Kunz G, Aberer E, Schmidt B, Tappeiner G. Isolation and polymerase chain reaction of Borrelia afzelii from a skin lesion in a seronegative patient with generalized ulcereating bullous lichen sclerosus et atrophicus. Br J Dermatol 2001; 144: 387-392.

36. Brorson O, Brorson S-H. Transformation of cystic forms of Borrelia burgdorferi to normal mobile spirochetes. Infection. 1997; 25: 240-246.

37. Brorson O, Brorson S. In vitro conversion of Borrelia burgdorferi to cystic forms in spinal fluid, and transformation to mobile spirochetes by incubation in BSK-H medium. Infection. 1998; 26: 144-150. 
38. Brorson O, Brorson SH. An in vitro study of the susceptibility of mobile and cystic forms of Borrelia burgdorferi to metronidazole. APMIS 1999; 107: 566-576.

39. Brorson O, Brorson SH. An in vitro study of the susceptibility of mobile and cystic forms of Borrelia burgdorferi to tinidazole. Int Microbiol 2004; 7: 139-142.

40. Brorson O, Brorson SH. An in vitro study of the activity of telithromycin against mobile and cystic forms of Borrelia afzelii. Infection 2006; 34: 26-28.

41. Brorson O, Brorson SH, Scythes J, MacAllister J, Wier A, and Margulis L. Destruction of spirochete Borrelia burgdorferi round-body propagules by the antibiotic tigecycline. Proc Natl Acad Sci USA 2009; 106: 18656-61

42. Brown JP, Zachary JF, Teuscher C, Weis JJ, and Wooten M. Dual role of interleukin-10 in murine Lyme disease: regulation of arthritis severity and host defense. Infect Immun 1999; 67: 5142-5150.

43. Butler T. The Jarisch-Herxheimer reaction after antibiotic treatment of spirochetal infections: A review of recent cases and our understanding of pathogenesis. Am J Trop Med Hyg. 2017 Jan 11;96(1):46-52.

44. Cabello FC, Godfrey HP, and Newman SA. Hidden in plain sight: Borrelia burgdorferi and the extracellular matrix. Trends in Microbiology 2007; 15: 350-354.

45. Cadavid D, O’Neill T, Schaefer H, Pachner AR. Localization of Borrelia burgdorferi in the nervous system and organs in a nonhuman primate model of Lyme disease. Lab Invest 2000; 80: 1043-1054.

46. Cadavid D, Bai Y, Hodzic E, Narayan K, Barthold SW, Pachner AR. Cardiac involvement in non-human primates infected with the Lyme disease spirochete Borrelia burgdorferi. Lab Invest 2004; 84: 1439-1450.

47. Cameron D, Gaito A, Harris N, Bach G, Bellovin S, Bock K, et al. Evidence-based guidelines for the management of Lyme disease. Expert Rev Anti-Infect. Ther 2004; 2 (Suppl. 1), S1-S13.

48. Cameron DJ. Generalizability in two clinic trials of Lyme disease. Epidemiol Perspect Innov. 2006 Oct 17;3:12.

49. Cameron D. Severity of Lyme disease with persistent symptoms. Insights from a double-blind placebo-controlled clinical trial. Minerva Med 2008; 99: 489-496.

50. Cameron DJ. Insufficient evidence to deny antibiotic treatment to chronic Lyme disease patients. Med Hypotheses 2009 Jun;72(6):688-91.

51. Cameron DJ. Proof that chronic Lyme disease exists. Interdiscip Perspect Infect Dis. 2010;2010:876450.

52. Cameron DJ. Consequences of treatment delay in Lyme disease. J Eval Clin Pract. 2007 Jun;13(3):470-2.

53. Chancellor MB, McGinnis DE, Shenot PJ, Kiilholma P, Hirsch IH. Urinary dysfunction in Lyme disease. J Urol 1993; 149: 26-30.

54. Chang YK, Ku YW, Chang CF, Chang CD, McDonough SP, Divers T, Pough M, Torres A. Antibiotic treatment of experimentally Borrelia burgdorferi-infected ponies. Vet Microbiol 2005; 107: 285-294.

55. Chao L-L, Lu C-F, and Shih C-M. Molecular detection and genetic identification of Borrelia garinii and Borrelia afzelii from patients presenting with a rare skin manifestation of prurigo pigmentosa in Taiwan. Int $\mathrm{J}$ Infect Dis 2013 Dec;17(12):e1141-7.

56. Chakravarty KK, Webley M, Summers GD. A case of chronic Lyme arthritis in England. Ann Rheum Dis. 1991 Feb;50(2):134-5.

57. Chary-Valckenaere I, Jaulhac B, Champigneulle J, Piement Y, Mainard D, and Pourel J. Ultrastructural demonstration of intracellular localization of Borrelia burgdorferi in Lyme arthritis. Br J Rheumatol 1998; 37: 468470 .

58. Chiao JW, Pavia C, Riley M, Altmann-Lasekan W, Abolhassani M, Liegner K, Mittelman A. Antigens of Lyme disease of spirochaete Borrelia burgdorferi inhibits antigen or mitogen-induced lymphocyte proliferation. FEMS Immunol Med Microbiol. 1994 Feb;8(2):151-5.

59. Chmielewski T, Tylewlska-Wierzhanowska S. Inhibition of fibroblast apoptosis by Borrelia afzelii, Coxiella burnetii and Bartonella henselae. Poll Microbiol 2011; 60(3); 269-272.

60. Chomel BB, Kasten RW, Sykes JE, Boulouis HJ, Breitschwerdt EB. Clinical impact of persistent Bartonella bacteremia in humans and animals. Ann N Y Acad Sci. 2003;990:267-278.

61. Cimmino MA, Azzolini A, Tobia F, Pesce CM. Spirochetes in the spleen of a patient with chronic Lyme disease. Am J Clin Pathol 1989; 91(1): 95-97.

62. Cimmino MA, Accardo S. Long term treatment of chronic Lyme arthritis with benzathine penicillin. Ann Rheum Dis. 1992 Aug;51(8):1007-8.

63. Cimmino MA, Moggiana GL, Parisi M, Accardo S. Treatment of Lyme arthritis. Infection. 1996 JanFeb;24(1):91-3.

64. Clarissou J, Song A, Bernede C, Guillemot D, Dinh A, Ader F, Perronne C, Salomon J. Efficacy of a long-term antibiotic treatment in patients with a chronic tick associated poly-organic syndrome (TAPOS). Med Mal Infect. 2009 Feb;39(2):108-15. 
65. Clark KL, Leydet B, Hartman S. Lyme borreliosis in human patients in Florida and Georgia, USA. Int J Med Sci. 2013 May 23;10(7):915-31.

66. Coblyn JS, Taylor P. Treatment of chronic Lyme arthritis with hydroxychloroquine. Arthritis Rheum. 1981 Dec;24(12):1567-9.

67. Collares-Pereira M, Couceiro S, Franca I, Kurtenbach K, Schäfer SM, Vitorino L, Gonçalves L, Baptista S, Vieira ML, Cunha C. First isolation of Borrelia lusitaniae from a human patient. J Clin Microbiol. 2004 Mar;42(3):1316-8.

68. Craft J, Fischer DK, Shimamoto GT, Steere AC. Antigens of Borrelia burgdorferi recognized during Lyme disease appearance of a new immunoglobulin $\mathrm{M}$ response and expansion of the immunoglobulin $\mathrm{G}$ response late in the illness. J Clin Invest. 1986; 78:934-939.

69. Czub S, Duray PH, Thomas RE, Schwan TG. Cystitis induced by infection with the Lyme disease spirochete, Borrelia burgdorferi, in mice. Am J Pathol. 1992 Nov;141(5):1173-9.

70. Dattwyler RJ, Volkman DJ, Luft BJ, Halperin JJ, Thomas J, Golightly MG. Seronegative Lyme disease. Dissociation of specific T- and B-lymphocyte response to Borrelia burgdorferi. N Engl J Med 1988; 319(22): 1441-1446.

71. Dejmková H, Hulinska D, Tegzová D, Pavelka K, Gatterová J, Vavřik P. Seronegative Lyme arthritis caused by Borrelia garinii. Clin Rheumatol 2002; 21:330-334.

72. de Koning J, Hoogkamp-Korstanje JA, van der Linde MR, Crijns HJ. Demonstration of spirochetes in cardiac biopsies of patients with Lyme disease. J Infect Dis. 1989; 160: 150-153.

73. de Leeuw BH, Maraha B, Hollemans L, Sprong H, Brandenburg AH, Westenend PJ, Kusters JG. Evaluation of Borrelia real time PCR DNA targeting OspA, FlaB and 5S-23S IGS and Borrelia 16S rRNA-qPCR. J Microbiol Methods 2014 Dec;107:41-6.

74. de Souza MS, Smith AL, Beck DS, Terwilliger GA, Fikrig E, Barthold SW. Long-term study of cell-mediated responses to Borrelia burgdorferi in the laboratory mouse. Infect Immun. 1993 May;61(5):1814-22.

75. DeLong AK, Blossom B, Maloney E, Phillips SE. Antibiotic retreatment of Lyme disease in patients with persistent symptoms: A biostatistical review of randomized, placebo-controlled, clinical trials. Contemp Clin Trials 2012 Nov;33(6):1132-42.

76. Demaerschalck I, Ben Messaoud A, De Kesel M, Hoyois B, Lobet Y, Hoet P, et al. Simultaneous presence of different Borrelia burgdorferi genospecies in biological fluids of Lyme disease patients. J Clin Microbiol 1995: 33; 602-608.

77. Dinerman H, Steere AC. Lyme disease associated with fibromyalgia. Ann Intern Med. 1992 Aug 15;117(4):281-5.

78. Diterich I, Rauter C, Kirschning CJ, Hartung T. Borrelia burgdorferi-induced tolerance as a model of persistence via immunosuppression. Infect Immun. 2003; 71(7):3979-3987.

79. Donahue JG, Piesman J, Spielman A. Reservoir competence of white-footed mice for Lyme disease spirochetes. Am J Trop Med Hyg. 1987;36: 92-96.

80. Donta ST. Tetracycline therapy for chronic Lyme disease. Clin Infect Dis. 1997; 25 (Suppl 1); S52-56.

81. Donta ST. The existence of chronic Lyme disease. Curr Treat Op Infect Dis. 2001; 3: 261-262.

82. Donta ST. Late and chronic Lyme disease. Med Clin North Am. 2002; 86: 341-349.

83. Donta ST. Macrolide therapy of chronic Lyme disease. Med Sci Monit. 2003; 9: 136-142.

84. Dorward DW, Fischer ER, Brooks DM. Invasion and cytopathic killing of human lymphocytes by spirochetes causing Lyme disease. Clin. Infect. Dis. 1997; 25 (Suppl 1): S2-8.

85. Dumler JS, Bakken JS. Human granulocytic ehrlichiosis in Wisconsin and Minnesota: a frequent infection with the potential for persistence. J Infect Dis. 1996;173:1027-1030.

86. Dunham-Ems SM, Caimano MJ, Pal U, Wolgemuth $\mathrm{CW}$, Eggers $\mathrm{CH}$, Balic A, et al. Live imaging reveals a biphasic mode of dissemination of Borrelia burgdorferi within ticks. J Clin Invest. 2009; 119: 3652-3665.

87. Duray PH, Johnson RC. The histopathology of experimentally infected hamsters with the Lyme disease spirochete, Borrelia burgdorferi. Proc Soc Exp Biol Med 1986; 181: 263-269.

88. Duray PH. The surgical pathology of human Lyme disease. An enlarging picture. Am J Surg Pathol $1987 ; 11$ (Suppl 1):47-60.

89. Duray PH, Steere AC. Clinical pathologic correlations of Lyme disease by stage. Ann NY Acad Sci 1988; 539: 65-79.

90. Duray PH, Yin SR, Ito Y, Bezrukov L, Cox C, Cho MS, et al. Invasion of human tissue ex vivo by Borrelia burgdorferi. J Infect Dis. 2005; 191(10): 1747-1754.

91. Ebel GD, Campbell EN, Goethert HK, Spielman A, Telford SR. Enzootic transmission of deer tick virus in New England and Wisconsin sites. Am J Trop Med Hyg. 2000; 63(1-2): 36-42.

92. Ekdahl KN, Henningsson AJ, Sandholm K, Forsberg P, Ernerudh J, Ekerfelt C. Immunity in borreliosis with special emphasis on the role of complement. Adv Exp Med Biol 2007; 598: 198-213. 
93. Elsner RA, Hastey CJ, Baumgarth N. CD4+ T cells promote antibody production but not sustained affinity maturation during Borrelia burgdorferi infection. Infect Immun. 2015 Jan;83(1):48-56.

94. Elsner RA, Hastey CJ, Olsen KJ, Baumgarth N. Suppression of long-lived humoral immunity following Borrelia burgdorferi infection. PLoS Pathog. 2015 Jul 2;11(7):e1004976.

95. Embers ME, Barthold SW, Borda JT, Bowers L, Doyle L, Hodzic E, et al. Persistence of Borrelia burgdorferi in rhesus macaques following antibiotic treatment of disseminated infection. PLoS ONE 2012;7(1): e29914.

96. Embers ME, Ramamoorthy R, Philipp MT. Survival strategies of Borrelia burgdorferi, the etiologic agent of Lyme disease. Microbes Infect. 2004 Mar;6(3):312-8. Review.

97. Eng TR, Harkess JR, Fishbein DB, Dawson JE, Greene CN, Redus MA, Satalowich FT. Epidemiologic, clinical, and laboratory findings of human ehrlichiosis in the United States, 1988. JAMA 1990 Nov 7;264(17):2251-8.

98. Fallon BA, Tager F, Keilp J, Weiss N, Liebowitz MR, Fein L, et al. Repeated antibiotic treatment in chronic Lyme disease. J Spiro Tick-borne Dis. 1999; 6: 94-101.

99. Feder HM, Whitaker DL. Misdiagnosis of erythema migrans. Am J Med. 1995; 99: 412-419.

100.Fein L, Tilton RC. Bone marrow as a source for Borrelia burgdorferi DNA. J Spiro Tick-borne Dis. 1997; 4: 58-60.

101.Feng J, Shi W, Zhang S, Zhang Y. Persister mechanisms in Borrelia burgdorferi: implications for improved intervention. Emerg Microbes Infect. 2015 Aug;4(8):e51.

102.Ferris i Tortajada J, López-Andreu JA, Salcedo-Vivó J, Sala-Lizarraga JV. Lyme borreliosis. Lancet 1995; 345 : 1436-1437.

103.Ferrís i Tortajada J, López-Andreu JA, Salcedo-Vivó J, Sala-Lizárraga JV. Relapsing neuroborreliosis. Eur Neurol. 1996;36:394-5.

104.Franz JK, Fritze O, Rittig M, Keysser G, Priem S, Zacher J, et al. Insights from a novel three-dimensional in vitro model of Lyme arthritis: standardized analysis of cellular and molecular interactions between Borrelia burgdorferi and synovial explants and fibroblasts. Arthritis Rheum 2001; 44: 151-162.

105.Fraser DD, Kong LI, and Miller FW. Molecular detection of persistent Borrelia burgdorferi in a man with dermatomyositis. Clin Exp Rheumatol 1992; 10: 387-390.

106. Frey M, Jaulhac B, Piemont Y, et al. Detection of Borrelia burgdorferi DNA in muscle of patients with chronic myalgia related to Lyme disease. Am J Med 1988; 104: 591-594.

107. Gaito A, Gjivoje V, Lutz S, Baxter B, II. Comparative analysis of the infectivity rate of both Borrelia burgdorferi and Anaplasma phagocytophilum in humans and dogs in a New Jersey community. Infect Drug Resist. 2014; 7: 199-201.

108. Garbe C, Stein H, Dienemann D, Orfanos CE. Borrelia burgdorferi-associated cutaneous B cell lymphoma: clinical and immunohistologic characterization of four cases. J Am Acad Dermatol. 1991 Apr;24(4):584-90.

109. Garcia-Monco JC, Benach JL. The pathogenesis of Lyme disease. Rheum Dis Clin North Am. 1989; 15: $711-726$.

110. Gasser R, Horn S, Reisinger E, Fischer L, Pokan R, Wendelin I, Klein W. First description of recurrent pericardial effusion associated with Borrelia burgdorferi infection. Int J Cardiol. 1998 May 15;64(3):309-10.

111.Gellis SE, Stadecker MJ, Steere AC. Spirochetes in atrophic skin lesions accompanied by minimal host response in a child with Lyme disease. J Am Acad Dermatol. 1991 Aug;25(2 Pt 2):395-7.

112. Georgilis K, Peacocke M, Klempner MS. Fibroblasts protect the Lyme disease spirochete, Borrelia burgdorferi, from ceftriaxone in vitro. J Infect Dis 1992; 166: 440-444.

113.Giambartolomei GH, Dennis VA, Philipp MT. Borrelia burgdorferi stimulates the production of interleukin-10 in peripheral blood mononuclear cells from uninfected humans and rhesus monkeys. Infect Immun 1998; 66: 2691-2697.

114.Girschick HJ, Huppertz HI, Rüssmann H, Krenn V, Karch H. Intracellular persistence of Borrelia burgdorferi in human synovial cells. Rheumatol Int. 1996; 16: 125-132.

115. Goodman JL, Jurkovich P, Kodner C, Johnson RC. Persistent cardiac and urinary tract infections with Borrelia burgdorferi in experimentally infected Syrian hamsters. J Clin Microbiol 1991; 29: 894-896. [hamsters]

116. Grignolo MC, Buffrini L, Monteforte P, Rovetta G. Reliability of a polymerase chain reaction (PCR) technique in the diagnosis of Lyme borreliosis. Minerva Med 2001; 92(1): 29-33.

117. Gruntar I, Malovrh T, Murgia R, Cinco M. Conversion of Borrelia garinii cystic forms to motile spirochetes in vivo. APMIS 2001; 109: 383-388.

118.Hamlen R. Tick-borne infections--a growing public health threat to school-age children. Prevention steps that school personnel can take. NASN School Nurse 2012(Mar); 27(2): 94-100.

119.Hamlen RA, Kliman DS. Pediatric Lyme disease--A school issue: Tips for school nurses. NASN School Nurse $2009 ; 24 ; 114$ 
120.Harrus S, Waner T, Aizenberg I, Foley JE, Poland AM, Bark H. Amplification of ehrlichial DNA from dogs 34 months after infection with Ehrlichia canis. J Clin Microbiol. 1998;36:73-76.

121.Harvey WT, Bransfield RC, Mercer DE, Wright AJ, Ricchi RM, Leitao MM. Morgellons disease, illuminating an undefined illness: a case series. J Med Case Rep 2009; 3:8243 .

122.Hassler D, Riedel K, Zorn J, Preac-Mursic V. Pulsed high-dose cefotaxime therapy in refractory Lyme borreliosis. Lancet 1991; 338: 193.

123. Hastey CJ, Elsner RA, Barthold SW, Baumgarth N. Delays and diversions mark the development of B cell responses to Borrelia burgdorferi infection. J Immunol. 2012 Jun 1;188(11):5612-22.

124.Häupl T, Hahn G, Rittig M, Krause A, Schoerner C, Schönherr U, Kalden JR, Burmester GR. Persistence of Borrelia burgdorferi in ligamentous tissue from a patient with chronic Lyme borreliosis. Arthritis Rheum. 1993 Nov;36(11):1621-6.

125.Henneberg JP, Neubert U. Borrelia burgdorferi group: in vitro antibiotic sensitivity. Orv Hetil 2002; 143: $1195-$ 1198.

126. Hefty PS, Brooks CS, Jett AM, White GL, Wikel SK, Kennedy RC, et al. OspE-related, OspF-related, and Elp lipoproteins are immunogenic in baboons experimentally infected with Borrelia burgdorferi and in human Lyme disease patients. J Clin Microbiol 2002;40: 4256-4265.

127.Hilton E, Tramontano A, DeVoti J, Sood SK. Temporal study of immunoglobulin M seroreactivity to Borrelia burgdorferi in patients treated for Lyme borreliosis. J Clin Microbiol 1997; 35(3): 774-776.

128.Hodzic E, Feng S, Barthold SW. Stability of Borrelia burgdorferi outer surface protein C under immune selection pressure. J Infect Dis. 2000; 181: 750-753.

129.Hodzic E, Feng S, Holden K, Freet KJ, Barthold SW. Persistence of Borrelia burgdorferi following antibiotic treatment in mice. Antimicrob Agents Chemother 2008; 52: 1728-1736.

130.Holden K, Hodzic E, Feng S, Freet KJ, Lefebvre RB, Barthold SW. Coinfection with Anaplasma phagocytophilum alters Borrelia burgdorferi population distribution in $\mathrm{C} 3 \mathrm{H} / \mathrm{HeN}$ mice. Infect Immun. 2005 Jun;73(6):3440-4.

131. Holl-Weiden A, Suerbaum S, Girschick HJ. Seronegative Lyme arthritis. Rheumatol Int 2007; 11: $1091-1093$.

132.Honegr K, Hulinska D, Dostal V, Gebouský P, Hanková E, Horácek J, et al. Persistence of Borrelia burgdorferi sensu lato in patients with Lyme borreliosis. Epidemiol Mikrobiol Immunol. 2001; 50: 10-16.

133. Huang CY, Chen YW, Kao TH, Kao HK, Lee YC, Cheng JC, Wang JH. Hyperbaric oxygen therapy as an effective adjunctive treatment for chronic Lyme disease. J Chin Med Assoc. 2014 May;77(5):269-71.

134.Hudson BJ, Stewart M, Lennox VA, Fukunaga M, Yabuki M, Macorison H, et al. Culture-positive Lyme borreliosis. Med J Aust. 1998; 168(10): 500-502.

135. Hulínská D, Krausova M, Janovská D, Rohácová H, Hancil J, Mailer H. Electron microscopy and the polymerase chain reaction of spirochetes from the blood of patients with Lyme disease. Cent Eur J Public Health 1993; 1(2): 81-85.

136. Hulínská D, Votypka J, Valesova M. Persistence of Borrelia garinii and Borrelia afzelii in patients with Lyme arthritis. Int J Med Microbiol Virol Parasitol Infect Dis 1999; 289(3): 301-318.

137. Hunfeld KP, Ruzic-Sabljic E, Norris DE, Kraiczy P, Strle F. In vitro susceptibility testing of Borrelia burgdorferi sensu lato isolates cultured from patients with erythema migrans before and after antimicrobial chemotherapy. Antimicro Agents Chemother 2005; 49: 1294-1301.

138. Hyde JA. Borrelia burgdorferi keeps moving and carries on: A review of Borrelial dissemination and invasion. Front. Immunol. 2017;8:114.

139.Johnson RC, Marek N, Kodner C. Infection of Syrian hamsters with Lyme disease spirochetes. J Clin Microbiol. 1984; 20: 1099-1101.

140.Johnson L, Stricker RB. Treatment of Lyme disease: a medicolegal assessment. Expert Rev Anti-Infect Ther 2004. 2: 533-557.

141. Kaiser R. Clinical courses of acute and chronic neuroborreliosis following treatment with ceftriaxone. Nervenarzt. 2004; 75(6): 553-557.

142. Kalish RA, Leong JM, Steere AC. Association of treatment-resistant chronic Lyme arthritis with HLA-DR4 and antibody reactivity to OspA and OspB of Borrelia burgdorferi. Infect Immun 1993; 61: 2774-2779.

143. Kalish RA, McHugh G, Granquist J, Shea B, Ruthazer R, Steere AC. Persistence of immunoglobulain M or immunoglobulin $\mathrm{G}$ antibody responses to Borrelia burgdorferi 10-20 years after active Lyme disease. Clin Infect Dis 2001; 33: 780-785.

144. Karch H, Huppertz HI. Repeated detection of Borrelia burgdorferi DNA in synovial fluid of a child with Lyme arthritis. Rheumatol Int. 1993;12(6):227-9. 
145.Kaya G, Berset M, Prins C, Chavaz P, Saurat JH. Chronic borreliosispresenting with morphea- and lichen sclerosus et atrophicus-like cutaneous lesions. a case report. Dermatology. 2001;202(4):373-5

146.Keat AC, and Hughes R. Infectious agents in reactive arthritis. Curr Opin Rheumatol 1993; 5: 414-419.

147.Kersten A, Poitschek C, Rauch S, and Aberer E. Effects of penicillin, ceftriaxone, and doxycycline on morphology of Borrelia burgdorferi. Antimicrob Agents Chemother 1995; 39: 1127-1133.

148. Keszler K, Tilton RC. Persistent PCR positivity in a patient being treated for Lyme disease. J Spiro Tick-borne Dis 1995; 2: 57-58.

149.Kirsch M, Ruben FL, Steere AC, Duray PH, Norden CW, Winkelstein A. Fatal adult respiratory distress syndrome in a patient with Lyme disease. JAMA 1988; 259(18) 2737-2739.

150.Klempner MS, Noring R, and Rogers RA. Invasion of human skin fibroblasts by the Lyme disease spirochetes, Borrelia burgdorferi. J Infect Dis 1993; 167: 1074-81.

151.Klemann W, Huismans BD, and Heyl S. Prolonged antibiotic therapy in PCR persistent Lyme disease. Grin Verlag 2011. ISBN 978-3-640-82803-6

152.Kraiczy P, Hellwage J, Skerka C, Becker H, Kirschfink M, Simon MM, et al. Complement resistance of Borrelia burgdorferi correlates with the expression of BbCRASP-1, a novel linear plasmid-encoded surface protein that interacts with human factor H and FHL-1 and is unrelated to Erp proteins. J Biol Chem 2004; 279: 2421-2429.

153.Krause PJ, Spielman A, Telford SR, Sikand VK, McKay K, Christianson D, et al. Persistent parasitemia after acute babesiosis. N Engl J Med. 1998;339:160-165.

154.Krause PJ, Telford SR 3rd, Spielman A, Sikand V, Ryan R, Christianson D, Burke G, Brassard P, Pollack R, Peck J, Persing DH. Concurrent Lyme disease and babesiosis. Evidence for increased severity and duration of illness. JAMA. 1996 Jun 5;275(21):1657-60.

155.Kugeler KJ, Griffith KS, Gould LH, Kochanek K, Delorey MJ, Biggerstaff BJ, et al. A review of death certificates listing Lyme disease as a cause of death in the United States. Clin Infect Dis. 2011; 52: 364-367.

156.Kullberg BJ, Berende A, van der Meer JW. The challenge of Lyme disease: tired of the Lyme wars. Neth J Med 2011; 69: 98-100.

157.Lawrenz MB, Hardham JM, Owens RT, Nowakowski J, Steere AC, Wormser GP, Norris SJ. Human antibody responses to vlsE antigenic variation protein of Borrelia burgdorferi. J Clin Microbiol 1999; 37: 3997-4004.

158.Lee SH, Vigliotti JS, Vigliotti VS, James W, Moorcroft TA, Lantsman K. DNA sequencing diagnosis of off-season spirochetemia with low bacterial density in Borrelia burgdorferi and Borrelia miyamotoi infections. Int. J. Mol. Sci. 2014; 15: 11364-11386.

159. Leff RD, Akre SP. Late stage Lyme borreliosis in children. South Med J. 1989 Aug;82(8):954-6.

160.Leverkus M, Finner AM, Pokrywka A, Franke I, Gollnick H. Metastatic squamous cell carcinoma of the ankle in long-standing untreated acrodermatitis chronica atrophicans. Dermatology. 2008;217(3):215-8.

161.Levy E, Morruzzi C, Barbarini A, Sordet C, Cribier B, Jaulhac B, Lipsker D. Clinical images: toe dactylitis revealing late Lyme borreliosis. Arthritis Rheum. 2012 Apr;64(4):1293.

162.Li X, McHugh GA, Damle N, Sikand VK, Glickstein L, Steere AC. Burden and viability of Borrelia burgdorferi in skin and joints of patients with erythema migrans or Lyme arthritis. Arthritis Rheum 2011;63: 2238-2247.

163.Liang FT, Steere AC, Marques AR, Johnson BJB, Miller JN, Philipp MT. Sensitive and specific serodiagnosis of Lyme disease by enzyme-linked immunosorbent assay with a peptide based on an immundominant conserved region of Borrelia burgdorferi VlsE. J Clin Microbiol 1999; 37: 3990-3996.

164.Liang FT, Jacobs MB, Bowers LC, Philipp MT. An immune evasion mechanism for spirochetal persistence in Lyme borreliosis. J Exp Med 2002; 195: 415-422.

165.Liegner KB. Minocycline in Lyme disease. J Am Acad Dermatol. 1992 Feb;26(2 Pt 1):263-4.

166.Liegner KB. Lyme disease: the sensible pursuit of answers. J Clin Microbiol 1993; 31: 1961-1963.

167.Liegner KB, Shapiro JR, Ramsay D, Halperin AJ, Hogrefe W, Kong L. Recurrent erythema migrans despite extended antibiotic treatment with minocycline in a patient with persisting Borrelia burgdorferi infection. $\mathrm{J}$ Am Acad Dermatol 1993; 28: 312-314.

168.Ljostad J, Mygland Å. Chronic Lyme: diagnostic and therapeutic challenges. Acta Neurol Scand 2013;196: 38-47.

169.Logigian EL, Johnson KA, Kijewski MF, Kaplan RF, Becker JA, Jones KJ, Garada BM, Holman BL, Steere AC. Reversible cerebral hyoperfusion in Lyme encephalopathy. Neurology 1997; 49: 1661-1670.

170.López-Andreu JA, Ferrís J, Canosa CA, Sala-Lizárraga JV. Treatment of late Lyme disease: a challenge to accept. J Clin Microbiol 1994; 32:1415-1416.

171.Ma Y, Sturrock A, Weis JJ. Intracellular localization of Borrelia burgdorferi within human endothelial cells. Infect Immun 1991; 59: 671-678.

172. MacDonald AB. Biofilms of Borrelia burgdorferi on chironic cutaneous borrelia. Am J Clin Pathol 2008; 129: $988-989$. 
173. MacDonald, AB. Borrelia burgdorferi tissue morphologies and imaging methodologies. Eur J Clin Microbiol Infect Dis 2013; 32(8): 1077-82.

174. MacDonald AB. A life cycle for Borrelia spirochetes? Med Hypotheses. 2006;67(4):810-8.

175. Maggi RG, Ericson M, Mascarelli PE, Bradley JM, Breitschwerdt EB. Bartonella henselae bacteremia in a mother and son potentially associated with tick exposure Parasites \& Vectors April 2013, 6:101.

176. Mahmoud AAF. The challenge of intracellular pathogens (editorial). N Engl J Med 1992; 326: 761-762.

177. Malane MS, Grant Kels JM, Feder HM Jr, Luger SW. Diagnosis of Lyme disease based on dermatologic manifestations. Ann Intern Med 1991; 114:490-498.

178. Malawista SE, Barthold SW, and Persing DH. Fate of Borrelia burgdorferi DNA in tissues of infected mice after antibiotic treatment. J Infect Dis 1994; 170: 1312-1316.

179. Malawista SE. Resolution of Lyme arthritis, acute or prolonged: a new look. Inflammation. 2000 Dec;24(6):493-504.

180.Manak MK, González-Villaseñor LI, Crush-Stanton S, and Tilton RC. Use of PCR assays to monitor the clearance of Borrelia burgdorferi DNA from blood following antibiotic therapy. J Spir Tick-Borne Dis 1997; 4: 11-20.

181.Maraspin V, Ruzic-Sabljic E, Strle F, Cimperman J, Jereb M, Preac-Mursic V. Persistence of Borrelia burgdorferi after treatment with antibiotics. Alpe Adria Microbiol J. 3: 211-216.

182. Maraspin V, Cimperman J, Lotrič-Furlan S, Ružić-Sabljić E, Jurca T, Picken RN, Strle F. Solitary borrelial lymphocytoma in adult patients. Wien Klin Wochenschr 2002; 114: 515-523.

183. Marlovits S, Khanah G, Striessniq G, Vécsei V, and Stanek G. Emergence of Lyme arthritis after autologous chondrocyte transplantation. Arthritis Rheum. 2004; 50: 259-264.

184. Masters EJ, Lynxwiler P, and Rawlings J. Spirochetemia after continuous high-dose oral amoxicillin therapy. Infect Dis Clin Practice 1995; 3: 207-208.

185. Mayer W, Kleber FX, Wilske B, Preac-Mursic V, Maciejewski W, Sigl H, Holzer E, Doering W. Persistent atrioventricular block in Lyme borreliosis. KlinWochenschr. 1990 Apr 17;68(8):431-5.

186. McAlister HF, Klementowicz PT, Andrews C, Fisher JD, Feld M, Furman S. Lyme carditis: an important cause of reversible heart block. Ann Intern Med. 1989 Mar 1;110(5):339-45.

187. McLaughlin TP, Zemel L, Fisher RL, Gossling HR. Chronic arthritis of the knee in Lyme disease. Review of the literature and report of two cases treated by synovectomy. J Bone Joint Surg Am. 1986 Sep;68(7):1057-61.

188. Meier P, Blatz R, Gau M, Spencker FB, Wiedermann P. [Pars plana vitrectomy in Borrelia burgdorferi endophthalmitis][German]. Klin Monatsbl Augenheilkd 1998; 213(6): 351-354.

189. Middelveen MJ, Bandoski C, Burke J, Sapi E, Filush KR, Wang Y, et al. Exploring the association between Morgellons disease and Lyme disease: identification of Borrelia burgdorferi in Morgellons disease patients. BMC Dermatol. 2015;15:1.

190. Middelveen MJ, Stricker RB. Morgellons disease: a filamentous borrelial dermatitis. Int J Gen Med 2016:9 349-354

191. Middelveen, MJ, McClain SA, Bandoski C, Israel JR, Burke J, MacDonald AB, Sapi E, Wang Y, Franco A, Mayne PJ, Stricker RB. Granulomatous hepatitis associated with chronic Borrelia burgdorferi infection: a case report. Research 2014; 1: 875. http://dx.doi.org/10.130070/rs.en.1.875.

192. Miller JC, Narayan K, B Stevenson B, Pachner AR. Expression of Borrelia burgdorferi erp genes during infection of non-human primates. Microb Pathol. 2005; 39: 27-33.

193. Montgomery RR, Nathanson MH, Malawista SE. The fate of Borrelia burgdorferi within endothelial cells. Infect Immun 1991; 59: 671-678.

194.Montgomery RR, Nathanson MH, Malawista SE. The fate of Borrelia burgdorferi, the agent for Lyme disease, in mouse macrophages. Destruction, survival, recovery. J Immunol 1993; 150: 909-915.

195. Moody KD, Barthold SW, Terwilliger GA. Lyme borreliosis in laboratory animals: effect of host species and into passage of Borrelia burgdorferi. Am J Trop Med Hyg 1990; 43: 87-92.

196. Moody KD, Barthold SW, Terwilliger GA, Beck DS, Hansen GM, Jacoby RO. Experimental chronic Lyme borreliosis in Lewis rats. Am J Trop Med Hyg 1990;42: 65-74.

197.Moody KD, Adams RL, and Barthold SW. Effectiveness of antimicrobial treatment against Borrelia burgdorferi infection in mice. Anticrob Agents Chemother 1994; 38: 1567-1572.

198. Moriarty TJ, Norman MU, Colarusso P, Bankhead T, Kubes P, and Chaconas G. Real-time high resolution 3D imaging of the Lyme disease spirochete adhering to and escaping from the vasculature of a living host. PLoS Pathog. 2008; 4(6):e1000090.

199. Moro MH, Zegarra-Moro OL, Bjornsson J, Hofmeister EK, Bruinsma E, Germer JJ, Persing DH. Increased arthritis severity in mice coinfected with Borrelia burgdorferi and Babesia microti. J Infect Dis. 2002; 186: 428-431.

200.Müllegger RR, Glatz M. Skin manifestations of Lyme borreliosis: diagnosis and management. Am J Clin Dermatol. 2008;9(6):355-68. 
201.Müller KE. Damage of collagen and elastic fibres by Borrelia burgdorferi-known and new clinical and histopathological aspects. Open Neurol J. 2012; 6: 179-186.

202. Murillo G, Ramírez B, Romo LA, Muñoz-Sanz A, Hileeto D, Calonge M. Oculopalpebral borreliosis as an unusual manifestation of Lyme disease. Cornea. 2013 Jan;32(1):87-90.

203.Mursic VP, Wanner G, Reinhardt S, Wilske B, Busch U, Marget W. Formation and cultivation of Borrelia burgdorferi spheroplast L-form variants. Infection 1996; 24(4): 335.

204. Nanagara R, Duray PH, and Schumacher HR, Jr. Ultrastructural demonstration of spirochetal antigens in synovial fluid and synovial membrane in chronic Lyme disease: possible factors contributing to persistence of organisms. Hum Pathol 1996; 27(10): 1025-1034.

205. Nocton JJ, Dressler F, Rutledge BJ, Rys PN, Persing DH, Steere AC. Detection of Borrelia burgdorferi DNA by polymerase chain reaction in synovial fluid from patients with Lyme arthritis. N Eng J Med 1994; 330: 229-234.

206. Norgard MV, Riley BS, Richardson JA, Radolf JD. Dermal inflammation elicited by synthetic analogs of Treponema pallidum and Borrelia burgdorferi lipoproteins. Infect Immun 1995;63:1507-1515.

207. Ogden NH, Arsenault J, Hatchette TF, Mechai S, Lindsay LR. Antibody responses to Borrelia burgdorferi detected by Western blot vary geographically in Canada. PLoS One. 2017 Feb 9;12(2):e0171731.

208. Oksi J, Voipio-Pulkki LM, Uksila J, Pulkki K, Laippala P, Viljanen MK. Borrelia burgdorferi infection in patients with suspected acute myocardial infarction. Lancet. 1997 Nov 15;350:1447-8.

209. Oksi J, Mertsola J, Reunanen M, Marjamaki M, Viljanen MK. Subacute multiple-site osteomyelitis caused by Borrelia burgdorferi. Clin Infect Dis 1994; 19(5): 891-896.

210.Oksi J, Uksila J, Marjamäki M, Nikoskelainen J, Viljanen MK. Antibodies against whole sonicated Borrelia burgdorferi spirochetes, 41-kilodalton flagellin, and P39 protein in patients with PCR- or culture-proven late Lyme borreliosis. J Clin Microbiol 1995; 33: 2260-2264.

211.Oksi J, Nikoskelainen J, Viljanen MK. Comparison of oral cefixime and intravenous ceftriaxone followed by oral amoxicillin in disseminated Lyme borreliosis. Eur J Clin Microbiol Int Dis 1998; 17: 715-719.

212. Oksi J, Marjamäki M, Nikoskelainen J, Viljanen MK. Borrelia burgdorferi detected by culture and PCR in clinical relapse of disseminated Lyme borreliosis. Ann Med 1999; 31(3): 225-232.

213.Pachner AR, Delaney E, Ricalton NS. Murine Lyme borreliosis: route of inoculation determines immune response and infectivity. Reg Immunol. 1992 Nov-Dec;4(6):345-51.

214.Pachner AR, Ricalton N, Delaney E. Comparison of polymerase chain reaction with culture and serology for diagnosis of murine experimental Lyme borreliosis. J Clin Microbiol. 1993 Feb;31(2):208-14.

215.Pachner AR, Delaney E, O'Neill T. Neuroborreliosis in the nonhuman primate: Borrelia burgdorferi persists in the central nervous system. Ann Neurol 1995; 38: 667-9.

216.Pachner AR, Basta J, Delaney E, Hulinska D. Localization of Borrelia burgdorferi in murine Lyme borreliosis by electron microscopy. Am J Trop Med Hyg 1995; 52: 128-133.

217.Pachner AR, Cadavid D, Shu G, Dail D, Pachner S, Hodzic E, Barthold SW. Central and peripheral nervous system infection, immunity, and inflammation in the NHP model of Lyme borreliosis. Ann Neurol 2001; 50: 330338. [in monkeys]

218.Pachner AR, Dail D, Narayan K, Dutta K, Cadavid D. Increased expression of B-lymphocyte chemoattractant, but not pro-inflammatory cytokines, in muscle tissue in rhesus chronic Lyme borreliosis. Cytokine 2002; 19: $297-307$.

219.Pahl A, Kühbrandt U, Brune K, Röllinghoff M, Gessner A. Quantitative detection of Borrelia burgdorferi by realtime PCR. J Clin Microbiol 1999; 37: 1958-1963.

220.Pal GS, Baker JT, Wright DJM. Penicillin resistant Borrelia encephalitis responding to cefotaxime. Lancet 1988; 338: $50-51$.

221.Pál E, Barta Z, Nagy F, Wágner M, Vécsei L. Neuroborreliosis in county Baranya, Hungary. Funct Neurol. 1998 Jan-Mar;13(1):37-46.

222.Pedersen LM, Friis-Møller A. Late treatment of chronic Lyme arthritis. Lancet. 1991 Jan 26;337(8735):241.

223.Petrovic M, Vogelaers D, Van Renterghem L, Carton D, De Reuck J, Afschrift M. Lyme borreliosis - review of the late stages and treatment of four cases. Acta Clin Belg. 1998; 53: 178-183.

224.Pfister HW, Preac Mursic V, Wilske B, Schielke E, Sorgel F, Einhaupl KMJ. Randomized comparison of ceftriaxone and cefotaxime in Lyme neuroborreliosis. Infect Dis 1991; 163(2): 311-318.

225.Phillips SE, Mattman LH, Hulinska D, Moayad H. A proposal for the reliable culture of Borrelia burgdorferi from patients with chronic Lyme disease, even from those aggressively treated. Infection 1998; 26: 364-67.

226.Phillips SE, Harris NS, Horowitz R, Johnson L, Stricker RB. Lyme disease: scratching the surface. Lancet 2005; 366: 1771. 
227.Phillips SE, Burrascano JJ, Harris NS, Johnson L, Smith PV, Stricker RB. Chronic infection in 'post-Lyme borreliosis syndrome. Int J Epidemiol 2005; 34: 1439-1440.

228.Picha D, Moravcová L, Holecková D, Zd'árský E, Valesová M, Maresová V, et al. Examination of specific DNA by PCR in clinical relapse of disseminated Lyme borreliosis. Int J Dermatol. 2008; 47: 1004-1010.

229.Picken RN, Strle F, Picken MM, Ruzic-Sabljic E, Maraspin V, Lotric-Furlan S, et al. Identification of three species of Borrelia burgdorferi sensu lato (B. garinii, B. afzelii) among isolates from acrodermatis chronica atrophicans lesions. J Invest Dermatol 1998; 110;211-214.

230.Preac-Mursic V, Weber K, Pfister HW, Pfister HW, Wilske B, Gross B, et al. Survival of Borrelia burgdorferi in antibiotically treated patients with Lyme borreliosis. Infection 1989; 17: 355-359.

231.Preac-Mursic V, Patsouris E, Wilske B, Reinhardt S, Gross B, Mehraein P. Persistence of Borrelia burgdorferi and histopathological alterations in experimentally infected animals: a comparison with histopathological findings in human Lyme disease. Infection 1990; 18: 332-341.

232.Preac-Mursic V, Pfister HW, Spiegel H, Burk R, Wilske B, Reinhardt S, et al. First isolation of Borrelia burgdorferi from an iris biopsy. J Clin Neuroophthalmol 1993; 13(3): 155-161.

233.Preac Mursic V, Wanner G, Reinhardt S, Wilske B, Busch U, Marget W. Formation and cultivation of Borrelia burgdorferi spheroplast-L-form variants. Infection 1996; 24: 218-226.

234.Preac Mursic V, Marget W, Busch U, Rigler DP, Hagl S. Kill kinetics of Borrelia burgdorferi and bacterial findings in relation to the treatment of Lyme borreliosis. Infection 1996; 24(1): 9-16. [Bb was isolated by culture in five patients, four of whom had previously tested antibody-negative.]

235.Priem S, Burmester GR, Kamradt T, Wolbart K, Rittig MG, Krause A. Detection of Borrelia burgdorferi by polymerase chain reaction in synovial membrane, but not in synovial fluid from patients with persisting Lyme arthritis after antibiotic therapy. Ann Rheum Dis 1998;57: 118-121.

236. Reid MC, Schoen RT, Evans J, Rosenberg JC, and Horowitz RI. The consequences of overdiagnosis and overtreatment of Lyme disease: an observational study. Ann Intern Med. 1998;128(5): 354-362.

237. Reimers CD, de Koning J, Neubert U, Preac Mursic V, Koster JG, Muller Felberl W, Pongratz DE, Duray PH. Borrelia burgdorferi myositis: report of eight patients. J Neurol 1993; 240(5):278-283.

238. Reis C, Cote M, Le Rhun D, Lecuelle B, Levin ML, Vayssier-Taussat M, Bonnet SI. Vector competence of the tick Ixodes ricinus for transmission of Bartonella birtlesii. PLoS Negl Trop Dis. 2011;5(5):e1186.

239. Rittig MG, Häupl T, Krause A, Kressel M, Groscurth P, Burmester GR. Borrelia burgdorferi-induced ultrastructural alterations in human phagocytes: a clue to pathogenicity? J Pathol 1994; 173: 269-282.

240.Roberts ED, Bohm RP Jr, Cogswell FB, Lanners HN, Lowrie RC Jr, Povinelli L, et al. Chronic Lyme disease in the rhesus monkey. Lab Invest. 1995;72: 146-160.

241.Roberts ED, Bohm RP Jr, Lowrie RC Jr, Habicht G, Katona L, Piesman J, et al. Pathogenesis of Lyme neurobororeliosis in the rhesus monkey: the early disseminated and chronic phases of disease in the peripheral nervous system. J Infect Dis 1998; 178: 722-732.

242. Rocha R, Lisboa L, Neves J, García López M, Santos E, Ribeiro A. Neuroborreliosis presenting as acute disseminated encephalomyelitis. Pediatr Emerg Care. 2012 Dec;28(12):1374-6.

243. Rohácová H, Hancil J, Hulinská D, Mailer H, Havlik J. Ceftriaxone in the treatment of Lyme neuroborreliosis. Infection. 1996 (Jan-Feb); 24(1): 88-90.

244.Roelcke U, Barnett W, Wilder-Smith E, Sigmund D, and Hacke W. Untreated neuroborreliosis: Bannwarth syndrome evolving into acute schizophrenia-like psychosis. J Neurol 1992; 239: 129-131.

245.Rosa Neto NS, Gauditano G, Yoshinari NH. Chronic lymphomonocytic meningoencephalitis, oligoarthritis and erythema nodosum: report of Baggio-Yoshinari syndrome of long and relapsing evolution. Rev Bras Reumatol. 2014 Mar-Apr;54(2):148-51.

246.Ruzic-Sablijic E, Strle F, and Cimperman J. The Ixodes ricinus tick as a vector of Borrelia burgdorferi in Slovenia. Eur J Epidemiol 1993; 9: 396-400.

247. Sala-Lizarraga JA, Salcede-Vivo J, Ferris J, Lopez-Andreu JA. Lyme borreliosis Lancet 1990; 345: $1436-1437$.

248. Salit IE, Artsob H, Cheung SC. Imported case of Bannwarth's syndrome (chronic lymphocytic meningoradiculitis or Lyme meningitis). Can Dis Wkly Rep. 1988 Feb 27;14(8):31-4.

249. Sapi E, and MacDonald A. Biofilms of Borrelia burgdorferi in chronic cutaneous borreliosis. Am. J. Clin. Pathol. 2008; 129: 988-989. [biofilms consist of a colony of spirochetes and cysts coated by a gelatinous, protective membrane]

250.Sapi E, Kaur N, Anyanwu S, Luecke DF, Datar A, Patel S, Rossi M, Stricker RB. Evaluation of in vitro antibiotic susceptibility of different morphologic form of Borrelia burgdorferi. Drug Resist. 2011; 4: 97-113.

251.Sapi E, Bastian SL, Mpoy CM, Scott S, Rattelle A, Pabbati N, Poruri A, Buruga D, Theophilus PAS, Pham TV, Datar A, Dhaliwai NK, MacDonald A, Rossi MJ, Sinha SK, and Luecke DF. 2012. Characterization of biofilm formation by Borrelia burgdorferi in vitro. PLOS One 7(10): e48277. doi: 10.1371/journal.pone.0048277 [biofilms consist of a colony of spirochetes and cysts coated by a gelatinous, protective membrane] 
252. Sapi E, Pabbati N, Datar A, Davies EM, Rattelle A and Kuo BA. Improved culture conditions for the growth and detection of Borrelia from human serum. Int J Med Sci 2013; 10: 362-376.

253. Sauer A, Hansmann Y, Jaulhac B, Bourcier T, Speeg-Schatz C. Five cases of paralytic strabismus as a rare feature of Lyme disease. Clin Infect Dis. 2009 Mar 15;48(6):756-9.

254. Schoen RT, Aversa JM, Rahn DW, Steere AC. Treatment of refractory chronic Lyme arthritis with arthroscopic synvectomy. Arthritis Rheum 1991; 34(8): 1056-1060.

255. Schned ES. Lyme disease as an etiology of "unexplained" recurrent monoarthritis. Minn Med. 1984 Jun;67(6):325-8.

256. Schneider BS, Schriefer ME, Dietrich G, Dolan MC, Morshed MG, Zeidner NS. Borrelia bissettii isolates induce pathology in a murine model of disease. Vector Borne Zoonotic Dis. 2008 Oct;8(5):623-33.

257. Schmidli J, Hunziker T, Moesli P, Schaad UB. Cultivation of Borrelia burgdorferi from joint fluid three months after treatment of facial palsy due to Lyme borreliosis. J Inf Dis 1988; 158(4): 905-906. [Bb was cultured from joint fluid after treatment.]

258.Schmitz JL, Schell RF, Lovrich SD, Callister SM and Coe JE; Characterization of the protective antibody response to Borrelia burgdorferi in experimentally infected LDH hamsters. Infect Immun 1991; 59: 1916-1921.

259. Schwan TG, Burgdorfer W, Schrumpf ME, Karstens RH. The urinary bladder: a consistent source of Borrelia burgdorferi in experimentally infected white-footed mice (Peromyscus leucoupus). J Clin Microbiol. 1988;26: 893-895.

260.Schwan TG, MacDonald AB. Interstitial cystitis and Borrelia burgdorferi. Ann Intern Med. 1989 Sep $15 ; 111(6): 537$.

261. Schwan TG, Piesman J, Golde WT, Dolan MC, Ros PA. Induction of an outer surface protein on Borrelia burgdorferi during tick feeding. Proc Natl. Acad. Sci. USA. 1995; 92: 2909-2913.

262. Seiler KP, and Weis JJ. Immunity to Lyme disease: protection, pathology and persistence. Curr Opin Immunol 1996; 8: 503-509.

263. Shadick NA, Phillips CB, Logigian EL, Steere AC, Kaplan RF, Berardi VP, et al. The long-term clinical outcomes of Lyme disease. A population-based retrospective cohort study. Ann Intern Med 1994; 121: 560-567.

264. Sharma B, Brown AV, Matluck NE, Hu LT, Lewis K. Borrelia burgdorferi, the causative agent of Lyme disease, forms drug-tolerant persister cells. Antimicrob Agents Chemother. 2015 Aug;59(8):4616-24.

265. Shui Y, Tao W, Huang D, Li Y, Fan B. Spinal cord stimulation for chronic pain originating from Lyme disease. Pain Physician. 2012 Nov-Dec;15(6):511-4.

266. Singh SK and HJ Girschick. Molecular survival strategies of the Lyme disease spirochete Borrelia burgdorferi. Lancet Infect Dis 2004; 4: 575-583. [B. burgdorferi survives in ligaments, tendons, fibroblasts, synovial cells, endothelial cells, deep invaginations of cell membranes, myocyctes, joints, eyes, and bones.]

267. Skogman BH, Croner S, Nordwall M, Eknefelt M, Ernerudh J, and Forsberg P. Lyme neuroborreliosis in children: a prospective study of clinical features, prognosis, and outcome. Pediatic Infect. Dis. J. 2008; 27(12): 1089-1094.

268. Snydman DR, Schenkein DP, Berardi VP, Lastavica CC, Pariser KM. Borrelia burgdorferi in joint fluid in chronic Lyme arthritis. Ann Intern Med. 1986;104(6):798-800.

269. Sonnesyn SW, Manivel JC, Johnson RC, Goodman JL. A guinea pig model for Lyme disease. Infect Immun. 1993;61: 4777-4784. [guinea pig]

270. Stanek G, Klein J, Bittner R, and Glogar D. Isolation of Borrelia burgdorferi from the myocardium of a patient with long standing cardiomyopathy. N Engl J Med 1990; 322: 249-252.

271. Steere AC, Duray PH, Butcher EC. Spirochetal antigens and lymphoid cell surface markers in Lyme synovitis. Comparison with rheumatoid synovium and tonsillar lymphoid tissue. Arthritis Rheum 1988; 31: 487-495.

272. Steere AC, Bernardi VP, Weeks KE, Logigan EL, Ackermann R. Evaluation of the intrathecal antibody response to Borrelia burgdorferi as a diagnostic test for Lyme neuroborreliosis. J. Infect. Dis. 1990; 161(6): 1203-1209.

273. Steere AC, Taylor E, McHugh GL, Logigian EL. The overdiagnosis of Lyme disease. JAMA. 1993; 269(14): 1812-1816.

274. Steere AC, Levin RE, Molloy PJ, Kalis RA, Abraham JH, Liu NY, Schmid CH. Treatment of Lyme arthritis. Arthritis Rheum 1994; 37: 878-888.

275. Stone BL, Brissette CA. Host immune evasion by Lyme and Relapsing Fever Borreliae: Findings to lead future studies for Borrelia miyamotoi. Front Immunol. 2017 Jan 19;8:12

276. Straubinger RK, Straubinger AF, Jacobson RH, Chang Y, Summers BA, Erb HN, Appel MJG. Two lessons from the canine model of Lyme disease: migration of Borrelia burgdorgferi in tissues and persistence after antibiotic treatment. J Spiro Tick-borne Dis 1997; 4: 24-31.

277. Straubinger RK, Summers BA, Chang YF, Appel MJG. Persistence of Borrelia burgdorferi in experimentally infected dogs after antibiotic treatment. J Clin Microbiol 1997;35: 111-116.

278. Straubinger RK. PCR-based quantification of Borrelia burgdorferi organisms in canine tissues over a 500-day postinfection period. J Clin Microbiol 2000; 38: 2191-2199. 
279. Straubinger RK, Straubinger AF, Summers BA, Jacobson RH. Status of Borrelia burgdorferi infection after antibiotic treatment and the effects of corticosteroids: an experimental study. J Infect Dis 2000;181: 1069-1081.

280. Stricker RB, Winger EE. Decreased CD57 lymphocyte subset in patients with chronic Lyme disease. Immunology Letters. 2001. 76: 43-48.

281. Stricker RB, Burrascano JJ, Winger EE. Long-term decrease in the CD57 lymphocyte subset in a patient with chronic Lyme disease. Ann Agric Environ Med 2002; 9: 111-113.

282. Stricker RB, Lautin A, Burrascano JJ. Lyme disease: point/counterpoint. Expert Rev Anti-Infect Ther 2005: 3: 155-165.

283. Stricker RB. Counterpoint: long-term antibiotic therapy improves persistent symptoms associated with Lyme disease. Clin Infect Dis 2007; 45: 149-157.

284. Stricker RB and Johnson L. Persistent Borrelia burgdorferi infection after treatment with antibiotics and anti-tumor necrosis factor- $\alpha$. J Infect Dis 2008; 197: 1352-1353.

285. Stricker RB, Johnson L. Lyme disease diagnosis and treatment: lessons from the AIDS epidemic. Minerva Med. 2010;101(6):419-425.

286. Stricker RB, Johnson L. Lyme disease: the next decade. Infect. Drug Resist. 2011; 4: 1-9.

287. Stricker RB, Johnson L. Persistent infection in chronic Lyme disease: does form matter? Res J Infect Dis $2013 ; 1: 2$. http://dx.doi.org/10.7243/2052-5958-1-2.

288. Stricker RB, Johnson L. Borrelia burgdorferi aggrecanase activity: more evidence for persistent infection in Lyme disease. Front Cell Infect Microbiol. 2013 Aug 14;3:40.

289. Strle F, Preac-Mursic V, Cimperman J, Ruzic E, Maraspin V, and Jereb M. Azithromycin versus doxycycline for treatment of eythema migrans: clinical and microbiological findings. Infection 1993; 21(2): 83-88.

290.Strle F, Cheng Y, Cimperman J, Maraspin V, Lotric-Furlan S, Nelson JA, Picken MM, Ruzic-Sabljic E, and Picken R. Persistence of Borrelia burgdorferi sensu lato in resolved erythema migrans lesions. Clin Infect Dis 1995; 23: 380-389.

291. Strle F, Maraspin V, Lotric-Furlan, Ruzic-Sabljic E, Cimperman J. Azithromycin and doxycycline for treatment of Borrelia culture-positive erythema migrans. Infection 1996; 24: 64-68. [Skin-positive despite repeated antibiotic treatments.]

292.Summers BA, Straubinger AF, Jacobson RH, Chang YF, Appel MJG, Straubinger RK. Histopathological studies of experimental Lyme disease in the dog. J Comparative Pathol 2005; 133: 1-13.

293. Sung SY, McDowell JV, Carlyon JA, and Marconi RT. Mutation and recombination in the upstream homology box-flanked OspE-related genes of the Lyme disease spirochetes result in the development of new antigenic variants during infection. Infect Immun 2000; 68; 1319-1327.

294.Szer IS, Taylor E, Steere AC. The long-term course of Lyme arthritis in children. N Engl J Med. 1991 Jul $18 ; 325(3): 159-63$.

295. Thomas V, Anguita J, Barthold SW, Fikrig E. Coinfection with Borrelia burgdorferi and the agent of human granulocytic ehrlichiosis alters murine immune responses, pathogen burden, and severity of Lyme arthritis. Infect Immun. 2001; 69: 3359-3371.

296. Tracy KE, Baumgarth N. Borrelia burgdorferi manipulates innate and adaptive immunity to establish persistence in rodent reservoir hosts. Front. Immunol. 2017;8:116.

297. Trevisan G, Cinco M, Agolzer A. Roseolar lesions in Lyme disease: Isolation of the causative agent. Int J Dermatol 1992;31:507-508.

298. Tunev SS, Hastey CJ, Hodzic E, Feng S, Barthold SW, Baumgarth N. Lymphoadenopathy during Lyme borreliosis is caused by spirochete migration-induced specific B cell activation. PLoS Pathog. 2011 May;7(5):e1002066.

299. Valesová M, Trnavský K, Hulínská D, Alusík S, Janousek J, Jirous J. Detection of Borrelia in the synovial tissue from a patient with Lyme borreliosis by electron microscopy. J Rheumatol. 1989;16: 1502-1505.

300. Valesová H, Mailer J, Havlik J, Hulínská, D, Hercogová. Long-term results in patients with Lyme arthritis following treatment with ceftriaxone. Infection. 1996 (Jan-Feb); 24(1): 98-102.

301. Vartiovaara I. Living with Lyme. Lancet 1995; 345: 842-844.

302. Vegsundvåg J, Nordeide J, Reikvam A, Jenum P. Late cardiac manifestation of infection with Borrelia burgdorferi (Lyme disease). BMJ. 1993 Jul 17;307(6897):173.

303. Walberg P, Granlund H, Nyman D, Panelius J, Seppälä I. Treatment of late Lyme borreliosis. J Infection. 1994; 29: 255-261.

304. Waniek C, Prohovnik I, Kaufman MA, Dwork AJ. Rapid progressive frontal-type dementia associated with Lyme disease. J Neuropsychiatry Clin Neurosci. 1995; 7: 345-347. (B. burgdorferi detected at autopsy).

305. Wang P, Gartenhaus R, Sood SK, DeVoti J, Singer C, Dorante G, Hilton E. Detection of Borrelia DNA in circulating monocytes as evidence of persistent Lyme disease. J Spiro Tick-borne Dis. 2000; 7: 16-19. 
306. Weber K. Treatment failure in erythema migrans: a review. Infection. 1996; 24: 73-75.

307. Weis JJ, Yang L, Seiler KP, Silver RM. Pathological manifestations in murine Lyme disease: association with tissue invasion and spirochete persistence. Clin Infect Dis 1997 (Suppl 1): S18-24.

308. Wienecke R, Zoechling N, Neubert U. Molecular subtyping of Borrelia burgdorferi in erythema migrans and acrodermatitis chronica atrophicans. J Invest Dermatol 1994; 103; 19-22. [chronic Lyme borreliosis].

309.Xu Q, Mcshan K, Liang FT. Modification of Borrelia burgdorferi to overproduce OspA or VlsE alters its infectious behaviour. Microbiology 2008; 154: 3420-3429.

310. Yang L, Weis JH, Eichwald E, Kolbert CP, Persing DH, Weis JJ. Heritable susceptibility to severe Borrelia burgdorferi-induced arthritis is dominant and is associated with persistence of large numbers of spirochetes in tissues. Infect Immun 1994; 62: 492-500.

311.Young D, Hussell T, Dougan G. Chronic bacterial infections: living with unwanted guests. Nat Immunol 2002 Nov; 3(11): 1026-1032.

312. Yrjänäinen H, Hytönen J, Söderström KO, Oksi J, Hartiala K, Viljanen MK. Persistent joint swelling and Borreliaspecific antibodies in Borrelia garinii-infected mice after eradication of vegetative spirochetes with antibiotic treatment. Microbes Infect 2006;8: 2044-2051. [persistence if Bb in mice]

313. Yrjänäinen H, Hytönen J, Song XY, Oksi J, Hartiala K, Viljanen MK. Anti-tumor necrosis factor-alpha treatment activates Borrelia burgdorferi spirochetes in 4 weeks after ceftriaxone treatment in $\mathrm{C} 3 \mathrm{H} / \mathrm{He}$ mice. $\mathrm{J}$ Infect Dis 2007;195: 1489-1496.

314. Yrjänäinen H, Hytönen J, Hartiala P, Oksi J, Viljanen MK. Persistence of borrelial DNA in the joints of Borrelia burgdorferi-infected mice after ceftriaxone treatment. APMIS 2010;118(9): 665-673.

315.Zajkowska JM, Hermanowska-Szpakowicz T. New aspects of the pathogenesis of Lyme disease. Przegl Epidemiol 2002;56 (Suppl 1):57-67.

316.Zalaudek I, Leinweber B, Kerl H, Müllegger RR. Acrodermatitis chronica atrophicans in a 15-year-old girl misdiagnosed as venous insufficiency for 6 years. J Am Acad Dermatol. 2005 Jun;52(6):1091-4.

317.Zeidner NS, Dolan MC, Massung R, Piesman J, Fish D. Coinfection with Borrelia burgdorferi and the agent of human granulocytic ehrlichiosis suppresses IL-2 and IFN gamma production and promotes an IL-4 response in $\mathrm{C} 3 \mathrm{H} / \mathrm{HeJ}$ mice. Parasite Immunol. 2000; 22:581-588.

318.Zhang JR, Hardham JM, Barbour AG, and Norris SJ. Antigenic variation in Lyme disease borreliae by promiscuous recombination of VMP-like sequence cassettes. Cell 1997; 89: 275-285.

319.Zhang Y. Persisters, persistent infections and the Yin-Yang model. Emerg Microbes Infect 2014;3:e3.

320.Zimering JH, Williams MR, Eiras ME, Fallon BA, Logigian EL, Dworkin RH et al. Acute and chronic pain associated with Lyme borreliosis: clinical characteristics and pathophysiologic mechanisms. Pain. 2014 Aug;155(8):1435-1438.

321.Ziska MH, Donta ST, Demarest FC. Physician preferences in the diagnosis and treatment of Lyme disease in the United States. Infection 1996; 24: 182-186.

\section{Neuropsychiatric Symptoms and Lyme/Tickborne Diseases}

1. Aalto A, Sjowall J, Davidsson L, Forsberg P, Smedby O. Brain magnetic resonance imaging does not contribute to the diagnosis of chronic neuroborreliosis. Acta Radiol 2007; 48: 755-762. [white matter hyperintensities or basal ganglia lesions].

2. Ackermann R, Rehse-Kupper B, Gollmer E, Schmidt R.Chronic neurologic manifestations of erythema migrans borreliosis. Ann N Y Acad Sci. 1988;539:16-23.

3. Adams WV, Rose CD, Eppes SC, Klein JD. Long-term cognitive effects of Lyme disease in children. Appl Neuropsychol 1999;6(1):39-45

4. Alaedini A, Latov N Antibodies against OspA epitopes of Borrelia burgdorferi cross-react with neural tissue. J Neuroimmunol. 2005 Feb;159(1-2):192-5. Epub 2004 Nov 26.

5. Askenazy F, Dor E, Benoit M, Dupuis G, Serret S, Myquel M, et al. Catatonia in a 14 year-old girl: treatment with clorazepam and carbamazepine, a 10-year follow-up. Encephale. 2010 Feb;36(1):46-53.

6. Banerjee R, Liu JJ, Minhas HM. Lyme neuroborreliosis presenting with alexithymia and suicide attempts. J Clin Psychiatry. 2013 Oct;74(10):981.

7. Bannwarth, A. Zur klinik und pathogenese der chronischen lymphocytären meningitis. Arch Psychiatr Nervenkr. 1944;117: 161-185. 
8. Bar KJ, Jochum T, Hager F, Meissner W, Sauer H. Painful hallucinations and somatic delusions in a patient with the possible diagnosis of neuroborreliosis. Clin J Pain. 2005 Jul-Aug;21(4):362-3.

9. Barnett W, Sigmund D, Roelcke U, Mundt C. Endogenous paranoid-hallucinatory syndrome caused by Borrelia encephalitis Nervenarzt 1991 Jul;62(7):445-7 [German]

10. Battaglia H, Alvarez G, Mercau A, Fay M, Campodonico M. Psychiatric symptomatology associated with presumptive Lyme disease: Clinical evidence. J Spiro Tick-borne Dis 2000; 7: 22-25.

11. Bechter K. Diagnosis of infectious or inflammatory psychosyndromes. Open Neurol J. 2012; 6:113-118.

12. Belman AL, Iyer M, Coyle PK, Dattwyler R. Neurologic manifestations in children with North American Lyme disease. Neurology. 1993 Dec;43(12):2609-14.

13. Belman AL, Iyer M, Coyle PK, Dattwyler R. Neurologic manifestations in children with North American Lyme disease. Neurology. 1993 Dec;43(12):2609-14.

14. Benke T, Gasse T, Hittmair-Delazer M, Schmutzhard E. Lyme encephalopathy: long-term neuropsychological deficits years after acute neuroborreliosis. Acta Neurol Scand. 1995 May;91(5):353-7.

15. Berman DS, Wenglin BD. Complaints attributed to chronic Lyme disease: depression or fibromyalgia? Am J Med. 1995 Oct;99(4):440.

16. Bertholon P, Cazorla C, Carricajo A, Oletski A, Laurent B. Bilateral sensorineural hearing loss and cerebellar ataxia in the case of late stage Lyme disease. Braz J Otorhinolaryngol. 2012 Dec;78(6):124.

17. Bertrand E, Szpak GM, Pilkowski E, Habib N, Lipczynska-Lojkowska W, Rudnicka A, Tylewska-Wierzbanowska S, Kulczycki J. Central nervous system infection caused by Borrelia burgdorferi. Clinico-pathological correlation of three post-mortem cases. Folia Neuropathol 1999;37:43-51.

18. Biesiada G, Czapiel J, Sobczyk-Krupiarz I, Garlicki A, Mach T. Neuroborreliosis with extrapyramidal symptoms: a case report. Pol Arch Med Wewn. 2008 May;118(5):314-7.

19. Binalsheikh IM, Griesemer D, Wang S, Alvarez-Altalef R. Lyme neuroborreliosis presenting as Alice in Wonderland syndrome. Pediatr Neurol. 2012; 46:185-186.

20. Bitam I, Raoult D. Other tick-borne diseases in Europe. Curr Probl Dermatol. 2009;37:130-154.

21. Blanc F; GEBLY. Neurologic and psychiatric manifestations of Lyme disease. Med Mal Infect. 2007 JulAug;37(7- 8):435-45.

22. Bloom BJ, Wyckoff PM, Meissner HC, Steere AC. Neurocognitive abnormalities in children after classic manifestations of Lyme disease. Pediatr Infect Dis J 1998; 17(3):189-96.

23. Bransfield RC. The psychoimmunology of Lyme/tick-borne diseases and its association with neuropsychiatric symptoms. Open Neurol J. 2012; 6:88-93.

24. Bransfield RC, Wulfman JS, Harvey WT, Usman AI. The association between tick-borne infections, Lyme borreliosis and autism spectrum disorders. Med Hypotheses. 2008;70(5):967-74.

25. Bransfield RC. Case report: Lyme disease and complex partial seizures. J Spiro Tick-borne Dis. 1999; 6:123-125 .

26. Bransfield RC. Diagnosis, treatment, and prevention of Lyme disease. JAMA. 1998 Sep 23-30;280(12):1049; author reply 1051 .

27. Bransfield RC. Lyme disease, comorbid tick-borne diseases, and neuropsychiatric disorders. Psychiatr Times. 2007 Dec; 24(14)59-61

28. Bransfield RC. Preventable cases of autism: relationship between chronic infectious disease and neurological outcome. Pediatr Health. 2009; 3(2):125-140.

29. Bransfield RC. Relationship of inflammation and autoimmunity to psychiatric sequelae in Lyme disease. Psychiatr Ann. 2012; 42(9):337-41

30. Bransfield RC. The diagnosis of Lyme disease. Hosp Pract (Minneap). 1996 Aug 15;31(8):35, 40.

31. Bransfield RC, Kuhn M. Autism and Lyme disease. JAMA. 2013 Aug 28;310(8):856-7.

32. Bransfield RC. The psychoimmunology of Lyme/tick-borne diseases and its association with neuropsychiatric symptoms. Open Neurol J. 2012; 6: 88-93.

33. Bransfield RC. Intrusive symptoms and infectious encephalopathies. Neurol Psychiatr Brain Res. 2016; $22(1)$ : 3-4.

34. Breitschwerdt EB, Mascarelli PE, Schweickert LA, Ricardo G. Maggi RG, Hegarty BC, Bradley JM, Woods CW. Hallucinations, sensory neuropathy, and peripheral visual deficits in a young woman infected with Bartonella koehlerae. J Clin Microbiol. 2011; 49: 3415-3417

35. Breitschwerdt EB, Maggi RG, Cadenas MB, Vissotto de Paiva Diniz PP. A groundhog, a novel Bartonella sequence, and my father's death. Emerg Infect Dis. 2009 Aug;15(12): 2080-6.

36. Breitschwerdt EB. Bartonellosis, One Health and all creatures great and small. Vet Dermatol. 2017 Feb;28(1):96e21. 
37. Breitschwerdt EB. Maggi RG, Nicholson WL, Cherry NA, Woods CW. Bartonella sp. bacteremia in patients with neurological and neurocognitive dysfunction. J Clin Microbiol. 2008;46(9):2856-2861.

38. Brinck T, Hansen K, Olesen J. Headache resembling tension-type headache as the single manifestation of Lyme neuroborreliosis. Cephalalgia. 1993 Jun;13(3):207-9.

39. Brown JS Jr. Geographic correlation of schizophrenia to ticks and tick-borne encephalitis. Schizophr Bull 1994;20(4):755-75.

40. Burakgazi AZ. Lyme disease -induced polyradiculopathy mimicking amyotrophic lateral sclerosis. Int J Neurosci. 2014 Nov;124(11):859-62.

41. Burns RB, Hartman EE. A 58-year-old man with a diagnosis of chronic Lyme disease, 1 year later. JAMA. 2003 Dec 24;290(24):3247.

42. Caliendo MV, Kushon DJ, Helz JW. Delirium and Lyme disease. Psychosomatics. 1995 Jan-Feb;36(1):69-74.

43. Cassarino DS, Quezado MM, Ghatak NR, Duray PH. Lyme-associated parkinsonism: a neuropathologic case study and review of the literature. Arch Pathol Lab Med. 2003 Sep;127(9):1204-6.

44. Chabria SB, Lawrason J. Altered mental status, an unusual manifestation of early disseminated Lyme disease: A case report. J Med Case Reports. 2007 Aug 9;1:62.

45. Chan L, Reilly KM, Snyder HS. An unusual presentation of cat scratch encephalitis. J Emerg Med. 1995 NovDec;13(6):769-72.

46. Chandra AM, Keilp JG, Fallon BA. Correlates of perceived health-related quality of life in post-treatment Lyme encephalopathy. Psychosomatics. 2013 Nov-Dec;54(6):552-9.

47. Cheherama M, Zagardo MT, Koski CL Subarachnoid hemorrhage in a patient with Lyme disease. Neurology. 1997;48:520-523

48. Cintron R, Pachner AR. Spirochetal diseases of the nervous system. Curr Opin Neurol. 1994 Jun;7(3):217-22.

49. Clark JR, Carlson RD, Sasaki CT, Pachner AR, Steere AC. Facial paralysis in Lyme disease. Laryngoscope. 1985 Nov;95(11):1341-5.

50. Corral I, Sanchis G, Garcia-Ribas G, Quereda C, Escudero R, de Blas G. Demyelinating polyradiculitis in neuroborreliosis. Neurologia. 1995 Feb;10:110-113.

51. Cowley G, Underwood A. A disease in disguise. Lyme can masquerade as migraine, or as madness. Newsweek. 2004 Aug 23;144(8):62.

52. Coyle PK, Deng Z, Schutzer SE, Belman AL, Benach J, Krupp LB, Luft B. Detection of Borrelia burgdorferi antigens in cerebrospinal fluid. Neurology 1993;43:1093-1097.

53. Coyle PK, Schutzer SE, Deng Z, Krupp LB, Belman AL, Benach JL, Luft BJ. Detection of Borrelia burgdorferispecific antigen in antibody-negative cerebrospinal fluid in neurologic Lyme disease. Neurology. 1995 Nov;45(11):2010-5.

54. Créange A. Clinical manifestations and epidemiological aspects leading to a diagnosis of Lyme borreliosis: neurological and psychiatric manifestations in the course of Lyme borreliosis Med Mal Infect. 2007 Jul-Aug;37(78):532-9. Epub 2007 Mar 26.

55. Császár T, Patakfalvi A. Differential diagnostic problems in Lyme disease - Borrelia infection resulting in acute exogenous psychosis. Orv Hetil. 1994 Oct 9;135(41):2269-71.

56. Dattwyler RJ, Halperin JJ. Failure of tetracycline therapy in early Lyme disease. Arthritis Rheum. 1987 Apr;30(4):448- 50.

57. Dekonenko EP, Umanskii KG, Virich IE, Kupriianova LV, Rudometov, IuP, Bagrov FI The basic syndromes of neurological disorders in Lyme borreliosis. Ter Arkh. 1995; 67(11):52-53.

58. Donta ST, Noto RB, Vento JA. SPECT brain imaging in chronic Lyme disease. Clin Nucl Med. 2012 Sep;37(9):e219-22.

59. Druschky K, Stefan H, Grehl H, Neundörfer B. Secondary normal pressure hydrocephalus. A complication of chronic neuroborreliosis. Nervenarzt. 1999 Jun;70(6):556-9.

60. Dryden MS, Saeed K, Ogborn S, Swales P. Lyme borreliosis in southern United Kingdom and a case for a new syndrome, chronic arthropod-borne neuropathy. Epidemiol Infect. 2015 Feb;143(3):561-72.

61. Dupeyron A, Lecocq J, Jaulhac B, Isner-Horobeti ME, Vautravers P, Cohen-Solal J, et al. Sciatica, disk herniation, and neuroborreliosis. A report of four cases. Joint Bone Spine. 2004; 71: 433-437.

62. Dupuis MJ. Multiple neurologic manifestations of Borrelia burgdorferi infection. Rev Neurol (Paris) 1988;144(12):765- 75

63. Edelstyn NM, Hunter B, Ellis SJ. Bilateral dorsolateral thalamic lesions disrupts conscious recollection. Neuropsychologia. 2006;44(6):931-8. Epub 2005 Oct 25. 
64. Eikeland R, Mygland A, Herlofson K, Ljøstad U. European neuroborreliosis: quality of life 30 months after treatment. Acta Neurol Scand. 2011Nov;124(5):349-54.

65. Elkins LE, Pollina DA, Scheffer SR, Krupp LB. Psychological states and neuropsychological performances in chronic Lyme disease. Appl Neuropsychol 1999;6(1):19-26.

66. Engman M-L, Lindström K, Sallamba M, Hertz C, Sundberg B, Hansson ME, et al. One-year follow-up of tickborne central nervous system infections in childhood. Pediatric Infect Dis J. 2012; 31(6): 570-4.

67. Eskow E, Rao RV, Mordechai E. Concurrent infection of the central nervous system by Borrelia burgdorferi and Bartonella henselae: evidence for a novel tick-borne disease complex. Arch Neurol. 2001 Sep;58(9):1357-63.

68. Etienne M, Carvalho P, Fauchais AL, Pestel-Caron M, Doucet J, Chassagne P. Lyme neuroborreliosis revealed as a normal pressure hydrocephalus: a cause of reversible dementia. J Am Geriatr Soc. 2003 Apr;51(4):579-80.

69. Fallon BA, Schwartzberg M, Bransfield R, Zimmerman B, Scotti A, Weber CA, Liebowitz MR. Late-stage neuropsychiatric Lyme borreliosis. Case reports. Psychosomatics 1995; 36: 295-300.

70. Fallon BA, Bird H, Hoven C, Cameron D, Liebowitz MR, Shaffer S. Psychiatric aspects of Lyme disease in children and adolescents: A community epidemiologic study in Westchester, New York. J Spiro Tick-borne Dis 1994; 1:98-100

71. Fallon BA, Das S, Plutchok JJ, Tager F, Liegner K, Van Heertum R. Functional brain imaging and neuropsychological testing in Lyme disease. Clin Infect Dis 1997; 25 (Suppl 1):S57-63

72. Fallon BA, Javitch JA, Hollander E, Liebowitz MR. Hypochondriasis and obsessive compulsive disorder: overlaps in diagnosis and treatment. J Clin Psychiatry. 1991: 52(11):457-60.

73. Fallon BA, Keilp J, Prohovnik I, Heertum RV, Mann JJ. Regional cerebral blood flow and cognitive deficits in chronic Lyme disease. J Neuropsychiatry Clin Neurosci. 2003 Summer;15(3):326-32.

74. Fallon BA, Kochevar JM, Gaito A, Nields JA. The underdiagnosis of neuropsychiatric Lyme disease in children and adults. Psychiatr Clin North Am. 1998; 21: 693-703

75. Fallon BA, Levin ES, Schweitzer PJ, Hardesty D. Inflammation and central nervous system Lyme disease. Neurobiol Dis. 2010 Mar;37(3):534-41.

76. Fallon BA, Lipkin RB, Corbera KM, Yu S, Nobler MS, Keilp JG, Petkova E, Lisanby SH, Moeller JR, Slavov I, Van Heertum R, Mensh BD, Sackeim HA. Regional cerebral blood flow and metabolic rate in persistent Lyme encephalopathy. Arch Gen Psychiatry. 2009 May;66(5):554-63.

77. Fallon BA, Nields JA Acute disseminated encephalomyelitis [letter]. J Neuropsychiatry Clin Neurosci 1998 Summer;10(3):366-7

78. Fallon BA, Nields JA, Burrascano JJ, Liegner K, DelBene D, Liebowitz MR. The neuropsychiatric manifestations of Lyme Borreliosis. Psychiatr Q. 1992; 63: 95-117.

79. Fallon BA, Nields JA, Parsons B, Liebowitz MR, Klein DF. Psychiatric manifestations of Lyme borreliosis. J Clin Psychiatry 1993 Jul;54(7):263-8

80. Fallon BA, Nields JA. Lyme Disease: A neuropsychiatric illness. Am J Psychiatry 1994 Nov;151(11):1571-83

81. Fallon BA, Petkova E, Keilp JG, Britton CB. Ongoing discussion about the US clinical Lyme trials. Am J Med. 2014 Feb;127(2):e7.

82. Fallon BA, Keilp JG, Corbera KM, Petkova K, Britton CB, Dwyer E, et al. A randomized, placebo-controlled trial of repeated IV antibiotic therapy for Lyme encephalopathy. Neurology 2008; 70: 992-1003.

83. Fallon BA, Petkova E, Keilp JG, Britton CB. A reappraisal of the U.S. clinical trials of post-treatment Lyme disease syndrome. Open Neurol J. 2012; 6:79-87.

84. Fallon BA, Schwartzberg M, Bransfield R, Zimmerman B, Scotti A, Weber CA, Liebowitz MR. Late-stage neuropsychiatric Lyme borreliosis: Differential diagnosis and treatment. Psychosomatics 1995;36:295-300

85. Fallon BA, Vaccaro B, Romano M, Clemente D. Neuropsychiatric and neuropathologic aspects of Lyme disease. Psychiatric Annals. 2006;36:120-128.

86. Fallon BA, Weis N, Tager F, Fein L, Liegner K, Liebowitz MR. Repeated antibiotic therapy in chronic Lyme disease. J Spiro Tick-borne Dis. 1999; 6: 1-9.

87. Fallon BA, Keilp J, Prohovnik I, Heertum RV, Mann JJ. Regional cerebral blood flow and cognitive deficits in chronic Lyme disease. J Neuropsychiatry Clin Neurosci 2003; 15: 326-332.

88. Fallon BA, Lipkin RB, Corbera KM, Yu S, Nobler MS, Keilp JG, Petkova E, Lisanby SH, Moeller JR, Slavov I, Van Heertum R, Mensh BD, and Sackeim HA. Regional cerebral blood flow and metabolic rate in persistent Lyme encephalopathy. Arch Gen Psychiatry 2009; 66: 554-563.

89. Farshad-Amacker NA, Scheffel H, Frauenfelder T, Alkadhi H. Brainstem abnormalities and vestibular nerve enhancement in acute neuroborreliosis. BMC Research Notes 2013; 6: 551. 
90. Ferroir JP, Reignier A, Nicolle MH, Guillard A. Meningoradiculoencephalitis in Lyme disease. A case with major regressive mental disorders. Presse Med. 1988 Apr 16;17(14):697.

91. Fritzsche M. Seasonal correlation of sporadic schizophrenia to Ixodes ticks and Lyme borreliosis. Int J Health Geogr. 2002; 1:2

92. Fritzsche M. Geographical and seasonal correlation of multiple sclerosis to sporadic schizophrenia. Int J Health Geogr. 2002 Dec 20;1(1):5.

93. Frykholm BO. On the question of infectious aetiologies for multiple sclerosis, schizophrenia and the chronic fatigue syndrome and their treatment with antibiotics. Med Hypotheses 2010 Apr;74(4):758-60.

94. Gampourou F, Taithe F, Moisset X, Clavelou P. Seronegative Lyme neuroborreliosis in a patient treated by rituximab. Rev Neurol (Paris). 2016 Feb;172(2):166-7.

95. Garakani A, Mitton AG. New-onset panic, depression with suicidal thoughts, and somatic symptoms in a patient with a history of Lyme disease. Case Rep Psychiatry. 2015;2015:457947.

96. Garcia-Monco JC, Benach JL. Lyme neuroborreliosis. Ann Neurol 1995 Jun; 37: 691-70.

97. García-Moncó JC, Benach JL Neurological manifestations of Lyme disease. Enferm Infec Microbiol Clin. 1989 Nov;7(9):501-6.

98. Garcia-Monco JC, Villar BF, Alen JC, Benach JL. Borrelia burgdorferi in the central nervous system: experimental and clinical evidence for early invasion. J Infect Dis. 1990 Jun;161(6):1187-93.

99. García-Moreno JM, Izquierdo G, Chacón J, Angulo S, Borobio MV. Neuroborreliosis in a patient with progressive supranuclear paralysis. An association or the cause? Rev Neurol. 1997 Dec;25(148):1919-21.

100. Gasse T, Murr C, Meyersbach P, Schmutzhard E, Wachter H, Fuchs D. Neopterin production and tryptophan degradation in acute Lyme neuroborreliosis versus late Lyme encephalopathy. Eur J Clin Chem Clin Biochem. 1994 Sep;32(9):685-9.

101. Gaudino EA, Coyle PK, Krupp LB. Post-Lyme syndrome and chronic fatigue syndrome. Neuropsychiatric similarities and differences. Arch Neurol 1997 Nov;54(11):1372-6

102. Gentile I, Zappulo E, Militerni R, Pascotto A, Borgia G, Bravaccio C. Etiopathogenesis of autism spectrum disorders: Fitting the pieces of the puzzle together. Med Hypotheses. 2013 Jul;81(1):26-35.

103. George TI, Manley G, Koehler JE, Hung VS, McDermott M, Bollen A. Detection of Bartonella henselae by polymerase chain reaction in brain tissue of an immunocompromised patient with multiple enhancing lesions. Case report and review of the literature. J Neurosurg. 1998 Oct;89(4):640-4.

104. Gerstenblith TA, Stern TA. Lyme disease: a review of its epidemiology, evaluation, and treatment. Psychosomatics. 2014 Sep-Oct;55(5):421-9.

105. Gheorghiev C, De Montleau F, Defuentes G. Alcohol and epilepsy: A case report between alcohol withdrawal seizures and neuroborreliosis. Encephale 2011 Jun;37(3):231-7.

106. Greenberg HE, Ney G, Scharf SM, Ravdin L, Hilton E. Sleep quality in Lyme disease. Sleep. 1995 Dec;18(10):9126.

107. Greenberg R. Infections and childhood psychiatric disorders: Tick-borne illness and bipolar disorder in youth. Bipolar Disord. 2017; 3:1.

108. Greenblatt D, Krupp LB, Belman AL Parainfectious meningo-encephalo-radiculo-myelitis (cat scratch disease, Lyme borreliosis, brucellosis, botulism, legionellosis, pertussis, mycoplasma). Handb Clin Neurol 2013; 112: 1195-207.

109. Grzywa A, Karakuła H, Górecka J, Chuchra M. Delusional disorders in the course of tick-born encephalitis and borreliosis in patients with hemophilia A and posttraumatic epilepsy--diagnostic and therapeutic difficulties Pol Merkur Lekarski. 2004 Jan;16(91):60- 3. Polish.

110. Gueglio B, Raffi F, Marjolet M. Lyme neuroborreliosis of mental manifestation. Apropos of a case. Rev Med Interne. 1996;17(7):599. [French]

111. Gustaw K, Beltowska K, Dlugosz E. Co-existance of toxoplasmosis and neuroborreliosis - a case report. Ann Agric Environ Med. 2005;12(2):305-8.

112. Gustaw K, Beltowska K, Studzinska MM. Neurological and psychological symptoms after the severe acute neuroborreliosis. Ann Agric Environ Med 2001;8(1):91-4

113. Gustaw-Rothenberg K. Cognitive impairments after tick-borne encephalitis. Dement Geriatr Cogn Disord. 2008;26:165-168.

114. Haass A. Lyme neuroborreliosis. Curr Opin Neurol. 1998;11:253-258.

115. Hájek T, Libiger J, Janovská D, Hájek P, Alda M, Höschl C. Clinical and demographic characteristics of psychiatric patients seropositive for Borrelia burgdorferi. Eur Psychiatry. 2006 Mar;21(2):118-22.

116. Hajek T, Paskova B, Janovska D, Bahbouh R, Hajek P, Libiger J, Hoschl C. Higher prevalence of antibodies to Borrelia burgdorferi in psychiatric patients than in healthy subjects. Am J Psychiatry 159:297-301, February 2002. 
117. Halperin JJ, Luft BJ, Anand AK, Roque CT, Alvarez O, Volkman DJ, Dattwyler RJ. Lyme neuroborreliosis: central nervous system manifestations. Neurology. 1989 Jun;39(6):753-9.

118. Halperin JJ. Prolonged Lyme disease treatment: enough is enough. Neurology 2008; 70(13): 986-987.

119. Harvey WT, Martz D. Motor neuron disease recovery associated with IV ceftriaxone and anti-Babesia therapy. Acta Neurol Scand 2007: 115: 129-131.

120. Hassett AL, Radvanski DC, Buyske S, Savage SV, and Sigal LH. Psychiatric comorbidity and psychological factor in patients with "chronic Lyme disease.” Am J Med. 2009; 122(9): 843-850.

121. Hassett AL, Radvanski DC, Buyske S, Savage SV, Gara M, Escobar JI, Sigal LH Role of psychiatric comorbidity in chronic Lyme disease. Arthritis Rheum. 2008 Dec 15;59(12):1742-9.

122. Helon B, Tluczek TW, Buczyjan A, Adamczyk-Helon A, Wojnarowicz M, Mikula R, Cicinski P, Bojarska J. Polymorphic mental disorders in the course of Lyme borreliosis--case study. Psychiatr Pol. 2009 May-Jun;43(3):35361.

123. Hernandez-Albujar S, Rubio G, Gopar J, Galeote G, Rey R, Gil A. Parasitic delirium in patient with multiorganic pathology: a complex situation. An Med Interna 1996 Nov;13(11):549-51.

124. Hess A, Buchmann J, Zettl UK, Henschel S, Schlaefke D, Grau G, Benecke R. Borrelia burgdorferi central nervous system infection presenting as an organic schizophrenialike disorder. Biol Psychiatry 1999;45(6):795.

125. Hildenbrand, Craven DE, Jones R, Nemeskal P. Lyme neuroborreliosis: Manifestations of a rapidly emerging zoonosis. Am J Neuroradiol 2009;30:1079-87.

126. Hodgson R, Belgamwar R, Al-tawarah Y, MacKenzie G The use of atypical antipsychotics in the treatment of schizophrenia in North Staffordshire. Hum Psychopharmacol. 2005;20:141-7.

127. Holtze M, Mickiene' A. Atlas A, Lindquist L, Schwieler L. Elevated cerebrospinal fluid kynurenic acid levels in patients with tick-borne encephalitis. J Intern Med. 2012; 272: 394-401.

128. Hovius JW, de Wever B, Sohne M, Brouwer MC, Coumou J, Wagemakers A, et al. A case of meningoencephalitis by the relapsing fever spirochaete Borrelia miyamotoi in Europe. Lancet 2013;382:658.

129. Hurley RA, Taber KH. Acute and chronic Lyme disease: Controversies for neuropsychiatry. J Neuropsychiatry Clin Neurosci 2008;20(1):iv-6.

130. Iero I, Elia M, Cosentino FI, Lanuzza B, Spada RS, Toscano G, Tripodi M, Belfiore A, Ferri R. Isolated monolateral neurosensory hearing loss as a rare sign of neuroborreliosis. Neurol Sci. 2004 Apr;25(1):30-3.

131. Imai DM, Barr BC, Daft B, Bertone JJ, Feng S, Hodzic E, Johnston JM, Olsen KJ, Barthold SW. Lyme neuroborreliosis in two horses. Vet Pathol 2011; 48: 1151-1157.

132. Issakainen J, Gnehm HE, Lucchini GM, Zbinden R Value of clinical symptoms, intrathecal specific antibody production and PCR in CSF in the diagnosis of childhood Lyme neuroborreliosis. Klin Padiatr 1996 May-Jun; 208: 106-109.

133. Izquierdo G, Aguilar J, Barranquero A, Navarro G, Borobio MV, Angulo S, Domínguez I, Quesada MA. Positive anti-Borrelia antibodies in patients with clinical manifestations compatible with neuroborreliosis. Neurologia. 1992 Feb;7(2):50-4. Spanish.

134. Jacek E, Fallon BA, Chandra A, Crow MK, Wormser GP, Alaedini A. Increased IFN $\alpha$ activity and differential antibody response in patients with a history of Lyme disease and persistent cognitive deficits. J Neuroimmunol. 2013 Feb 15;255(1-2):85-91.

135. James FM, Engiles JB, Beech J. Meningitis, cranial neuritis, and radiculoneuritis associated with Borrelia burgdorferi infection in a horse. J Am Vet Med Assoc 2010; 237: 1180-1185.

136. Jarskog LF, Mattioli MA, Perkins DO, Lieberman JA. First-episode psychosis in a managed care setting: clinical management and research. Am J Psychiatry. 2000 Jun;157(6):878-84.

137. Jovanovic J, Cvjetkovic D, Vukadinov J. Lyme disease--neuroborreliosis. Med Pregl. 1995;48(3-4):120-2.

138. Juchnowicz D, Rudnik I, Czernikiewicz A, Zajkowska J, Pancewicz SA. Mental disorders in the course of lyme borreliosis and tick borne encephalitis. Przegl Epidemiol 2002;56 Suppl 1:37-50 [Polish]

139. Kaiser B. Neuroborreliosis. J Neurol. 1998; 245:247-255

140. Kanjwal K, Karabin B, Kanjwal Y, Grubb BP. Postural orthostatic tachycardia syndrome following Lyme disease. Cardiol J. 2011;18(1):63-6.

141. Kaplan A. Neuropsychiatric masquerades. Psychiatr Times 2009 Feb; 26(2):1-8.

142. Kaplan RF, Jones-Woodward L, Workman K, Steere AC, Logigian EL, Meadows ME. Neuropsychological deficits in Lyme disease patients with and without other evidence of central nervous system pathology. Appl Neuropsychol. 1999;6(1):3-11. 
143. Kaplan RF, Jones-Woodward L. Lyme encephalopathy: a neuropsychological perspective. Semin Neurol. 1997 Mar;17(1):31-7.

144. Kaplan RF, Meadows ME, Vincent LC, Logigian EL, Steere AC. Memory impairment and depression in patients with Lyme encephalopathy: comparison with fibromyalgia and nonpsychotically depressed patients. Neurology. 1992 Jul;42(7):1263-7.

145. Karma A, Stenborg T, Summanen P, Immonen I, Mikkila H, and Seppala I. Long-term follow-up of chronic Lyme neuroretinitis. Retina 1996; 16: 505-509.

146. Karma A, Pirttilä TA, Viljanen MK, Lähde YE, Raitta CM. Secondary retinitis pigmentosa and cerebral demyelination in Lyme borreliosis. Br J Ophthalmol. 1993 Feb;77(2):120-2.

147. Karma A, Seppälä I, Mikkilä H, Kaakkola S, Viljanen M, Tarkkanen A. Diagnosis and clinical characteristics of ocular Lyme borreliosis. Am J Ophthalmol. 1995 Feb;119(2):127-35.

148. Keilp JG, Corbera K, Slavov I, Taylor MJ, Sackeim HA, Fallon BA. WAIS-III and WMS-III performance in chronic Lyme disease. J Int Neuropsychol Soc. 2006 Jan;12(1):119-29.

149. Keller TL, Halperin JJ, and Whitman M. PCR detection of Borrelia burgdorferi DNA in cerebrospinal fluid of Lyme neuroborreliosis patients. Neurology 1992; 43: 32-42.

150. Kepa L, Oczko-Grzesik B, Badura-Glombik T. Evaluation of cerebrospinal fluid serotonin (5-HT) concentration in patients with post-Lyme disease syndrome--preliminary study Przegl Epidemiol. 2008;62(4):793-800. Polish.

151. Kobayashi K, Mizukoshi C, Aoki T, Muramori F, Hayashi M, Miyazu K, Koshino Y, Ohta M, Nakanishi I, Yamaguchi N. Borrelia burgdorferi-seropositive chronic encephalomyelopathy: Lyme neuroborreliosis? An autopsied report. Dement Geriatr Cogn Disord. 1997 Nov-Dec;8(6):384-90.

152. Kohler J, Kern U, Kasper J, Rhese-Küpper B, Thoden U. Chronic central nervous system involvement in Lyme borreliosis. Neurology. 1988 Jun;38(6):863-7.

153. Kohler J. Lyme borreliosis in neurology and psychiatry. Fortschr Med. 1990 Apr 10;108(10):191-3, 197. Review. [German]

154. Kollikowski HH, Schwendemann G, Schulz M, Wilhelm H, Lehmann HJ. Chronic borrelia encephalomyeloradiculitis with severe mental disturbance: immunosuppressive versus antibiotic therapy. J Neurol. 1988 Jan;235(3):140-2.

155. Koola MM, Sullivan KM, Earl AK, Feldman SM, Richardson C, Vyas GR, et al. Undiagnosed Lyme disease in adults with schizophrenia. Schizophr Res. 2015;168(1-2):579-80.

156. Krause DL, Norbert Müller N. The relationship between Tourette's syndrome and infections. Open Neurol J. 2012; 6: 124-128.

157. Kristensson K. Microbes' roadmap to neurons. Nat Rev Neurosci. 2011 Jun;12(6):345-57.

158. Krüger H, Heim E, Schuknecht B, Scholz S. Acute and chronic neuroborreliosis with and without CNS involvement: a clinical, MRI, and HLA study of 27 cases. J Neurol. 1991 Aug;238(5):271-80.

159. Krupp LB, Hyman LG, Grimson R, Coyle PK, Melville P, Ahnn S, Dattwyler R, Chandler B. Study and treatment of post Lyme disease (STOP-LD): a randomized double masked clinical trial. Neurology. 2003 Jun 24;60(12):1923-30.

160. Krupp LB, Masur D, Schwartz J, Coyle PK, Langenbach LJ, Fernquist SK, Jandorf L, Halperin JJ. Cognitive functioning in late Lyme borreliosis. Arch Neurol. 1991 Nov;48(11):1125-9.

161. Krupp LB, Masur D, Schwartz J, Coyle PK, Langenback IJ, Fernquist SK. Cognitive functioning in late Lyme borreliosis. Arch Neurol 1999; 48: 1125-1129.

162. Kuhn M, Bransfield RC. Divergent opinions of proper Lyme disease diagnosis and implications for children comorbid with autism spectrum disorder. Med Hypotheses. 2014 Sep;83(3):321-5.

163. Kuhn M, Grave S, Bransfield R, Harris S. Long term antibiotic therapy may be an effective treatment for children comorbid with Lyme disease and autism spectrum disorder. Med Hypotheses. 2012 May;78(5):606-15.

164. Latov N, Wu AT, Chin RL, Sander HW, Alaedini A, Brannagran TH. Neuropathy and cognitive impairment following vaccination with the OspA protein of Borrelia burgdorferi. J Peripher Nerv Syst 2004; 9: 165-167.

165. Lawrence C, Lipton RB, Lowy RD, Coyle PK. Seronegative chronic relapsing neuroborreliosis. Eur Neurol 1995; 35(2): 113-117.

166. Leedy MJ, Jackson M, Callahan JL. Treating depression and compensatory narcissistic personality style in a man with chronic Lyme disease. Clinical Case Studies. 2007 Oct; 6(5):430-42.

167. Legatowicz-Koprowska M, Gziut AI, Walczak E, Gil RJ, Wagner T. Borreliosis--simultaneous Lyme carditis and psychiatric disorders--case report. Pol Merkur Lekarski. 2008 May;24(143):433-5. Polish.

168. Leslie TA, Levell NJ, Cutler SJ, Cann KJ, Smith ME, Wright DJ, Gilkes JJ, Robinson TW. Acrodermatitis chronica atrophicans: a case report and review of the literature. Br J Dermatol. 1994 Nov;131(5):687-93. 
169. Levenson JL Psychiatric issues in infectious diseases. Primary Psychiatry 2006;13(5):29-32.

170. Liegner KB, Duray P, Agricola M, Rosenkilde C, Yannuzzi LA, Ziska M, Tilton RC, Hulinska D, Hubbard J, Fallon BA. Lyme disease and the clinical spectrum of antibiotic responsive chronic meningoencephalomyelitides. J Spiro Tick-borne Dis 1997; 4: 61-73.

171. Listernick R. A 17-year-old boy previously diagnosed with chronic Lyme disease. Patient complained of low-grade fevers, headaches, pharyngitis, and suspected his mother was trying to poison him. Pediatr Ann. 2004 Aug;33(8):494-8.

172. Livengood JA and Gilmore RD, Jr. Invasion of human neuronal and glial cells by an infectious strain of Borrelia burgdorferi. Microbes and Infection. 2006; 8: 2832-2840.

173. Lobraico J, Butler A, Petrini J, Ahmadi R. New insights into stages of lyme disease symptoms from a novel hospitalbased registry. J Prim Care Community Health. 2014 Oct;5(4):284-7.

174. Logigian EL, Johnson KA, Kijewski MF, Kaplan RF, Becker JA, Jones KJ, Garada BM, Holman BL, Steere AC. Reversible cerebral hypoperfusion in Lyme encephalopathy. Neurology 1997 Dec;49(6):1661-70.

175. Logigian EL, Kaplan RF, Steere AC Chronic neurologic manifestations of Lyme disease. N Engl J Med. 1990 Nov 22;323(21):1438-44.

176. Logigian EL, Kaplan RF, Steere AC. Successful treatment of Lyme encephalopathy with intravenous ceftriaxone. J Infect Dis. 1999 Aug;180(2):377-83.

177. Luft BJ, Steinman CR, Neimark HC, Muralidhar B, Rush T, Finkel MF, Kundel M, Dattwyler RJ. Invasion of the CNS by Borrelia burgdorferi in acute disseminated infection. JAMA 1992; 267: 1364-1367.

178. Maillefert JF, Dardel P, Piroth C, Tavernier C. Mental nerve neuropathy in Lyme disease. Rev Rhum Engl Ed. 1997 Dec;64(12):855.

179. Maimone D, Villanova M, Stanta G, Bonin S, Malandrini A, Guazzi GC, Annunziata P. Detection of Borrelia burgdorferi DNA and complement membrane attack complex deposits in the sural nerve of a patient with chronic polyneuropathy and tertiary Lyme disease. Muscle Nerve. 1997 Aug;20(8):969-75.

180. Markeljević J, Sarac H, Rados M. Tremor, seizures and psychosis as presenting symptoms in a patient with chronic Lyme neuroborreliosis (LNB). Coll Antropol. 2011 Jan;35 Suppl 1:313-8.

181. Mascarelli PE, Maggi RG, Hopkins S, Mozayeni BR, Trull CL, Bradley JM, Hegarty BC, Breitschwerdt EB. Bartonella henselae infection in a family experiencing neurological and neurocognitive abnormalities after woodlouse hunter spider bites Parasites Vectors 2013; 6:98.

182. Matera G, Labate A, Quirino A, Lamberti AG, BorzÃ G, Barreca GS, Mumoli L, Peronace C, Giancotti A, Gambardella A, Foca A, Quattrone A. Chronic neuroborreliosis by B. garinii: an unusual case presenting with epilepsy and multifocal brain MRI lesions. New Microbiol. 2014 Jul;37(3):393-7

183. Mattsson N, Bremell D, Anckarsater R, Blennow K, Anckarsater H, Zetterberg H, Hagberg L. Neuroinflammation in Lyme neuroborreliosis affects amyloid metabolism. BMC Neurol. 2010 Jun 22;10(1):51

184. McAuliffe P, Brassard MR, Fallon B. Memory and executive functions in adolescents with posttreatment Lyme disease. Applied Neuropsych. 2008; 15:208-219

185. Merlo A, Weder B, Ketz E, Matter L. Locked-in state in Borrelia burgdorferi meningitis. J Neurol. 1989;236:305306.

186. Mikkilä H, Seppälä I, Leirisalo-Repo M, Immonen I, Karma A. The etiology of uveitis: the role of infections with special reference to Lyme borreliosis. Acta Ophthalmol Scand. 1997 Dec;75(6):716-9.

187. Mikkilä HO, Seppälä IJ, Viljanen MK, Peltomaa MP, Karma A. The expanding clinical spectrum of ocular Lyme borreliosis. Ophthalmology. 2000 Mar;107(3):581-7.

188. Miklossy J, Donta S, Mueller K, Nolte O, Perry G. Chronic or late Lyme neuroborreliosis: Present and future. Open Neurology J. 2012; 6:78.

189. Millner M. Neurologic manifestations of Lyme borreliosis in children. Wien Med Wochenschr 1995; 145 (7-8): 178182.

190. Möhrenschlager M, Köhn FM, Bauer M, Schaaf L, Hofmann H, Ring J. Late Lyme disease masking a nonfunctioning adenoma of the anterior lobe of the pituitary gland. Andrologia. 2002 Jun;34(3):162-3.

191. Mokry M, Flaschka G, Kleinert G, Kleinert R, Fazekas F, Kopp W. Chronic Lyme disease with an expansive granulomatous lesion in the cerebellopontine angle. Neurosurgery. 1990 Sep;27(3):446-51.

192. Morgen K, Martin R, Stone RD, Grafman J, Kadom N, McFarland HF, Marques A. FLAIR and magnetization transfer imaging of patients with post-treatment Lyme disease syndrome. Neurology. 2001 Dec 11;57(11):1980-5.

193. Morris G, Berk M, Walder K, Maes M. The putative role of viruses, bacteria, and chronic fungal biotoxin exposure in the genesis of intractable fatigue accompanied by cognitive and physical disability. Mol Neurobiol. 2016 May;53(4):2550-71. 
194. Moses JM, RS Riseberg, and JM Mansbach. Lyme disease presenting with persistent headache. Pediatrics 2003; 112 : 477-449.

195. Muller M, Retzl J, Plank E, Scholz H, Ziervogel H, Stanek G. Prevalence of Borrelia burgdorferi serum antibodies in 651 patients with predominantly neurologic diseases. Wien Klin Wochenschr. 1993;105(21):599-602.

196. Muller N, Riedel M, Straube A, Gunther W, Wilske B. Increased anti-streptococcal antibodies in patients with Tourette's syndrome. Psychiatry Res. 2000 Apr 24;94(1):43-9.

197. Murray R, Morawetz R, Kepes J, el Gammal T, LeDoux M. Lyme neuroborreliosis manifesting as an intracranial mass lesion. Neurosurgery. 1992 May;30(5):769-73.

198. Nadelman RB, Herman E, Wormser GP. Screening for Lyme disease in hospitalized psychiatric patients: prospective serosurvey in an endemic area. Mt Sinai J Med. 1997 Nov;64(6):409-12.

199. Newberg A, Hassan A, Alavi A. Cerebral metabolic changes associated with Lyme disease Nucl Med Commun 2002 August;23(8):773-777

200. Nicolson GL Chronic bacterial and viral Infections in neurodegenerative and neurobehavioral diseases. Lab Medicine. 2008;39(5):291-9.

201. Nicolson GL, Gann R, Nicolson NL, Haier J. Evidence for Mycoplasma, ssp., Chalmydia pneumoniae, and Human Herpes-virus 6 coinfections in blood of patients with autistic spectrum disorders. J Neurosci Res 2007 Apr;85(5):1143-8.

202. Nicolson GL, Haier J. Role of chronic bacterial and viral infections in neurodegenerative, neurobehavioral, psychiatric, autoimmune and fatiguing illnesses. Br J Med Pract. 2009:2(4)20-8.

203. Nields JA, Fallon BA, Jastreboff PJ. Carbamazepine in the treatment of Lyme disease-induced hyperacusis. J Neuropsychiatry Clin Neurosci 1999 Winter;11(1):97-9

204. Nields JA, Fallon BA. Differential diagnosis and treatment of Lyme disease with special reference to psychiatric practice. Directions Psychiatry, 1998; 18: 209-228.

205. Nields JA, Kueton JF. Tullio phenomenon and seronegative Lyme borreliosis. Lancet. 1991 Jul 13;338:128-9 .

206. Nocton JJ, Bloom BJ, Rutledge BJ, Persing DJ, Logigian EL, Schmid CH, Steere AC. Detection of Borrelia burgdorferi DNA by polymerase chain reaction in cerebrospinal fluid in Lyme neuroborreliosis. J. Infect Dis 1996; 174: 623-627.

207. Oglodek E, Mos D, Araszkiewicz A. Coexisting of borreliosis, depression and psoriasis--case report. Pol Merkur Lekarski. 2010 Jan;28(163):53-5.

208. Oksi J, Kalimo H, Marttila RJ, Marjarnaki M, Sonninen P, Nikoskelainen J, Viljanen MK. Inflammatory brain changes in Lyme Borreliosis. A report on three patients and review of literature. Brain. 1996; 119 (Pt 6) : $2143-2154$

209. Omasits M, Seiser A, Brainin M. Recurrent and relapsing course of borreliosis of the nervous system. Wien Klin Wochenschr. 1990;102(1):4-12. Review.

210. Pachner AR, Steere AC, Sigal LH, Johnson CJ. Antigen-specific proliferation of CSF lymphocytes in Lyme disease. Neurology. 1985 Nov;35(11):1642-4.

211. Pachner AR, Steere AC. The triad of neurologic manifestations of Lyme disease: meningitis, cranial neuritis, and radiculoneuritis. Neurology. 1985;35:47-53.

212. Pachner AR. Spirochetal diseases of the CNS. Neurol Clin. 1986;4:207-22.

213. Pachner AR. Borrelia burgdorferi in the nervous system: the new "great imitator". Ann N Y Acad Sci. 1988;539:5664.

214. Pachner AR. Lyme disease. Trends Neurosci. 1989 May;12(5):177-81.

215. Pachner AR, Duray P, Steere AC. Central nervous system manifestations of Lyme disease. Arch Neurol. 1989 Jul;46(7):790-5.

216. Pachner AR. Neurologic manifestations of Lyme disease, the new "great imitator". Rev Infect Dis. 1989 Sep-Oct;11 (Suppl 6):S1482-6.

217. Pachner AR, Braswell ST, Delaney E, Amemiya K, Major E. A rabbit model of Lyme neuroborreliosis: characterization by PCR, serology, and sequencing of the OspA gene from the brain. Neurology. 1994 Oct;44(10):1938-43.

218. Pachner AR. Early disseminated Lyme disease: Lyme meningitis. Am J Med. 1995; 98(4A):30S-37S .

219. Pachner AR, Steiner I. Lyme neuroborreliosis: infection, immunity and inflammation. Lancet Neurol 2007; 6:544- 52.

220. Paparone PW. Neuropsychiatric manifestations of Lyme disease. J Am Osteopath Assoc 1998 Jul;98(7):373-8

221. Pasareanu AR, Mygland Å, Kristensen Ø. A woman in her 50s with manic psychosis. Tidsskr Nor Laegeforen. 2012 Mar 6;132(5):537-9. 
222. Petrovic M, Vogelaers D, Van Renterghem L, De Reuck J, Afschrift M. Lyme borreliosis - A review of the late stages and treatment of four cases. Acta Clinica Belgica 1998;53-3:178-183.

223. Pfister HW, Preac-Mursic V, Wilske B, Rieder G, Forderreuther S, Schmidt S, Kapfhammer HP. Catatonic syndrome in acute severe encephalitis due to Borrelia burgdorferi infection. Neurology. 1993 Feb;43(2):433-5.

224. Plutchok JJ, Tikofsky RS, Liegner K, Kochevar JM, Fallon BA, Van Heertum RL. Tc-99m HMPAO Brain SPECT imaging in chronic Lyme disease. J Spiro Tick-borne Dis 1999; 6: 117-122.

225. Plutchok JJ, Tikofsky RS, Liegner KB, Fallon BA, Van Heertum RL. Brain SPECT imaging in chronic Lyme disease. J Spiro Tick-borne Dis. 1999; 6: 10-16.

226. Pollina DA, Elkins LE, Squires NK, Scheffer SR, Krupp LB. Does process-specific slowing account for cognitive deficits in Lyme disease? Appl Neuropsychol. 1999;6(1):27-32.

227. Pollina DA, Sliwinski M, Squires NK, Krupp LB. Cognitive processing speed in Lyme disease. Neuropsychiatry Neuropsychol Behav Neurol. 1999 Jan;12(1):72-8.

228. Poplawska R, Konarzewska B, Gudel-Trochimowicz I, Szulc A. Psychologic disorders in acute and persistent neuroborreliosis. Pol Merkuriusz Lek 2001 Jan;10(55):36-7

229. Poplawska R, Szulc A, Zajkowska J, Pancewicz S. Neuroborreliosis: a psychiatric problem? Psychiatr Pol 1999 MarApr;33(2):241-50.

230. Preac-Mursic V, Wilske B, Schierz G, Pfister HW, Einhäupl K. Repeated isolation of spirochetes from the cerebrospinal fluid of a patient with meningoradiculitis (Bannwarth syndrome). Eur J Clin Microbiol 1984; 3: 564-565.

231. Primavera A, Gazzola P, De Maria AF. Neuropsychological deficits in neuroborreliosis. Neurology. 1999 Sep $11 ; 53(4): 895-6$.

232. Puri BK, Shah M, Julu PO, Kingston MC, Monro JA. The association of lyme disease with loss of sexual libido and the role of urinary bladder detrusor dysfunction. Int Neurourol J. 2014 Jun; 18(2):95-7.

233. Quinn SJ, Boucher BJ, Booth JB. Reversible sensorineural hearing loss in Lyme disease. J Laryngol Otol. 1997 Jun;111(6):562-4.

234. Ragnaud JM, Morlat P, Buisson M, Ferrer X, Orgogozo JM, Julien J, Beylot J, Aubertin J. Neurologic manifestations of Lyme disease. Apropos of 25 cases. Rev Med Interne. 1995;16(7):487-94.

235. Ramanan SV. Loss of the sense of humor. Arch Intern Med 2000 Sep 11;160(16):2546 .

236. Ramesh G, Didier PJ, England JD, Santana-Gould L, Doyle-Meyers LA, Martin DS, et al. Inflammation in the pathogenesis of Lyme neuroborreliosis. Am J Pathol. 2015 May;185(5):1344-60.

237. Ramesh R, Borda JT, Dufor J, Kaushal D, Ramamoorthy R, Lackner AA, Philipp MT. Interaction of the Lyme disease spirochete Borrelia burgdorferi with brain parenchyma elicits inflammatory mediators from glial cells as well as glial and neuronal apoptosis. Am J Pathol. 2008; 173:1415-27 .

238. Ratnasamy N, Everett ED, Roland WE, McDonald G, Caldwell CW. Central nervous system manifestations of human ehrlichiosis. Clin Infect Dis 1996 Aug;23(2):314-9

239. Reddy KP, McCannon JB, Venna N. Diaphragm paralysis in Lyme disease: late occurrence in the course of treatment and long-term recovery. Ann Am Thorac Soc. 2015 Apr;12(4):618-20.

240. Reik L, Steere AC, Bartenhagen NH, Shope RE, Malawista SE. Neurologic abnormalities of Lyme disease. Medicine (Baltimore). 1979 Jul;58(4):281-94.

241. Rhee H, Cameron DJ. Lyme disease and pediatric autoimmune neuropsychiatric disorders associated with streptococcal infections (PANDAS): an overview. Int J Gen Med. 2012;5: 163-174.

242. Riedel M, Straube A, Schwarz MJ, Wilske B, Muller N. Lyme disease presenting as Tourette's syndrome. Lancet. 1998 Feb 7;351(9100):418-9

243. Roche Lanquetot R, Ader F, Durand MC, Carlier R, Defferriere H, Dinh A, Herrmann JL, Guillemot D, Perronne C, Salomon J. Results of a prospective standardized study of 30 patients with chronic neurological and cognitive disorders after tick bites. Med Mal Infect. 2008 Oct;38(10):543-8.

244. Roelcke U, Barnett W, Wilder-Smith E, Sigmund D, Hacke W. Untreated neuroborreliosis: Bannwarth's syndrome evolving into acute schizophrenia-like psychosis. A case report. J Neurol. 1992 Mar;239(3):129-31

245. Rudnik I, Konarzewska B, Zajkowska J, Juchnowicz D, Markowski T, Pancewicz SA The organic disorders in the course of Lyme disease. Pol Merkuriusz Lek. 2004 Apr;16(94):328-31

246. Rudnik I, Poplawska R, Zajkowska J, Konarzewska B, Juchnowicz D, Pancewicz SA. Mental problems in Lyme disease. Pol Merkuriusz Lek. 2003 Aug;15(86):161-4

247. Rudnik-Szalaj I, Poplawska R, Zajkowska J, Szulc A, Pancewicz SA, Gudel I.Mental disorders in Lyme disease. Pol Merkuriusz Lek. 2001 Nov;11(65):460-2.

248. Rundell JR, Wise MG. Neurosyphilis: a psychiatric perspective. Psychosomatics. 1985; 26: 287-295.

249. Samuel B, Axelband J, Mckim K, Leh D. Borrelia burgdorferi: A clinical chameleon. Consultant. 2015;55(7):530-535. 
250. Sanders K, Rogers JD. Lyme encephalopathy. Neurology. 1991 Jun;41(6):952-3.

251. Savely VR. Update on Lyme disease: the hidden epidemic. J Infus Nurs. 2008 Jul-Aug;31(4):236-40.

252. Schaller JL, Burkland GA, Langhoff PJ. Do Bartonella infections cause agitation, panic disorder, and treatmentresistant depression? MedGenMed. 2007 Sep 13;9(3):54.

253. Scerpella TA, Engber WD. Chronic Lyme disease arthritis: review of the literature and report of a case of wrist arthritis. J Hand Surg Am. 1992 May;17(3):571-5.

254. Scheffer RE, Linden S. Concurrent medical conditions with pediatric bipolar disorder. Curr Opin Psychiatry. 2007 Jul;20(4):398-401. Review.

255. Schneider RK, Robinson MJ, Levenson JL. Psychiatric presentations of non-HIV infectious diseases. Psychiatr Clin North Am 2002 Mar;25(1):1-16

256. Schoof J, Kluge C, Heinze HJ, Galazky I.Startle myoclonus induced by Lyme neuroborreliosis: a case report. J Med Case Rep 2013(May); 7(1): 124. DOI: 10.1186/1752-1947-7-124

257. Schuler PA. Gifted Students and Lyme Disease: What Educators, Counselors, and Parents Need to Know. Gifted Child Today 2013 36: 35. DOI: 10.1177/1076217512465288

258. Shadick NA, Phillips CB, Logigian EL, Steere AC, Kaplan RF, Berardi VP, Duray PH, Larson MG, Wright EA, Ginsburg KS, Katz JN, Liang MH. The long-term clinical outcomes of Lyme disease. A population-based retrospective cohort study. Ann Intern Med. 1994 Oct 15;121(8):560-7.

259. Shamim A, Shamim S; Liss G; Nylen E; Pincus J; Yepes M. Constipation Heralding Neuroborreliosis Arch Neurol. 2005;62:671-673.

260. Sherr VT. Human babesiosis--an unrecorded reality. Med Hypotheses. 2004;63(4):609-15

261. Sherr VT. Munchausen's syndrome by proxy and Lyme disease: medical misogyny or diagnostic mystery? Med Hypotheses. 2005;65(3):440-7.

262. Sherr VT. Panic attacks may reveal previously unsuspected chronic disseminated Lyme disease. J Psychiatr Pract. 2000 Nov;6(6):352-6.

263. Shotland LI, Mastrioanni MA, Choo DL, Szymko-Bennett YM, Dally LG, Pikus AT, Sledjeski K, Marques A. Audiologic manifestations of patients with post-treatment Lyme disease syndrome. Ear Hear. 2003 Dec;24(6):50817

264. Smith AJ, Oertle J, Prato D. Borrelia burgdorferi: Cell biology and clinical manifestations in latent chronic Lyme. Open J Med Microbiol. 2014;4:210-223.

265. Smith IS, Rechlin DP. Delayed diagnosis of neuroborreliosis presenting as bell palsy and meningitis. J Am Osteopath Assoc. 2010 Aug;110(8):441-4.

266. Smith V, Traquina DN. Pediatric bilateral facial paralysis. Laryngoscope. 1998 Apr;108(4 Pt 1):519-23.

267. Sno HN. Signs and significance of a tick-bite: psychiatric disorders associated with Lyme disease. Tijdschr Psychiatr. 2012;54(3):235-43.

268. Sparsa L, Blanc F, Lauer V, Cretin B, Marescaux C, Wolff V. Recurrent ischemic strokes revealing Lyme meningovasculitis. Rev Neurol (Paris). 2009 Mar;165(3):273-7.

269. Steere AC, Pachner AR, Malawista SE. Neurologic abnormalities of Lyme disease: successful treatment with highdose intravenous penicillin. Ann Intern Med. 1983 Dec;99(6):767-72.

270. Steere AC. A 58-year-old man with a diagnosis of chronic Lyme disease, 1 year later. JAMA. 2002 Aug 28;288(8):1002- 10 .

271. Stein SL, Solvason HB, Biggart E, Spiegel D. A 25-year-old woman with hallucinations, hypersexuality, nightmares, and a rash. Am J Psychiatry. 1996 Apr;153(4):545-51.

272. Steinberg SH, Strickland GT, Pena C, Israel E. Lyme disease surveillance in Maryland, 1992. Ann Epidemiol. 1996 Jan;6(1):24-9.

273. Stratmoen M.Neurological complications of Lyme disease: Dilemmas in Diagnosis and Treatment. Neurology Today 2004;4(4)71-5.

274. Stricker RB, Winger EE. Holmes-Adie syndrome and Lyme disease. Lancet. 2001 Mar 10;357(9258):805.

275. Stricker RB, Winger EE. Musical hallucinations in patients with Lyme disease. South Med J 2003; 96(7):711- 715.

276. Stricker RB, Green CL, Savely VR, Chamallas SN, Johnson L. Safety of intravenous antibiotic therapy in patients referred for treatment of neurologic Lyme disease. Minerva Med. 2010 Feb;101(1):1-7.

277. Stricker RB, DeLong AK, Green CL, Savely VR, Chamallas SN, Johnson L. Benefit of intravenous antibiotic therapy in patients referred for treatment of neurologic Lyme disease. Int J Gen Med 2011; 4: 639-646.

278. Stricker RB, Johnson L. Anti-neural antibody reactivity in patients with a history of Lyme borreliosis and persistent symptoms. Brain Behavior Immun. 2010;24: 1025. 
279. Sumiya H, Kobayashi K, Mizukoshi C, Aoki T, Koshino Y, Taki J, Tonami N. Brain perfusion SPECT in Lyme neuroborreliosis. J Nucl Med. 1997 Jul;38(7):1120-2.

280. Svetina C, Barr WB, Rastogi R, Hilton E. The neuropsychological examination of naming in Lyme borreliosis. Appl Neuropsychol. 1999;6(1):33-8.

281. Tager FA, Fallon BA, Keilp J, Rissenberg M, Jones CR, Liebowitz MR. A controlled study of cognitive deficits in children with chronic Lyme disease. J Neuropsychiatr Clin Neurosci 2001;13:500-507.

282. Tager FA, Fallon BA. Psychiatric and cognitive features of Lyme disease. Psychiatr Ann 2001; 31: 173-181.

283. Treib J, Grauer MT, Haass A, Langenbach J, Holzer G, Woessner R. Chronic fatigue syndrome in patients with Lyme borreliosis. Eur Neurol. 2000;43(2):107-9.

284. Tselis A, MD, Booss J. Behavioral consequences of infections of the central nervous system: with emphasis on viral infections. J Am Acad Psychiatry Law 2003;31:289-98.

285. Vamos E, Pardutz A, Klivenyi P, Toldi J, Vecsei L The role of kynurenines in disorders of the central nervous system: Possibilities for neuroprotection. J Neurol Sci. 2009 Mar 4.

286. van den Bergen HA, Smith JP, van der Zwan A. Lyme Psychosis. Ned Tijdschr Geneeskd 1993 Oct 9;137(41):2098-100.

287. Vázquez M, Sparrow SS, and Shapiro ED. Long-term neuropsychologic and health outcomes of children with facial nerve palsy attributable to Lyme disease. Pediatrics 2003; 112(2): e93-e97.

288. Vital C, Vital A, Lagueny A, Larribau E, Saintarailles J, Julien J. Subacute inflammatory polyneuropathy: two cases with plasmacytoid histiocytes in the endoneurium. Ultrastruct Pathol. 1998 Sep-Oct;22(5):377-83.

289. Volkman D Anti-neural antibody reactivity in patients with a history of Lyme borreliosis and persistent symptoms. Brain Behavior Immun. 2010;24:1026.

290. Waniek C, Prohovnik I, Kaufman MA, Dwork AJ.Rapidly progressive frontal-type dementia associated with Lyme disease. J Neuropsychiatry Clin Neurosci 1995;7(3):345-7.

291. Weder B, Wiedersheim P, Matter L, Steck A, Otto F. Chronic progressive neurological involvement in Borrelia burgdorferi infection. J Neurology 1987;234:40-43.

292. Weissenbacher S, Ring J, Hofmann H. Gabapentin for the symptomatic treatment of chronic neuropathic pain in patients with late-stage Lyme borreliosis: a pilot study. Dermatology. 2005;211(2):123-7.

293. Westervel HJ, McCaffrey RJ. Neuropsychological functioning in chronic Lyme disease. Neuropsychol Rev 2002 Sep;12(3):153-77 Review.

294. Wilke M, Eiffert H, Christen HJ, Hanefeld F. Primarily chronic and cerebrovascular course of Lyme neuroborreliosis: case reports and literature review. Arch Dis Child. 2000 Jul;83(1):67-71. Review.

295. Wittwer B, Pelletier S, Ducrocq X, Maillard L, Mione G, Richard S. Cerebrovascular events in Lyme neuroborreliosis. J Stroke Cerebrovasc Dis. 2015 Jul;24(7):1671-8.

296. Woessner R, Treib J. Pain, fatigue, depression after borreliosis. Antibiotics used up--what next? MMW Fortschr Med. 2003 Sep 18;145(38):45-8.

297. Wokke JHJ, van Gijn J, Elderson A, Stanek G. Chronic forms of Borrelia burgdorferi infection of the nervous system. Neurology 1987;37:1031-1034.

298. Yolken RH, Torrey EF. Are some cases of psychosis caused by microbial agents? A review of the evidence. Mol Psychiatry. 2008 May;13(5):470-9.

299. Younger DS, Rosoklija G, Hays AP. Persistent painful Lyme radiculoneuritis. Muscle Nerve. 1995 Mar;18(3):359-60.

300. Zajkowska JM, Hermanowska-Szpakowicz T, Kondrusik M, Pancewicz SA. Neurologic syndromes in Lyme disease. Pol Merkuriusz Lek. 2000 Aug;9(50):584-8. Review.

301. Zajkowska JM, Poplawska R, Pancewicz SA, Kondrusik M, Gudel I, Snarska I. Mental disorders in the course of neuroborreliosis: own observation. Psychiatr Pol 1999 Nov-Dec;33(6):939-46.

302. Zamponi N, Cardinali C, Tavoni MA, Porfiri L, Rossi R, Manca A. Chronic neuroborreliosis in infancy. Ital J Neurol Sci. 1999; 20:303-307.

303. Zhang Y, Lafontant G, Bonner FJ Jr. Lyme neuroborreliosis mimics stroke: a case report. Arch Phys Med Rehabil. 2000 Apr;81(4):519-21.

\section{Dementia and Lyme/Tickborne Diseases}

1. Aboul-Enein F, Kristoferitsch W. Normal pressure hydrocephalus or neuroborreliosis? Wien Med Wochenschr. 2009;159(1-2):58-61. 
2. Almeida OP, Lautenschlager NT. Dementia associated with infectious diseases. Int Psychogeriatr. 2005;17 (Suppl 1):S65- 77.

3. Blanc F, Philippi N, Cretin B, Kleitz C, Berly L, Jung B, Kremer S, Namer IJ, Sellal F, Jaulhac B, de Seze J. Lyme neuroborreliosis and dementia. J Alzheimers Dis. 2014; 41(4): 1087-93.

4. Duyckaerts C, Delatour B, Potier MC. Classification and basic pathology of Alzheimer disease. Acta Neuropathol 2009;118: 5-36

5. Galbussera A, Tremolizzo L, Isella V, Gelosa G, Vezzo R, Vigorè L, et al. Lack of evidence for Borrelia burgdorferi seropositivity in Alzheimer disease. Alzheimer Dis Assoc Disord 2008;22: 308.

6. Guo JP, Arai T, Miklossy J, McGeer PL. A $\beta$ and tau form soluble complexes that may promote self aggregation of both into the insoluble forms observed in Alzheimer's disease. Proc Natl Acad Sci U S A. 2006 Feb 7;103:1953-8.

7. Haass C, Selkoe DJ. Soluble protein oligomers in neurodegeneration: lessons from the Alzheimer's amyloid betapeptide. Nat Rev Mol Cell Biol 2007;8: 101-12.

8. Hardy J, Selkoe DJ. The amyloid hypothesis of Alzheimer's disease: progress and problems on the road to therapeutics. Science 2002;297: 353-6

9. Holmes C, Cotterell D. Role of infection in the pathogenesis of Alzheimer's disease: implications for treatment. CNS Drugs 2009;23(12): 993-1002.

10. Honjo K, van Reekum R, Verhoeff NP. Alzheimer's disease and infection: Do infectious agents contribute to progression of Alzheimer's disease? Alzheimers Dement. 2009;5: 348-360 .

11. Itzhaki RF, Lathe R, Balin BJ, Ball MJ, Bearer EL, Braak H, Bullido MJ, Carter C, Clerici M, Cosby SL, Del Tredici K, Field H, Fulop T, Grassi C, Griffin WS, Haas J, Hudson AP, Kamer AR, Kell DB, Licastro F, Letenneur L, Lövheim H, Mancuso R, Miklossy J, Otth C, Palamara AT, Perry G, Preston C, Pretorius E, Strandberg T, Tabet $\mathrm{N}$, Taylor-Robinson SD, Whittum-Hudson JA. Microbes and Alzheimer's Disease. J Alzheimers Dis. 2016;51(4):979-84.

12. Jack CR Jr, Knopman DS, Jagust WJ, Shaw LM, Aisen PS, Weiner MW, Petersen RC, Trojanowski JQ. Hypothetical model of dynamic biomarkers of the Alzheimer's pathological cascade. Lancet Neurol 2010;9:119-28.

13. Khan UA, Liu L, Provenzano FA, Berman DE, Profaci CP, Sloan R, Mayeux R, Duff KE, Small SA. Molecular drivers and cortical spread of lateral entorhinal cortex dysfunction in preclinical Alzheimer's disease. Nat Neurosci. 2014 Feb;17(2):304-11.

14. Lue LF, Kuo YM, Roher AE, Brachova L, Shen Y, Sue L, Beach T, Kurth JH, Rydel RE, Rogers J. Soluble amyloid beta peptide concentration as a predictor of synaptic change in Alzheimer's disease. Am J Pathol 1999; $155:$ : 853-862

15. MacDonald AB. Concurrent neocortical Borreliosis and Alzheimer's disease: Demonstration of a spirochetal cyst form. Ann NY Acad Sci 1988;539:468-470.

16. MacDonald AB, Berger BW, Schwan TG. Clinical implications of delayed growth of the Lyme disease spirochete, Borrelia burgdorferi. Acta Trop 1990 48; (2): 89-94.

17. MacDonad AB. In situ DNA hybridization study of granulovacuolar degeneration in human Alzheimer autopsy neurons for flagellin b transcriptomes of Borrelia burgdorferi. Alzheimer's Dis Dementia 2006; 2 (Suppl. 1): S207.

18. MacDonald AB. Cystic borrelia in Alzheimer's disease and in non-dementia neuroborreliosis. Alzheimer's Dementia 2006; 2 (Suppl. 1):S433.

19. MacDonald AB. Plaques of Alzheimer's disease originate from cysts of Borrelia burgdorferi, the Lyme disease spirochete. Med Hypotheses. 2006;67(3):592-600.

20. MacDonald AB. Spirochetal cyst forms in neurodegenerative disorders...hiding in plain sight. Med Hypotheses. 2006;67(4):819-32. Epub 2006 Jul 7.

21. MacDonald AB. Transfection "Junk" DNA - a link to the pathogenesis of Alzheimer's disease? Med Hypotheses. 2006;66(6):1140-1.

22. MacDonald AB. Alzheimer's neuroborreliosis with trans-synaptic spread of infection and neurofibrillary tangles derived from intraneuronal spirochetes. Med Hypotheses 2007; 68: 822-825. [7 of 10 cases of Alzheimer's disease had B. burgdorferi in their brains].

23. MacDonald AB. Alzheimer's disease Braak Stage progressions reexamined and redefined as Borrelia infection transmission through neural circuits. Med Hypotheses. 2007; 68(5): 1059-64

24. MacDonald AB, Miranda JM. Concurrent neocortical borreliosis and Alzheimer's disease. Hum Pathol. 1987 Jul;18(7):759-61.

25. MacDonald AB. Borrelia in the brains of patients dying with dementia. JAMA. 1986;256:2195-2196. 
26. MacDonald AB. Concurrent neocortical borreliosis and Alzheimer's disease: Demonstration of a spirochetal cyst form. Ann N Y Acad Sci 1988; 539:468-470.

27. McLaughlin R, Kin NM, Chen MF, Nair NP, Chan EC. Alzheimer's disease may not be a spirochetosis. Neuroreport 1999;10(7), 1489-91.

28. Meer-Scherrer L, Chang Loa C, Adelson ME, Mordechai E, Lobrinus JA, Fallon BA, Tilton RC. Lyme disease associated with Alzheimer's disease. Curr Microbiol. 2006 Apr;52(4):330-2.

29. Miklossy J. Alzheimer's disease — a spirochetosis? NeuroReport 1993; 4: 841-848.

30. Miklossy J, Gern L, Darekar P, Janzer RC, Loos H. Senile plaques, neurofibrillary tangles and neuropil threads contain DNA? J Spiro Tick-borne Dis 1995; 2: 1-5.

31. Miklossy JM, Khalili K, Gern L, Ericson RL, Darekar P, Bolle L, Hurlimann J, and Paster BJ. Borrelia burgdorferi persists in the brain in chronic Lyme neuroborreliosis and may be associated with Alzheimer's disease. J Alzheimers Dis 2004; 6; 639-649.

32. Miklossy J, Kasas S, Zurn AD, McCall S, Yu S, and McGeer PL. Persisting atypical and cystic forms of Borrelia burgdorferi and local inflammation in Lyme neuroborreliosis. J Neuroinflammation 2008; 5: 40-57.

33. Miklossy J. Chronic or late Lyme neuroborreliosis: analysis of evidence compared to chronic or late neurosyphilis. Open Neurol J 2012;6: 146-157.

34. Miklossy J. Chronic inflammation and amyloidogenesis in Alzheimer's disease -- role of spirochetes. Alzheimers Dis. 2008 May;13(4):381-91. Review.

35. Miklossy J. Alzheimer's disease - a neurospirochetosis. Analysis of the evidence following Koch's and Hill's criteria. J Neuroinflammation. 2011 Aug 4;8(1):90.

36. Miklossy J. Historic evidence to support a causal relationship between spirochetal infections and Alzheimer's disease. Frontiers Aging Neurosci. 2015 Apr 16;7:46.

37. Miklossy J. Bacterial amyloid and DNA are important constituents of senile plaques: Further evidence of the spirochetal and biofilm nature of senile plaques. J Alzheimer's Dis. 2016;53:1459-1473.

38. Miklossy J. Emerging roles of pathogens in Alzheimer disease. Expert Rev Mol Med. 2011 Sep 20;13:e30.

39. Miklossy J, Donta SE, Mueller K, Nolte O, Perry G. Chronic or late Lyme neuroborreliosis: present and future. Open Neurol J. 2012;6:78.

40. Miklossy J, Kasas S, Janzer RC, Ardizzoni F, Van der Loos H. Further ultrastructural evidence that spirochaetes may play a role in the aetiology of Alzheimer's disease. Neuroreport. 1994 Jun 2;5(10):1201-4.

41. Miklossy J, Kasas S, Zurn AD, McCall S, Yu S, McGeer PL. Persisting atypical and cystic forms of Borrelia burgdorferi and local inflammation in Lyme neuroborreliosis. J. Neuroinflammation. 2008;5: 40.

42. Miklossy J, Khalili K, Gern L, Ericson RL, Darekar P, Bolle L, Hurlimann J, Paster BJ. Borrelia burgdorferi persists in the brain in chronic Lyme neuroborreliosis and may be associated with Alzheimer disease. J Alzheimer's Dissease 2004;6 (6): 639-49; discussion 673-681.

43. Miklossy J, Kris A, Radenovic A, Miller L, Forro L, Martins R, Reiss K, Darbinian N, Darekar P, Mihaly L, Khalili K. Beta-amyloid deposition and Alzheimer's type changes induced by Borrelia spirochetes. Neurobiol Aging. 2006 Feb;27(2):228-36.

44. Miklossy J, Kuntzer T, Bogousslavsky J, Regli F, Janzer RC. Meningovascular form of neuroborreliosis: Similarities between neuropathological findings in a case of Lyme disease and those occurring in tertiary neurosyphilis. Acta Neuropathol 1990;80: 568-572.

45. Miklossy J, Taddei K, Martins R, Escher G, Kraftsik R, Pillevuit O, et al. Alzheimer disease: curly fibers and tangles in organs other than brain. J Neuropathol Exp Neurol. 1999;58: 803-814.

46. Miklossy J, Van der Loos H. The long distance effects of brain lesions: A study of myelinated pathways in the human brain using polarizing and fluorescence microscopy. J Neuropathol Exp Neurol 1991;50: 1-15.

47. Miklossy J. Chronic or late lyme neuroborreliosis: analysis of evidence compared to chronic or late neurosyphilis. Open Neurol J. 2012;6: 146-57.

48. Miklossy J. Alzheimer's disease - a neurospirochetosis. Analysis of the evidence following Koch's and Hill's criteria. J Neuroinflammation. 2011;8(1):90.

49. Miklossy J. Biology and neuropathology of dementia in syphilis and Lyme disease. Handb Clin Neurol. 2008;89:825-44.

50. Miklossy J. The lack of correlation between the incidence of Lyme disease and deaths due to Alzheimer's disease cannot reflect the lack of involvement of Borrelia burgdorferi in Alzheimer's dementia. J Alzheimers Dis 2014;42:115-118. 
51. Nilsson P, Loganathan K, Sekiguchi M, Matsuba Y, Hui K, Tsubuki S, et al. A $\beta$ secretion and plaque formation depend on autophagy. Cell Reports 2013;5: 61-69.

52. Pappolla MA, Omar R, Saran B, Andorn A, Suarez M, Pavia C, et al. Concurrent neuroborreliosis and Alzheimer's disease: analysis of the evidence. Hum Pathol 1989;20: 753-7.

53. Riek R. Infectious Alzheimer's disease? Nature 2006;444: 429-431.

54. Ruitenberg A, den Heijer T, Bakker SL, van Swieten JC, Koudstaal PJ, Hofman A, Breteler MM. Cerebral hypoperfusion and clinical onset of dementia: the Rotterdam study. Ann Neurol. 2005;57: 789-94.

55. Selkoe DJ. Preventing Alzheimer's disease. Science 2012;337: 1488-92.

56. Suter O-C, Sunthorn T, Kraftsik R, Straubel J, Darekar P, Khalili K, Miklossy J. Cerebral Hypoperfusion generates cortical watershed microinfarcts in Alzheimer disease. Stroke 2002;33: 1986-1992 .

57. Verdile G, Gnjec A, Miklossy J, Fonte J, Veurink G, Bates K, Kakulas B, Mehta PD, Milward EA, Tan N, Lareu R, Lim D, Dharmarajan A, Martins RN. Protein markers for Alzheimer disease in the frontal cortex and cerebellum. Neurology. 2004 Oct 26;63(8):1385-92.

58. Waniek C, Prohovnik I, Kaufman MA, Dwork AJ. Rapidly progressive frontal-type dementia associated with Lyme disease. J Neuropsych Clin Neurosci. 1995;7(3):345-7.

59. Williams WM, Torres S, Siedlak SL, Castellani RJ, Perry G, Smith MA, Zhu X. Antimicrobial peptide betadefensin-1 expression is upregulated in Alzheimer's brain. J Neuroinflammation. 2013;10(1): 127.

60. Zlokovic BV. Neurovascular pathways to neurodegeneration in Alzheimer's disease and other disorders. Nat Rev Neurosci 2011;12, 723-38.

\section{Congenital/Sexual Transmission of Lyme/Tickborne Diseases}

1. Alekseev AN, Dubinina HV. Exchange of Borrelia burgdorferi between Ixodes persulcatus (Ixodidae: Acarina) sexual partners. J Med Entomol. 1996;33(3):351-354.

2. Alexander JM, Cox SM. Lyme disease and pregnancy. Infect Dis Obstet Gynecol. 1995;3(6):256-61.

3. Burgess EC, Amundson TE, Davis JP, Kaslow RA, Edelman R. Experimental inoculation of Peromyscus spp. with Borrelia burgdorferi: evidence of contact transmission. Am J Trop Med Hyg. 1986; 35: 355-9.

4. Carlomagno G, Luksa V, Candussi G, Rizzi GM, Trevisan G. Lyme Borrelia positive serology associated with spontaneous abortion in an endemic Italian area. Acta Eur Fertil 1988;19(5), 279-81.

5. Cornett JK, Malhotra A, Hart D. Vertical transmission of babesiosis from a pregnant, splenectomized mother to her neonate. Infect Dis Clin Pract 2012; 20: 408-411.

6. Dhand A, Nadelman RB, Aguero-Rosenfeld M, Haddad FA, Stokes DP, Horowitz HW. Human granulocytic anaplasmosis during pregnancy: case series and literature review. Clin Infect Dis. 2007 Sep 1;45(5):589-93.

7. Elliott DJ, Eppes SC, Klein JD. Teratogen update: Lyme disease. Teratology 2001;64:276-281.

8. Gabitzsch ES, Piesman J, Dolan MC, Sykes CM, Zeidner NS. Transfer of Borrelia burgdorferi s.s. infection via blood transfusion in a murine model. J Parasitol. 2006 Aug;92(4):869-70.

9. Gardner T. Lyme disease. In JS Remington and JO Klein (eds.), Infectious Diseases of the Fetus and New Born Infant. WB Saunders Co., Philadelphia, PA. 2001, pp. 519-641.

10. Mahram M, Ghavami MB. Congenital tick-borne relapsing fever: report of a case with transplacental transmission in the Islamic Republic of Iran. East Mediterr Health J. 2009 May-Jun;15(3):761-4.

11. Harvey WT, Salvato P. 'Lyme disease': ancient engine of an unrecognized borreliosis pandemic? Med Hypotheses. 2003;60(5):742-59.

12. Hercogova J, Vanousova D. Syphilis and borreliosis during pregnancy. Dermatol Ther 2008;21(3), 205-9.

13. Jasik KP, Okła H, Słodki J, Rozwadowska B, Słodki A, Rupik W. Congenital tick-borne diseases: Is this an alternative route of transmission of tick-borne pathogens in mammals? Vector Borne Zoonotic Dis. 2015 Nov;15(11):637-44.

14. Krause PJ, Vannier E. Transplacental transmission of human babesiosis. Infect Dis Clin Pract 2012; 20: $365-367$.

15. Kumi-Diaka J, Harris O. Viability of Borrelia burgdorferi in stored semen. Br Vet J. 1995 Mar-Apr;151(2):221-4.

16. Lakos A, Solymosi N. Maternal Lyme borreliosis and pregnancy outcome. Int J Infect Dis 2010;14(6): e494-8.

17. Larsson C, Andersson M, Guo BP, Nordstrand A, Hagerstrand I, Carlsson S, Bergstrom S. Complications of pregnancy and transplacental transmission of relapsing-fever borreliosis. J Infect Dis. 2006 Nov 15;194(10):1367-74.

18. Lavoie PE, Lattner BP, Duray PH, Barbour AG, Johnson HC. Culture positive seronegative transplacental Lyme borreliosis infant mortality. Arthritis Rheum. 1987; 30 No 4, 3(Suppl):S50. 
19. MacDonald AB. Gestational Lyme borreliosis. Implications for the fetus. Rheum Dis Clin North Am. 1989 Nov;15(4):657-77.

20. MacDonald AB. Human fetal borreliosis, toxemia of pregnancy, and fetal death. Zentralbl Bakteriol Mikrobiol Hyg A. 1986 Dec;263(1- 2):189-200.

21. MacDonald AB, Benach JL, Burgdorfer W. Stillbirth following maternal Lyme disease. N Y State J Med. 1987 Nov;87(11):615-6.

22. Maraspin V, Cimperman J, Lotric-Furlan S, Pleterski-Rigler D, Strle F. Treatment of erythema migrans in pregnancy. Clin Infect Dis. 1996 May;22(5):788-93.

23. Markowitz LE, Steere AC, Benach JL, Slade JD, Broome CV. Lyme disease during pregnancy. JAMA.1986; 255(24): 3394-6.

24. Mikkelsen AL, Palle C. Lyme disease during pregnancy. Acta Obstet Gynecol Scand 1987;66(5): 477-8.

25. Mylonas I. Borreliosis during pregnancy: A risk for the unborn child? Vector Borne Zoonotic Dis. 2011;11:891-8.

26. Nadal D, Hunziker UA, Bucher HU, Hitzig WH, Duc G. Infants born to mothers with antibodies against Borrelia burgdorferi at delivery. Eur J Pediatr 1989;148(5): 426-7.

27. Onk G, Acun C, Kalayci M, Cagavi F. Gestational Lyme disease as a rare cause of congenital hydrocephalus. J Turkish German Gyn Assoc Artemis. 2005; 6(2): 156-157.

28. Schlesinger PA, Duray PH, Burke BA, Steere AC, Stillman MT. Maternal-fetal transmission of the Lyme disease spirochete, Borrelia burgdorferi. Ann Intern Med. 1985;103: 67-8.

29. Schutzer SE, Janniger CK, Schwartz RA. Lyme disease during pregnancy. Cutis 1991;47(4): 267-8.

30. Sethi S, Alcid D, Kesarwala H, Tolan RW Jr. Probable congenital babesiosis in infant, New Jersey, USA. Emerg Infect Dis. 2009 May;15(5):788-91.

31. Silver H. Lyme disease during pregnancy. Infect Dis Clin North Am. 1997;11(1):93-97.

32. Silver RM, Yang L, Daynes RA, Branch DW, Salafia CM, Weis JJ. Fetal outcome in murine Lyme disease. Infect Immun. 1995 Jan;63(1):66-72.

33. Stricker RB, Middelveen MJ. Sexual transmission of Lyme disease: challenging the tickborne disease paradigm. Expert Rev Anti-Infect Ther. 2015;13:1303-1306.

34. Stricker RB, Moore DH, Winger EE. Clinical and immunologic evidence of transmission of Lyme disease through intimate human contact. J Invest Med. 2004;52: S15

35. Strobino BA, Williams CL, Abid S, Chalson R, Spierling P. Lyme disease and pregnancy outcome: a prospective study of two thousand prenatal patients. Am J Obstet Gynecol. 1993; 169(2 Pt 1): 367-74.

36. van Holten J, Tiems J, Jongen VH. Neonatal Borrelia duttoni infection: a report of three cases. Trop Doct 1997;27(2): 115-6.

37. Weber K, Bratzke HJ, Neubert U, Wilske B, Duray PH. Borrelia burgdorferi in a newborn despite oral penicillin for Lyme borreliosis during pregnancy. Pediatr Infect Dis J. 1988; 7:286-9.

38. Williams CL, Strobino B, Weinstein A, Spierling P, Medici F. Maternal Lyme disease and congenital malformations: a cord blood serosurvey in endemic and control areas. Paediatr Perinat Epidemiol 1995;9(3): 320-30.

39. Yagupsky P, Moses S. Neonatal Borrelia species infection (relapsing fever). Am J Dis Child. 1985 Jan;139(1):74-6.

SOURCE: ILADS website, http://www.ilads.org/ilads_news/2017/list-of-700-articles-citing-chronic-infectionassociated-with-tick-borne-disease-compiled-by-dr-robert-bransfield/

\section{Appendix B}

\section{Studies Used for Identification of Symptoms and Signs in CLD*}

\section{CLD-U}

1. Berger TG, Schoerner C, Schell H, Simon M, Schuler G, Röllinghoff M, Gessner A. Two unusual cases of diffuse acrodermatitis chronica atrophicans seronegative for Lyme borreliosis. Eur J Clin Microbiol Infect Dis. 2003 Jun;22(6):392-5.

2. Bergler-Klein J, Ullrich R, Glogar D, Stanek G. Lyme borreliosis and cardiomyopathy. Wien Med Wochenschr. 1995;145(7-8):196-8.

3. Cimmino MA, Azzolini A, Tobia F, Pesce CM. Spirochetes in the spleen of a patient with chronic Lyme disease. Am J Clin Pathol. 1989 Jan;91(1):95-7. 
4. Cimmino MA, Accardo S. Long term treatment of chronic Lyme arthritis with benzathine penicillin. Ann Rheum Dis. 1992 Aug;51(8):1007-8.

5. Coyle PK, Schutzer SE, Deng Z, Krupp LB, Belman AL, Benach JL, Luft BJ. Detection of Borrelia burgdorferispecific antigen in antibody-negative cerebrospinal fluid in neurologic Lyme disease. Neurology. 1995 Nov;45(11):2010-5.

6. Karma A, Pirttilä TA, Viljanen MK, Lähde YE, Raitta CM. Secondary retinitis pigmentosa and cerebral demyelination in Lyme borreliosis. Br J Ophthalmol. 1993 Feb;77(2):120-2.

7. Lawrence C, Lipton RB, Lowy FD, Coyle PK. Seronegative chronic relapsing neuroborreliosis. Eur Neurol. 1995;35(2):113-7.

8. Leslie TA, Levell NJ, Cutler SJ, Cann KJ, Smith ME, Wright DJ, Gilkes JJ, Robinson TW. Acrodermatitis chronica atrophicans: a case report and review of the literature. Br J Dermatol. 1994 Nov;131(5):687-93.

9. Levy E, Morruzzi C, Barbarini A, Sordet C, Cribier B, Jaulhac B, Lipsker D. Clinical images: toe dactylitis revealing late Lyme borreliosis. Arthritis Rheum. 2012 Apr;64(4):1293.

10. Mikkilä HO, Seppälä IJ, Viljanen MK, Peltomaa MP, Karma A. The expanding clinical spectrum of ocular Lyme borreliosis. Ophthalmology. 2000 Mar;107(3):581-7.

11. Murillo G, Ramírez B, Romo LA, Muñoz-Sanz A, Hileeto D, Calonge M. Oculopalpebral borreliosis as an unusual manifestation of Lyme disease. Cornea. 2013 Jan;32(1):87-90.

12. Nocton JJ, Dressler F, Rutledge BJ, Rys PN, Persing DH, Steere AC. Detection of Borrelia burgdorferi DNA by polymerase chain reaction in synovial fluid from patients with Lyme arthritis. N Eng J Med 1994; 330: $229-234$.

13. Nocton JJ, Bloom BJ, Rutledge BJ, Persing DH, Logigian EL, Schmid CH, Steere AC. Detection of Borrelia burgdorferi DNA by polymerase chain reaction in cerebrospinal fluid in Lyme neuroborreliosis. J Infect Dis. 1996 Sep;174(3):623-7.

14. Oksi J, Voipio-Pulkki LM, Uksila J, Pulkki K, Laippala P, Viljanen MK. Borrelia burgdorferi infection in patients with suspected acute myocardial infarction. Lancet. 1997 Nov 15;350:1447-8.

15. Preac-Mursic V, Pfister HW, Spiegel H, Burk R, Wilske B, Reinhardt S, Böhmer R. First isolation of Borrelia burgdorferi from an iris biopsy. J Clin Neuroophthalmol. 1993 Sep;13(3):155-61; discussion 162.

16. Snydman DR, Schenkein DP, Berardi VP, Lastavica CC, Pariser KM. Borrelia burgdorferi in joint fluid in chronic Lyme arthritis. Ann Intern Med. 1986 Jun;104(6):798-800.

\section{CLD-T}

1. Battafarano DF, Combs JA, Enzenauer RJ, Fitzpatrick JE. Chronic septic arthritis caused by Borrelia burgdorferi. Clin Orthop Relat Res. 1993 Dec;(297):238-41.

2. Coyle PK, Schutzer SE, Deng Z, Krupp LB, Belman AL, Benach JL, Luft BJ. Detection of Borrelia burgdorferispecific antigen in antibody-negative cerebrospinal fluid in neurologic Lyme disease. Neurology. 1995 Nov;45(11):2010-5.

3. Frey M, Jaulhac B, Piemont Y, Marcellin L, Boohs PM, Vautravers P, Jesel M, Kuntz JL, Monteil H, Sibilia J. Detection of Borrelia burgdorferi DNA in muscle of patients with chronic myalgia related to Lyme disease. Am J Med. 1998 Jun;104(6):591-4.

4. Häupl T, Hahn G, Rittig M, Krause A, Schoerner C, Schönherr U, Kalden JR, Burmester GR. Persistence of Borrelia burgdorferi in ligamentous tissue from a patient with chronic Lyme borreliosis. Arthritis Rheum. 1993 Nov;36(11):1621-6.

5. Hudson BJ, Stewart M, Lennox VA, Fukunaga M, Yabuki M, Macorison H, Kitchener-Smith J. Culture-positive Lyme borreliosis. Med J Aust. 1998 May 18;168(10):500-2.

6. Lawrence C, Lipton RB, Lowy FD, Coyle PK. Seronegative chronic relapsing neuroborreliosis. Eur Neurol. 1995;35(2):113-7.

7. Liegner KB, Shapiro JR, Ramsay D, Halperin AJ, Hogrefe W, Kong L. Recurrent erythema migrans despite extended antibiotic treatment with minocycline in a patient with persisting Borrelia burgdorferi infection. $\mathrm{J}$ Am Acad Dermatol 1993; 28: 312-314.

8. Mikkilä HO, Seppälä IJ, Viljanen MK, Peltomaa MP, Karma A. The expanding clinical spectrum of ocular Lyme borreliosis. Ophthalmology. 2000 Mar;107(3):581-7.

9. Nocton JJ, Dressler F, Rutledge BJ, Rys PN, Persing DH, Steere AC. Detection of Borrelia burgdorferi DNA by polymerase chain reaction in synovial fluid from patients with Lyme arthritis. N Engl J Med. 1994 Jan 27;330(4):229-34. 
10. Preac-Mursic V, Weber K, Pfister HW, Wilske B, Gross B, Baumann A, Prokop J. Survival of Borrelia burgdorferi in antibiotically treated patients with Lyme borreliosis. Infection. 1989 Nov-Dec;17(6):355-9.

11. Preac-Mursic V, Pfister HW, Spiegel H, Burk R, Wilske B, Reinhardt S, Böhmer R. First isolation of Borrelia burgdorferi from an iris biopsy. J Clin Neuroophthalmol. 1993 Sep;13(3):155-61; discussion 162.

12. Trevisan G, Cinco M, Agolzer A. Roseolar lesions in Lyme disease: Isolation of the causative agent. Int J Dermatol 1992;31:507-508.

13. Waniek C, Prohovnik I, Kaufman MA, Dwork AJ. Rapidly progressive frontal-type dementia associated with Lyme disease. J Neuropsychiatry Clin Neurosci. 1995 Summer;7(3):345-7.

* Some studies had both CLD-U and CLD-T patients. 